\title{
Expedition 311 summary
}

\author{
Expedition 311 Scientists $^{2}$
}

\section{Chapter contents}

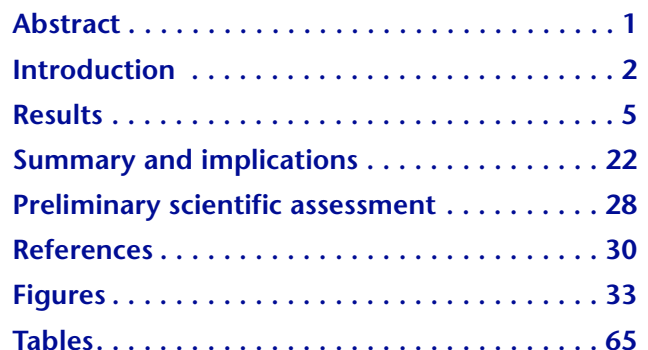

${ }^{1}$ Expedition 311 Scientists, 2006. Expedition 311 summary. In Riedel, M., Collett, T.S., Malone, M.J., and the Expedition 311 Scientists. Proc. IODP, 311: Washington, DC (Integrated Ocean Drilling Program Management International, Inc.). doi:10.2204/iodp.proc.311.101.2006 2Expedition 311 Scientists' addresses.

\section{Abstract}

A transect of four sites (U1325, U1326, U1327, and U1329) across the northern Cascadia margin was established during Integrated Ocean Drilling Program Expedition 311 to study the occurrences and formation of gas hydrate in accretionary complexes. In addition to the transect sites, a fifth site (U1328) was established at a cold vent with active fluid and gas flow.

The four transect sites represent different stages in the evolution of gas hydrate across the margin from the earliest occurrence on the westernmost first accreted ridge (Site U1326) to its final stage at the eastward limit of gas hydrate occurrence on the margin in shallower water (Site U1329).

Logging while drilling and measurement while drilling carried out prior to coring provided a set of measurements that guided subsequent coring and special tool deployments at all five sites. Additional wireline logging at each site and two vertical seismic profiles at Sites U1327 and U1328 were completed. A total of $1217.76 \mathrm{~m}$ of sediment core was recovered using the advanced piston corer and extended core barrel systems. Standard coring was interspersed with 24 (16 successful) pressure core sampler runs for onboard degassing experiments and 19 HYACINTH deployments, of which four were stored under in situ pressure for subsequent shore-based studies.

Indirect evidence of the presence of gas hydrate included increased electrical resistivities and $P$-wave velocities on downhole logs and low-salinity interstitial water anomalies, numerous infrared cold spots, and decreases in void gas $C_{1} / C_{2}$ ratios, as well as gas hydrate-related sedimentological moussy/soupy textures in recovered cores. Gas hydrate was also observed directly in the recovered cores, and $>31$ gas hydrate samples were preserved in liquid nitrogen for shore-based studies. The combined observations show that gas hydrate at these sites mainly occurs within coarsergrained turbidite sands and silts.

The occurrence of gas hydrate appears to be controlled by several key factors, and the concentration of gas hydrate changes significantly as those factors vary in the sediments along the margin. The key controlling factors are

- Local methane solubility linked with pore water salinity,

- Fluid/gas advection rates, and 
- Availability of suitable host material (coarsegrained sediments).

In the previous model for gas hydrate formation in an accretionary margin, the highest concentrations of gas hydrate were expected to occur near the base of the gas hydrate stability zone (GHSZ) above the bottom-simulating reflector (BSR), with concentrations gradually decreasing upward as a result of pervasive fluid advection from tectonically driven fluid expulsion. However, the results of Expedition 311 show that this model is too simple and that there are additional controlling factors. Although evidence for widespread gas hydrate-related BSRs was observed in the data, by far the largest concentrations of gas hydrate were observed at the top of the gas hydrate occurrence zone, at a point where the amount of methane in the pore fluid exceeded the local methane solubility threshold. This condition was most evident at Sites U1326 and U1327, where gas hydrate was observed in sections several tens of meters thick at a shallow depth of $\sim 100$ meters below seafloor (mbsf); concentrations exceed $80 \%$ of the pore volume. Another site of very high gas hydrate concentrations was the cold vent Site U1328, where beds containing massive forms of gas hydrate occurred within the uppermost $\sim 40 \mathrm{~m}$ with concentrations exceeding $80 \%$ of the pore space as a result of focused fluid/gas migration from underneath.

\section{Introduction}

The area of investigation for Expedition 311 is the accretionary prism of the Cascadia subduction zone (Fig. F1). The Juan de Fuca plate converges nearly orthogonally to the North American plate at a present rate of $\sim 45 \mathrm{~mm} / \mathrm{y}$ (e.g., Riddihough, 1984). Seaward of the deformation front, the Cascadia Basin consists of pre-Pleistocene hemipelagic sediments overlain by rapidly deposited Pleistocene turbidites for a total sediment thickness of $\sim 2500 \mathrm{~m}$. Most of the incoming sediment is scraped off the oceanic crust and folded and thrust upward to form elongated anticlinal ridges with elevations as high as $700 \mathrm{~m}$ above the adjacent basins. The thrust faults near the deformation front penetrate nearly the entire sediment section (Davis and Hyndman, 1989).

The primary objective of Expedition 311 is to constrain geologic models for the formation of gas hydrate in subduction zone accretionary prisms. This expedition follows the goals for gas hydrate drilling as proposed by the Ocean Drilling Program (ODP) Gas Hydrates Program Planning Group:

- Study the formation of natural gas hydrate in marine sediments.
- Determine the mechanism of development, nature, magnitude, and global distribution of gas hydrate reservoirs.

- Investigate the gas transport mechanism, and migration pathways through sedimentary structures, from site of origin to reservoir.

- Examine the effect of gas hydrate on the physical properties of the enclosing sediments, particularly as it relates to the potential relationship between gas hydrate and slope stability.

- Investigate the microbiology and geochemistry associated with gas hydrate formation and dissociation.

The specific objectives of this expedition were to test gas hydrate formation models and constrain model parameters, especially those that account for the formation of concentrated gas hydrate occurrences driven by upward fluid and methane transport. These objectives require (1) high-quality data on the concentration, vertical distribution, and regional variation of gas hydrate and free gas in the accretionary prism and (2) estimates of the vertical fluid advection and methane fluxes through the sediment section as a function of landward distance from the deformation front.

The study concentrates on the contrast between methane transport by dispersed pervasive upward flow and focused flow in fault zones. The pervasive permeability may be on the sediment grain scale, on a centimeter scale (the scaly fabric observed in previous ODP clastic accretionary prism cores [Westbrook, Carson, Musgrave, et al., 1994]), or in closely spaced faults.

Natural gas hydrate occurs in marine continental slope and onshore Arctic permafrost environments. Arctic gas hydrate can have very high concentrations but appears to contain less total gas than marine gas hydrate occurrences. Gas hydrate and underlying free gas produce the ubiquitous bottom-simulating reflectors (BSRs) along numerous continental margins of the world. Gas hydrate does occur on passive margins, but is less common and appears to be present at lower concentrations.

The two marine gas hydrate areas that have received the most detailed scientific study, including previous drilling during the ODP, are the Blake Ridge region off the east coast of the United States (a passive margin setting) and the Cascadia margin off the coast of Oregon and Vancouver Island (a subduction zone accretionary prism). Important new information on Arctic gas hydrate occurrences has been obtained from the Mallik-1998 and Mallik-2002 drilling projects in northern Canada (Dallimore et al., 1999; Dallimore and Collett, 2005). If our conclusions for 
the occurrence and distribution of gas hydrate are correct, gas hydrate formed within accretionary prisms is the most important for understanding both the geologic controls on the occurrence of gas hydrate and the role that natural gas hydrate plays in the global carbon cycle.

Within accretionary prisms, the largest amount of gas hydrate is predicted to occur in a widespread layer located just above the BSR (Hyndman and Davis, 1992). However, recent data document the importance of focusing a portion of the upward methane flux into localized migration conduits or channels to form concentrated near-seafloor gas hydrate accumulations. In comparison to the amount of gas hydrate in the widespread layer above the BSR, local concentrations near the seafloor are especially important for understanding the response of the marine gas hydrate reservoir to climate change. Nearseafloor gas hydrate accumulations respond more quickly to ocean temperature changes than gas hydrate that occurs several hundred meters below the seafloor. For the region of ODP Sites 889/890, Taylor et al. (2002) calculated that a $30 \mathrm{~m}$ thick hydrate deposit lying at the base of the stability field would dissociate in response to seabed warming in $\sim 8000 \mathrm{y}$. However, near-seafloor gas hydrate could dissociate much more quickly and be much more responsive to human-induced global warming (e.g., Wood et al., 2002).

Off Vancouver Island a gas hydrate-related BSR occurs in a $30 \mathrm{~km}$ wide band parallel to the coast beneath much of the continental slope (Fig. F1). Gas hydrate is thought to be concentrated in a 50-100 m thick layer above the base of the gas hydrate stability field, which is interpreted to be 200-300 meters below seafloor (mbsf). The gas hydrate concentrations, estimated from downhole logging data collected during ODP Leg 146 , may reach $\sim 30 \%$ of the pore space. The surveys and studies conducted and the evidence for the presence and content of gas hydrate are summarized in two review articles (Hyndman et al., 2001; Spence et al., 2000).

Gas hydrate concentrations were previously estimated from downhole acoustic and resistivity logs, multichannel seismic (MCS) data, vertical seismic profile (VSP) velocities, and pore water freshening (e.g., Yuan et al., 1996, 1999; Hyndman et al., 1999). Gas hydrate concentrations determined from the different methods vary slightly but were estimated to be $20 \%-35 \%$ of the pore space over a $100 \mathrm{~m}$ thick interval above the BSR. Such high concentrations of marine gas hydrate have not been observed on other margins. ODP drilling and logging at the Blake Ridge, offshore South Carolina (a passive margin environment), showed gas hydrate concentrations that were on average $<10 \%$ (Paull, Matsumoto, Wallace, et al., 1996). Results from Leg 204 at southern Hydrate Ridge located on the southern Cascadia margin offshore Oregon, with a very similar tectonic environment to offshore Vancouver Island, indicated very low gas hydrate concentrations of $<5 \%$, except for the unusual summit of Hydrate Ridge (Tréhu et al., 2004). An earlier approach by Ussler and Paull (2001) for interpreting chlorinity data from Leg 146 by using a smooth chlorinity baseline suggested lower gas hydrate concentrations at Sites 889/890 but apparently contradicted geophysical results using electrical resistivity and seismic velocity. In preparation for Expedition 311, the gas hydrate concentrations along the northern Cascadia margin were recalculated using Leg 146 acoustic/electrical resistivity logs and pore water chlorinity/salinity data (Riedel et al., 2005). New estimates show that the concentrations could alternatively be, on average, between $5 \%$ and $10 \%$ of the pore volume from $~ 130$ mbsf to the BSR ( 230 mbsf).

No conclusive decision can be made using interstitial water chlorinity data from Leg 146 to assess the occurrence of gas hydrate without a more complete analysis of the baseline chlorinity data to confirm the model by Torres et al. (2004a) derived from Leg 204 results. Therefore, gas hydrate concentrations along the northern Cascadia margin estimated from chlorinity data may either be as low as a few percent, as suggested by Ussler and Paull (2001), or as high as $40 \%$, as previously suggested by Hyndman et al. (1999). Gas hydrate concentrations were also calculated from resistivity data using Archie's equation. Archie's equation consists of several empirical parameters (referred to as $a, m$, and $n$ ), which were determined to be $a=1.4, m=1.76$, and $n=1.0$ by Hyndman et al. (1999) using the Leg 146 core data at Sites 888 and 889/890. However, Collett (2000) redefined these parameters to $a=1.0, m=2.8$, and $n=1.9$ by using the Site 889 resistivity and neutron porosity logs. The differences in these empirical parameters result in highly different estimates of gas hydrate concentration. The Leg 146 logging data are of relatively poor quality and neither the new parameters nor the previous analyses fit all data well; thus, a large uncertainty remains in the results. However, results from Leg 204, obtained from a tectonically similar environment, suggest that the Archie parameters by Collett (2000) may be preferable.

Finally, new reference velocity profiles were calculated from the Site 889 porosities using various published empirical relations between porosity and velocity (Jarrard et al., 1995; Hyndman et al., 1993) and the Lee et al. (1993) weighted equation. All the newly proposed baselines are significantly shifted to- 
ward higher seismic velocities relative to the former baseline defined by Yuan et al. (1996) and Hyndman et al. (2001). The new estimates result in gas hydrate concentrations that are between $5 \%$ and $10 \%$ of the pore volume. However, significant uncertainty remains in the applicability of the empirical parameters for each of the individual equations. If the model by Torres et al. (2004a) proposed for Hydrate Ridge (Leg 204) is applicable to Site 889 and if the Archie parameters by Collett (2000) are correct, these two methods (although individually uncertain) confirm results from the acoustic velocity analyses of Lee et al. (1993). Thus, the total gas hydrate concentration at Sites $889 / 890$ may be much lower than previously assumed.

A general model for gas hydrate formation by removal of methane from upwardly expelled fluids did exist for the Expedition 311 area (Fig. F2) (Hyndman and Davis, 1992). Mainly microbial methane, inferred to be produced over a thick sediment section, migrates vertically and forms gas hydrate when it enters the stability field. The gas hydrate concentration is predicted to be greatest just above the BSR. A model has also been proposed for how free gas and the resulting BSR will be formed as the base of gas hydrate stability moves upward as a result of postPleistocene seafloor warming, uplift, and sediment deposition (e.g., Paull and Ussler, 1997; von Huene and Pecher, 1998). In addition, physical and mathematical models have been developed for the formation of gas hydrate from upward methane advection and diffusion (e.g., Xu and Ruppel, 1999).

Recently, evidence for focused fluid/gas flow and gas hydrate formation has been identified on the Vancouver margin. The most studied site is an active cold vent field associated with near-surface gas hydrate occurrences close to Site 889 (e.g., Riedel et al., 2002). Studies include high-resolution subbottom profiling, three-dimensional (3-D) seismic surveys, piston coring, and ocean-bottom video surveying and sampling with the remotely operated vehicle ROPOS. These vents are associated with fault-related conduits for focused fluid and/or gas migration associated with massive gas hydrate formation within the fault zone and represent, therefore, the opposite mechanism to the widespread fluid flow. At this time, it is unknown how important these cold vents are in the total budget of fluid flow in an accretionary prism. Drilling at the vent field will help constrain the significance of fault-related fluid flow.

During Expedition 311, a series of four holes was drilled along a margin-perpendicular transect (Figs. F3, F4) representing different stages in the evolution of the GHSZ. An additional fifth site was established to examine an apparent active cold vent.
At the southwestern end of the transect, Site U1326 (proposed Site CAS-03C) (Collett et al., 2005) is located on top of the first uplifted ridge, followed by Site U1325 (proposed Site CAS-02C) located in the first slope-sediment basin. The third site, U1327 (proposed Site CAS-01B), is located near Leg 146 Site 889. The fourth site of the transect, Site U1329 (proposed Site CAS-05D), represents the eastward limit of the gas hydrate occurrence on the margin. The additional fifth site is located at an active cold vent (Site U1328; proposed Site CAS-06A).

Recently acquired bathymetry data revealed a collapse structure near the originally proposed primary Site CAS-03B (Fig. F5). We decided to switch Site CAS-03C from alternate to primary status to avoid coring directly into the slump feature because we expected a more complicated geologic history.

The original proposal, 553-Full2 "Cascadia Gas Hydrate," included long-term monitoring experiments using an Advanced Circulation Obviation Retrofit Kit (ACORK), modular formation dynamic testing (MDT), and distributed temperature sensing (DTS). An extra site for a dual-hole hydrogeologic ACORK experiment was proposed near Site 889 (proposed Site CAS-01C). With a shortened expedition approach limited by the schedule of IODP Phase 1, the long-term monitoring experiments were postponed until a second (yet unscheduled) expedition. Other components of the original proposal that had to be deferred included coring, wireline logging, and logging-while-drilling operations at proposed Sites CAS04B and CAS-05B and a walk-away VSP at proposed Site CAS-01B.

At each site we tried to accomplish a three-hole conventional coring, specialized coring, and logging approach to maximize the scientific objectives. The first hole (Hole A) was always dedicated to loggingwhile-drilling and measurement-while-drilling (LWD/MWD) operations. All LWD/MWD holes were drilled within the first week of the expedition and were followed by coring and conventional wireline operations. The second hole (Hole B) in most cases was for continuous coring, temperature measurements, and pressure core sampler (PCS) coring to establish complete downhole profiles of gas hydrate proxies (such as chlorinity, infrared images, etc.). The third hole (Hole C), when included, was dedicated to special tool deployments, especially the two HYACINTH pressure coring systems, the Fugro Pressure Corer (FPC) and HYACE Rotary Corer (HRC), and additional PCS pressure coring.

During this expedition, we conducted LWD/MWD operations prior to coring each site. It was essential to know before deploying the available pressure core systems what the gas hydrate vertical distribution 
was to properly choose the optimum depths for pressure coring operations. The LWD/MWD data were monitored to detect gas entering the hole as a safety precaution because the LWD/MWD holes were drilled prior to coring. The standard method of hydrocarbon safety management during IODP is core gas ratio measurements. The primary measurement used during Expedition 311 for gas monitoring during LWD/MWD operations was the annular pressure while drilling (APWD) measured by the EcoScope tool in the borehole annulus (the space between the drill string and the borehole wall) (see "Downhole logging" in the "Methods" chapter). On the basis of a calculation of the effect of free gas on the borehole fluid density, it was determined that a pressure decrease of $>100$ psi from the general trend of fluid pressure indicates a significant amount of gas had been released into the drilling fluid, requiring preventative action. For example, a pressure decrease of 100 psi corresponds to $25 \%$ gas saturation in a borehole drilled to $300 \mathrm{mbsf}$. Sudden pressure increases of $>100$ psi were also monitored as possible precursors to gas flow into the annulus (Aldred et al., 1998). Figure F6 shows the results for LWD/MWD APWD measurements acquired during the expedition. For the entire LWD/MWD operations, no APWD response deviated from the baseline by $>30$ psi; therefore, no corrective actions were required under the adopted LWD/MWD safety protocol. The observed positive APWD excursions were all caused by drilling-related difficulties, such as an increase in pumping rates during drilling hard intervals or cuttings restricting flow in the annulus. Interestingly, small negative excursions noted below the BSR (e.g., Site U1328) were associated with a loss in coherence of the sonic waveforms acquired by the SonicVISION tool and may be the result of the presence of free gas.

\section{Results}

\section{Site U1325}

Site U1325 (proposed Site CAS-02C) is located near the southwestern end of the margin-perpendicular transect established during Expedition 311 and is within a major slope basin that developed eastward of the deformation front behind a steep ridge of accreted sediments (Figs. F3, F4). Bathymetry data show that the seafloor in the western part of this slope basin is relatively flat. Around Site U1325, the seafloor $(\sim 1200 \mathrm{~m})$ becomes gradually shallower before it rises rapidly to the east where it forms the plateau of the second main accreted ridge, on which Sites U1327, U1328, and 889 are located. A BSR is clearly visible in the eastern part of the slope basin (Fig. F7), but it fades to the west (common depth points [CDPs] 1180-1280 along MCS Line 89-08). At Site U1325, the BSR is weaker than it is at the core of a buried ridge of accreted sediments located $\sim 700 \mathrm{~m}$ west of this site. The BSR appears to be at $\sim 230 \pm 5$ mbsf based on seismic traveltime-depth conversion, using an average $P$-wave velocity of $1636 \mathrm{~m} / \mathrm{s}$. This average velocity was determined at Site 889 to match observed traveltime depths of the BSR and VSP data (MacKay et al., 1994). We acknowledge that this velocity may not be appropriate in this setting. However, lack of good control in seismic interval velocities from MCS semblance analyses of Lines 89-08 and PGC9902_ODP_7 prohibited accurate depth migration. The BSR also shows the typical frequencydependent reflection strength pattern (Chapman et al., 2002) with reduced reflector strength in higherfrequency seismic data (see Fig. F4 in the "Site U1325" chapter).

The primary research objectives for this site are linked to the transect-concept of the expedition. The objectives include

- Studying the distribution of gas hydrate,

- Defining the nature of the BSR,

- Developing baseline geochemical and microbiological profiles, and

- Obtaining data needed to ground-truth remotely acquired imaging techniques such as seismic or controlled-source electromagnetic (CSEM) surveys.

The slope basin is expected to show a different geochemical regime and related geophysical properties than the uplifted ridges of accreted sediments. A summary of major logging and core data is shown in comparison with two key seismic data sets (coincident but of different seismic frequency) in Figures F8 and F9.

Four holes were occupied at Site U1325. Hole U1325A was dedicated to the LWD/MWD program to a total depth (TD) of $350 \mathrm{mbsf}$ (Table T1). Hole U1325B was spudded with the advanced piston corer (APC) system, but problems arose because of thick sand accumulation, causing a switch to the extended core barrel (XCB) for one core and a switch back to APC. The hole was advanced by combination of $\mathrm{APC}, \mathrm{XCB}$, and pressure coring to $206.5 \mathrm{mbsf}$. Interspersed with the XCB cores was a Davis-Villinger Temperature Probe (DVTP) run at 150.2 mbsf, which yielded high-quality temperature data. Five pressure cores were deployed in Hole U1325B, but all attempts failed to retrieve sediments under pressure. The last run with the PCS resulted in a stuck tool, which led to abandonment of the hole. Hole $\mathrm{U} 1325 \mathrm{C}$ was drilled to $188.8 \mathrm{mbsf}$, the depth where core recovery in Hole U1325B began to deteriorate. 
Coring operations resumed with the XCB system, interspersed with two pressure cores (one failed FPC run and one successful PCS run) and two DVTP deployments, deepening the hole to a TD of 304.3 mbsf. Because of degrading weather conditions, we decided that two separate logging runs would be attempted without calipers to reduce the potential risk of damage to the tool strings. The first run included the phasor Dual Induction Tool (DIT) and the Hostile Environment Gamma Ray Sonde (HNGS). The second run included the Dipole Sonic Imager (DSI), the Scintillation Gamma Ray Tool (SGT), and the Temperature/Acceleration/Pressure (TAP) tool. We were only able to lower the first tool string to 259.8 mbsf (44.5 $\mathrm{m}$ shallower than total depth for coring). The hole was successfully logged, followed by some difficulty reentering the drill pipe. The second tool string (sonic without the Formation MicroScanner [FMS]) was deployed but was only able to reach 185.8 mbsf. The available hole was logged successfully. The repeat pass of the sonic tool string reached 183.0 mbsf. To ensure that a mudline core was obtained at this site, Hole U1325D was established with an APC core (4.69 m recovery), which indicated a seafloor depth of 2193.2 meters below sea level (mbsl; 2204.8 meters below rig floor [mbrf]). Analyses of the pore water showed that the first core in Hole U1325C missed the mudline by $\sim 3 \mathrm{~m}$.

Examination of diatoms from Holes U1325B and U1325C indicated that the sediments cored at Site U1325 are mostly Quaternary in age. The $304.3 \mathrm{~m}$ thick sedimentary section at Site U1325 was divided into four lithostratigraphic units based on visual inspection of the recovered cores and mineralogy data from X-ray diffraction (XRD) analyses of smear slides (Fig. F7).

Lithostratigraphic Subunit IA (0-24.00 mbsf in Hole U1325B and 0-4.69 mbsf in Hole U1325D) is characterized by very abundant, thick, coarse-grained sand layers within fine-grained (clay and silty clay) detrital interlayers. The thickness of the sand layers suggests the depositional environment of a distributary channel within the slope basin with mass transport parallel to the uplifted bounding ridges. The sedimentation rate for the upper $129 \mathrm{~m}$ of sediments (lithostratigraphic Units I, II, and upper part of Unit III) is estimated at $43 \mathrm{~cm} / \mathrm{k} . y$. , the highest sedimentation rate calculated for any Expedition 311 site. Lithostratigraphic Subunit IB (24.00-52.23 mbsf in Hole U1325B) is composed of fine-grained (clay to silty clay) detrital sediments with few thin silty/ sandy interlayers from turbidites. The occurrence of only marine diatoms suggests that terrigenious sediment flux was somehow restricted. In addition, the occurrence of abundant bioturbation and sulfide mottles suggests more hemipelagic-dominated sedimentation. Mousselike texture related to the presence of gas hydrate is seen at depths as shallow as 42.63 mbsf. The boundary between lithostratigraphic Subunits IA and IB is an unconformity marked by a seismic horizon (unconformity) that can be traced for $\sim 1.5 \mathrm{~km}$ around Site U1325 (Fig. F7). It separates undeformed seafloor-parallel slope sediments from underlying deformed and slightly faulted sediments.

Lithostratigraphic Unit II (52.23-102.30 mbsf in Hole U1325B) is characterized by fine-grained (clay to silty clay) detrital sediments with intervals of silty/sandy interlayers. We interpret the coarser interlayers as turbidite deposits. Their frequent occurrence might indicate times of active tectonism. The boundary between lithostratigraphic Units I and II is marked by the absence of diatoms, bioturbation, less intense sulfide mottles, and a sharp decrease in the occurrence of sponge spicules. Mousselike texture related to the presence of gas hydrate was also observed in lithostratigraphic Unit II.

Lithostratigraphic Unit III (102.30-197.40 mbsf in Hole U1325B and 188.80-198.40 mbsf in Hole $\mathrm{U} 1325 \mathrm{C}$ ) is characterized by fine-grained (clay to silty clay) detrital sediments with abundant sponge spicules and diatoms. We interpret this interval as mixed hemipelagic-turbidite sediments. The presence of unlithified authigenic carbonate cement suggests that diagenetic processes are active in lithostratigraphic Unit III. Soupy and mousselike sediment textures related to the presence of gas hydrate are present in lithostratigraphic Unit III within the depth interval from $\sim 121$ to $\sim 145$ mbsf. The boundary between lithostratigraphic Units III and IV is marked by the sudden decrease in diatoms.

Lithostratigraphic Unit IV (197.40-206.56 mbsf in Hole U1325B and 198.40-299.17 mbsf in Hole $\mathrm{U} 1325 \mathrm{C}$ ) is characterized by fine-grained (clay to silty clay) detrital sediments with few silty/sandy interlayers from turbiditic deposits. The poor recovery in this unit limits the observation of sedimentary structures; however, the appearance of several coarser-grained layers indicates low-energy turbidity currents. Mousselike sediment textures were observed to $\sim 242$ mbsf.

The stratigraphic section logged at Site U1325 was divided into three logging units based on obvious changes in the LWD/MWD and wireline gamma ray, density, electrical resistivity, and acoustic measurements. There is no obvious correlation between the logging units and lithostratigraphic units.

Logging Unit 1 (0-122 mbsf) is characterized by a well-defined gradual increase in density with depth 
and a corresponding decrease in porosity. This increase in density is matched by a corresponding increase of resistivity with depth, from $\sim 1 \Omega \mathrm{m}$ near the seafloor to $\sim 1.5 \Omega \mathrm{m}$ at $122 \mathrm{mbsf}$. The boundary between logging Units 1 and 2 corresponds to the 0.3 Ma age biostratigraphic boundary.

Logging Unit 2 (122-250 mbsf) is characterized by a uniform density that averages $\sim 1.9 \mathrm{~g} / \mathrm{cm}^{3}$. In contrast, the resistivity logs in Unit 2 show alternating thin intervals of high and low resistivity, spanning the range 1-15 $\Omega \mathrm{m}$. These high and low resistivities likely correspond to intercalated layers that have high and low gas hydrate concentrations, respectively.

Logging Unit 3 (250-350 mbsf) displays uniform background resistivity $(\sim 1 \Omega \mathrm{m})$ and density $(\sim 2 \mathrm{~g} /$ $\left.\mathrm{cm}^{3}\right)$. The most striking feature of this unit is the presence of several borehole enlargements.

LWD/MWD-derived resistivity-at-the-bit (RAB) images from Hole U1325A suggest that gas hydrate was concentrated in thin sand layers within the interval between 173 and 240 mbsf (logging Unit 2). The LWD/MWD porosity and resistivity logs from Hole U1325A further show that it is a very heterogeneous gas hydrate-bearing section composed of alternating layers of gas hydrate-saturated sands and clay-rich layers with little to no gas hydrate. This interpretation is in general agreement with the marked freshening of the interstitial waters observed in sampled sand layers.

There appears to be little correlation between the core-derived physical property data and defined lithostratigraphic or logging units. Sediment density and porosity determined from moisture and density (MAD) analyses show a typical sediment compaction trend with depth. Slight deviations in the density and porosity profiles with depth reflect small-scale lithologic variability and generally match the downhole measured LWD/MWD data. Infrared (IR) imaging of the recovered cores was routinely carried out on the catwalk to detect and characterize the nature of gas hydrate in the cores. A large number of IRimaged cold spots were detected in the cores from Holes U1325B and U1325C and were partially subsampled for focused interstitial water analyses and microbiology studies. In many cases the IR-imaged cold temperature anomalies correlated with layers of high resistivity and low interstitial water salinities and chloride concentrations, which reflect gas hydrate dissociation during core recovery.

Six deployments of temperature tools were attempted at Site U1325, and all six provided usable data. Three APC3 and one DVTP deployment in Hole U1325B, as well as two additional DVTP deploy- ments in Hole U1325C, occurred during times of relatively low heave and yielded high-quality data. A linear fit to the points indicates a thermal gradient of $0.060^{\circ} \pm 0.003^{\circ} \mathrm{C} / \mathrm{m}$ and a seafloor intercept of $3.03^{\circ}$ $\pm 0.55^{\circ} \mathrm{C}$. If a hydrostatic pore pressure gradient and seawater salinity are assumed, the temperature data indicate that the base of the GHSZ for this site is 275 \pm 25 mbsf.

Pressure coring tools were deployed seven times at Site U1325, including two PCS cores, two HRC cores, and one FPC core in Hole U1325B. Hole U1325C included one FPC core from above the projected depth of the BSR and one PCS core from below the predicted depth of the BSR. Pressure coring proved to be extremely difficult at Site U1325. Only the deepest PCS deployment (Core 311-U1325C-10P; 256.5 mbsf) successfully recovered core under pressure, which was investigated by a controlled shipboard degassing experiment. All other attempts to deploy pressure cores failed for various reasons (e.g., the presence of unconsolidated fine sand and the potential effect of adverse ship heave conditions). Degassing of Core 311-U1325C-10P yielded $2.07 \mathrm{~L}$ of methane gas and may have contained small amounts of gas hydrate $(0.4 \%)$ or free gas $(0.3 \%)$, depending on where the base of gas hydrate stability (BGHS) is situated (see uncertainty in temperaturederived BGHS above).

A total of 92 interstitial water samples were processed from two holes cored at Site U1325. The salinity and chlorinity profiles at this site appear to indicate an advective transport system with the occurrence of higher than seawater salinity and chlorinity ( $\sim 36$ and $600 \mathrm{mM}$, respectively), which likely comes from a deeper source. The chlorinity of this fluid is $7.3 \%$ above the modern seawater value, more than twice the interglacial salinity increase (3.5\%). The elevated solute concentration may be caused by low-temperature diagenetic hydration reactions in the deeper parts of the basin. The most plausible candidate for such a reaction is alteration of volcanic ash to clay minerals and/or zeolites. In the zone extending from $\sim 70$ to 240 mbsf (the BSR is at $230 \pm 5$ mbsf), salinity and chlorinity data show discrete excursions to fresher values, indicating that gas hydrate was present in the cores and dissociated prior to processing the samples. Intense microbial activity at Site U1325 results in sulfate depletion, phosphate and alkalinity production, and significant $\mathrm{Ca}$ and $\mathrm{Mg}$ depletion in the interstitial waters of the upper 3 mbsf. At this site the sulfate/methane interface (SMI) was between 4 and 5 mbsf, based on samples recovered from Hole U1325D (see Fig. F32).

Organic geochemical studies at Site U1325 included analysis of the composition of volatile hydrocarbons 
$\left(\mathrm{C}_{1}-\mathrm{C}_{5}\right)$ and nonhydrocarbon gases (i.e., $\mathrm{O}_{2}$ and $\mathrm{N}_{2}$ ) from headspace gas samples, void gas samples, and gas samples recovered during the PCS degassing experiment. With the exception of several samples that contained a large percentage of air, the void gas was almost entirely methane with a small percentage of carbon dioxide $(\sim 0.1 \%-0.5 \%)$. Trace quantities of $\mathrm{C}_{2+}$ hydrocarbons $(<5 \mathrm{ppmv})$ were present above the predicted BSR depth (230 mbsf). With greater depth, the concentrations of ethane, propane, and isobutane increased but did not exceed $15 \mathrm{ppmv}$. The molecular ratios of methane to ethane $\left(C_{1} / C_{2}\right)$ were the highest observed during Expedition 311. $C_{1} / C_{2}$ values from where gas voids were first observed (9.1 mbsf) to the predicted BSR depth ranged from $\sim 61,000$ to $\sim 173,000$ and showed no apparent trend with depth. Decreasing $C_{1} / C_{2}$ values below the BSR indicate a slight thermogenic or diagenic contribution of ethane.

Microbiological subsampling was routinely conducted on cores recovered from Holes U1325B and U1325C. On each core run, perfluorocarbon tracer (PFT) was continuously metered into the drilling fluid and fluorescent microspheres were deployed to investigate potential drilling fluid contamination of the core. These analyses confirmed that the center of each APC core and XCB biscuit remain undisturbed and suitable for microbiological analyses. Additional IR images were taken on the cut ends of each microbiological core section to document the thermal warming process of the core before subsampling.

Seismic data (Fig. F7) suggest that the sediments cored at Site U1325 are similar to those seen in a seafloor-parallel package of sediments on the southwest side of the buried accreted ridge, but they have been deformed and tilted with small offset faults associated with the uplift of the underlying ridge. Enhanced advective fluid flow from the buried accreted basin resulted in gas hydrate formation within the overlying deformed section, preferentially in the coarser-grained turbidite sequences. In contrast, the southwest part of the basin has relatively little deformation. The postulated reduced fluid flow and therefore limited gas hydrate accumulation also explains the lack of a strong BSR in that part of the basin.

Although the BSR is not very prominent near Site U1325, the stratigraphic section beneath the projected BSR generally shows high-amplitude reflectors and updip amplitude truncations at the BSR, typical of free gas trapped beneath the BSR. Data from downhole logging and coring also reveal lateral homogeneity between the holes at this site, which is a testament to the orientation of the holes along structural strike in a northwest-southeast direction, avoid- ing the steep southwest-northeast-dipping slope seen in the seismic data. Except for difficulties with pressure coring and temperature deployments, all objectives for Site U1325 were fulfilled.

\section{Site U1326}

Site U1326 (proposed Site CAS-03C) is located on an uplifted ridge of accreted sediments at the southwest end of the multisite transect established during Expedition 311 (Fig. F4). Recently acquired bathymetry data reveal a collapse structure near the originally proposed primary Site CAS-03B, which may have complicated the recent geologic history of this site (Fig. F5). Site CAS-03C was designated as the primary site to avoid coring the slump feature.

The headwall of the slump feature near proposed Site CAS-03B is $\sim 250 \mathrm{~m}$ high and the slump has eroded a $\sim 2.5 \mathrm{~km}$ long section into the ridge. Further examination of the bathymetry data from this area also reveals the occurrence of continuous linear features crossing the ridge in an almost east-west direction. These linear features are clearly associated with faults as seen on Figure F10. The outcrop of these faults at the seafloor generate a surface displacement of as much as $25 \mathrm{~m}$ and can be seismically traced from the surface through the sedimentary section to depths below the BSR. The occurrence of these deep throughgoing faults is generally limited to the area of the slump scar. The seismic character of the ridge also changes from the southwest to the northeast across the ridge, with the southwest-facing part of the ridge characterized by strong semicontinuous reflectivity (Figs. F11, F12), whereas the seismic reflectivity disappears underneath the northeast-facing flank of the ridge. The differences in the seismic character across the ridge cannot be easily explained, and it is one of the research focuses of the site. The BSR is present underneath most of the ridge (Fig. F10), but it is almost absent underneath the slump feature in association with the most heavily faulted sediments.

The objectives of coring and logging at this site are tied to our goal of understanding processes along the transect of scientific research holes drilled across the northern Cascadia margin. Site U1326 is the closest location to the deformation front. It probably represents the tectonically youngest occurrence of gas hydrate on the northern Cascadia margin and as such, our primary research objectives include

- Studying the distribution of gas hydrate,

- Defining the nature of the BSR,

- Developing baseline geochemical and microbiological profiles, and 
- Obtaining data needed to ground-truth remotely acquired imaging techniques such as seismic or CSEM surveys.

The operational plan to achieve these objectives was based on a general three-hole concept, which included an LWD/MWD logging hole, a continuous core hole to characterize geochemical and microbiological processes, including generation of proxies for the occurrence gas hydrate, and an additional "tool" hole for specialized pressure coring and selected spot-coring using conventional systems. The special tools hole was also intended to be logged with the conventional IODP wireline logging tool strings.

After transiting from Site U1325, the LWD/MWD bottom-hole assembly (BHA) was tripped to the seafloor. Hole U1326A was spudded at $1445 \mathrm{~h}$ on 22 September 2005 at an estimated seafloor tag depth of 1828.1 mbsl (1839.0 mbrf). To avoid blowing out the top of the hole, we adopted a controlled-spud program that featured reduced drilling fluid circulation rates of only $100 \mathrm{gpm}$ and a bit rotation rate of 10$15 \mathrm{rpm}$. As the hole was advanced, both the circulation rate and bit rotation rate were increased to maintain a $50 \mathrm{~m} / \mathrm{h}$ rate of penetration. The LWD/ MWD safety protocol was followed without incident and required no corrective action. After drilling the hole to a TD of $300 \mathrm{mbsf}$, the drill string was pulled clear of the seafloor at $0600 \mathrm{~h}$ on 23 September. Hole U1326B was spudded $15 \mathrm{~m}$ northeast of Hole $\mathrm{U} 1326 \mathrm{~A}$ at $1205 \mathrm{~h}$ on 23 October. The first core failed to establish the depth of the mudline, so a new hole (U1326C) was spudded without offsetting from the location of Hole U1326B at 1245 h on 23 October. The first core established a seafloor depth of 1828.0 mbsl (1839.6 mbrf). On the fourth APC core ( 30 mbsf), we unexpectedly hit APC refusal and switched to XCB coring. Hole U1326C was advanced by XCB coring to $82.7 \mathrm{mbsf}$ and followed by three consecutive pressure core deployments within a high-electrical resistivity zone identified on LWD/ MWD downhole logs. In this case, the FPC and HRC pressure core runs were added to the traditional continuous core hole. The FPC was the first pressure core system deployed at this site and recovered a partial core $(15 \mathrm{~cm})$ under pressure. The second system deployed was the PCS, which also recovered a partial core under pressure. The third pressure core system deployed was the HRC, which was "packed off" with sand. Consequently, the cutting shoe and the lower part of the autoclave were unscrewed and left in the hole, resulting in the termination of Hole U1326C at a TD of 86.7 mbsf (Table T1). After tripping the BHA back to the seafloor, the ship was moved $\sim 30 \mathrm{~m}$ southwest (15 m from Hole U1326A). Hole U1326D was spudded at $1130 \mathrm{~h}$ on 24 October and drilled to
78.8 mbsf in preparation for continued coring to a target depth of 300 mbsf. Because of problems associated with the sea state and schedule limitations, all pressure coring operations were suspended. XCB coring deepened the hole to $271.4 \mathrm{mbsf}$. With the forecast of deteriorating weather conditions on the morning of 26 October, we decided to stop coring and drill the hole to 300 mbsf. Despite the marginal conditions, we attempted three deployments with the DVTP (252.2, 271.4, and 300 mbsf), which yielded degraded data. After completing coring and drilling operations, we decided to conduct a single downhole logging run with a nonstandard IODP tool string, which included the SGT, DIT, and the DSI. At $2315 \mathrm{~h}$ on 26 October, the logging tool string was lowered to $298.4 \mathrm{mbsf}$ and two successful logging passes were made, with the tool string back on deck at $0345 \mathrm{~h}$. The drill string was pulled clear of the seafloor at $0530 \mathrm{~h}$ on 27 October, ending operations in Hole U1326D.

The 271.40 m thick Quaternary sedimentary section cored at Site U1326 was divided into three lithostratigraphic units (Fig. F13). Lithostratigraphic Unit I (0-1.50 mbsf in Hole U1326B and 0-24.13 mbsf in Hole U1326C) is characterized by fine-grained (clay to silty clay) detrital sediments with thin silty/sandy interlayered turbidite sequences. Foraminifers, bivalve shell fragments, sponge spicule remains, mottling, bioturbation, and a high marine versus nonmarine diatom ratio indicate hemipelagic sedimentation mixed with turbiditic inputs (coarsegrained facies). Unlithified authigenic carbonate cement is also present in lithostratigraphic Unit I.

Lithostratigraphic Unit II (24.13-82.70 mbsf in Hole U1326C and 88.40-146.30 mbsf in Hole U1326D) is also dominated by fine-grained (clay to silty clay) detrital sediments with intervals of turbidite deposits (silty/sandy interlayers), but diatoms are absent and other biogenic components are rare. The frequent occurrence of turbidites might indicate times of active tectonism. Below 30.4 mbsf, abundant soft-sediment deformation and dipping strata show that tectonism is more active at the westernmost end of the transect drilled during this expedition. Unlithified authigenic carbonate cement and lithified carbonate are also present in lithostratigraphic Unit II. Soupy and mousselike textures indicative of gas hydrate occurrence were observed in this unit starting at $\sim 52$ mbsf. The lithostratigraphic Unit II/III boundary is marked by a low abundance of diatoms and the beginning of coring-related biscuiting.

Lithostratigraphic Unit III (146.30-271.40 mbsf in Hole U1326D) is characterized by fine-grained (clay to silty clay) detrital sediments with few thin silty/ sandy turbidite interlayers. We interpret this interval 
as mixed hemipelagic-turbiditic deposition. Soupy sediment textures related to the presence of gas hydrate are also present in lithostratigraphic Unit III to 246 mbsf.

Precoring LWD/MWD logging was conducted at Site U1326 to direct special tool deployments, such as collecting PCS, HRC, and FPC pressure cores. The stratigraphic section logged at Site U1326 was divided into three "logging units" based on obvious changes in LWD and wireline gamma ray, density, electrical resistivity, and acoustic measurements. The three identified logging units do not correspond to the defined lithostratigraphic units.

Logging Unit 1 (0-72 mbsf in Hole U1326A) is characterized by a resistivity trend that steadily increases from $\sim 1 \Omega \mathrm{m}$ near the seafloor to $\sim 1.5 \Omega \mathrm{m}$ at the bottom of the unit. The increase in resistivity with depth is matched by an increase in density. This unit shows only a few small resistivity "spikes" (e.g., at $\sim 52$ and 60 mbsf in the LWD logs) that may be attributed to gas hydrate.

Logging Unit 2 (72-240 mbsf in Hole U1326A) is characterized by uniform density with depth and includes a prominent high-resistivity section from 72 to $107 \mathrm{mbsf}$ in Hole U1326A, with peaks $>40 \Omega \mathrm{m}$. This interval of high resistivity also includes a number of alternating thin intervals of very low resistivities. These high and low resistivities likely correspond to intercalated layers that have high and low gas hydrate concentrations, respectively. The $P$-wave velocities measured by wireline logging in Hole U1326D show highly variable values (between 1750 and $>3000 \mathrm{~m} / \mathrm{s}$ ) in the same high-resistivity interval. The high values of $P$-wave velocity are consistent with high concentrations of gas hydrate.

The top of logging Unit 3 (240-300 mbsf in Hole U1326A) is marked by an increase in density, which remains constant to 300 mbsf. The background resistivity also increases slightly and displays a clear peak, reaching $5 \Omega \mathrm{m}$ in the interval 255-261 mbsf. This resistivity peak could be caused by gas hydrate or free gas. Free gas seems more likely, as this interval is located below the expected BSR depth at this site, estimated from seismic reflection data at 234 mbsf. On the other hand, $P$-wave velocities are at least 1700 $\mathrm{m} / \mathrm{s}$ in this unit and there is no sign of the low velocities expected in a free gas zone.

LWD/MWD-derived RAB images from Hole U1326A also indicate the presence of gas hydrate in the highresistivity interval observed in logging Unit 2. Gas hydrate-rich layers alternate with low-resistivity layers that likely contain little or no gas hydrate (Fig. F13). Closer examination of the RAB images also shows apparent stratigraphic layers in the interval from 50 to 300 mbsf, uniformly dipping to the north-northeast with dips between $45^{\circ}$ and $85^{\circ}$. This is in agreement with the west-northwest-east-southeast strike of the uplifted ridge penetrated by Hole U1326A.

The Archie calculation of water saturations from electrical resistivity logging data yield evidence for relatively shallow gas hydrate occurrences at this site between $~ 50$ and 100 mbsf, with inferred gas hydrate concentrations as high as $80 \%$ of the pore space (Fig. F13). This interpretation is in general agreement with the freshening of pore waters observed in sand layers at Site U1326. The IR core images taken on the catwalk revealed cold anomalies caused by gas hydrate dissociation, which give an independent map of gas hydrate occurrence and concentrations. In some cases, IR-imaged cold temperature anomalies correlate with layers of high resistivity. In other cases, however, cold intervals in the IR images are harder to correlate to high-resistivity peaks in the wireline or LWD/MWD logs because of incomplete core recovery and intrasite geologic variability.

Cold temperature anomalies were observed from 70 to $250 \mathrm{mbsf}$, and catwalk sampling was conducted based on these scans. Many interstitial water samples were taken from the cold temperature anomalies to extend the chlorinity anomaly database available for calibrating IR data as a proxy for gas hydrate saturation. We note that the maximum depth of observed IR anomalies is deeper than the anticipated BSR depth of 234 mbsf. It is also suggested that the chlorinity anomaly associated with gas hydrate may actually extend to a depth as great as 270 mbsf at this site. This apparent conflict between the predicted depth of the BSR and the observed occurrence of gas hydrate can be further explored with closer examination of gas hydrate stability conditions at this site. Because of difficult weather conditions during coring operations at this site, we deployed only four temperature tools. For the most part, data from the temperature tool deployments were degraded. At this time, we have extrapolated the temperature data from Site U1325 to estimate downhole temperatures at Site U1326. A predicted GHSZ depth of $275 \pm 25$ mbsf is estimated and would explain most of the deeper IR and chlorinity inferred gas hydrate occurrences.

At Site U1326, only one PCS core (Core 311-U1326C$12 \mathrm{P} ; 83.7 \mathrm{mbsf}$ ) was recovered under pressure and investigated by controlled shipboard degassing experiments. The degassing of this single PCS core yielded 19.1 L of methane, equivalent to a pore space gas hydrate saturation of $40 \%$, which is in close agreement with the gas hydrate saturations estimated from the 
LWD/MWD Archie resistivity calculations in the that interval.

Microbiological subsampling was routinely conducted on cores recovered from Holes U1326C and U1326D. On each core run, perfluorocarbon tracer (PFT) was continuously metered into the drilling fluid and fluorescent microspheres were deployed to investigate potential drilling fluid contamination of the core. These analyses confirmed that the center of each APC core and XCB biscuit remains undisturbed and suitable for microbiological analyses. Additional IR images were taken on the cut ends of each microbiological core section to document the thermal warming process of the core before subsampling.

Considering its location within the westernmost portion of the deformation front, we selected this site to further characterize what could be the tectonically youngest gas hydrate occurrence on the northern Cascadia margin. Hydrocarbon headspace gas measurements from Holes U1326C and U1326D show that methane is the dominant hydrocarbon gas within the cored interval at this site. Although the $\mathrm{C}_{2+}$ hydrocarbon void gas concentrations were $<125$ ppmv for all samples, their relative abundances and distribution were valuable for describing the gas hydrate system at Site U1326. Low $\mathrm{C}_{1} / \mathrm{C}_{2}$ ratios within the interval from $\sim 35$ to $\sim 72$ mbsf were associated with two recovered gas hydrate samples. With greater depth, ethane concentrations returned to the near-surface concentrations close to the predicted depth of the BSR. Isobutane concentrations were also elevated within the same interval, which may indicate the presence of Structure II gas hydrate. The occurrence of more complex hydrocarbon gases generally indicates contribution of a deeper gas source. The salinity and chlorinity profiles at this site also point to a deeper fluid source with a chloride concentration higher than seawater, indicative of lowtemperature diagenetic reactions in the deeper parts of the site. Except for the difficulties experienced with pressure coring and special temperature tool deployments, all of the objectives set for Site U1326 were fulfilled.

\section{Site U1327}

Site U1327 (proposed Site CAS-01B) is located near Sites 889/890, approximately at the midslope of the accretionary prism over a clearly defined BSR estimated at 223 mbsf (Figs. F14, F15). The primary research objectives for this site are linked to the transect concept of this expedition. Sites 889/890 provided critical baseline data for the development of the objectives of this expedition. The concentration of gas hydrate in sediments from Sites 889/890 (ODP Leg 146) have been estimated by using (1) de- viations in interstitial water chlorinities, (2) electrical resistivity measurements by applying Archie's relation, and (3) both seismic- and downhole loggingderived $P$ - and $S$-wave velocities. Many questions were left unanswered (Riedel et al., 2005), such as:

- What is the geochemical reference profile for chlorinity and other geochemical gas hydrate proxies?

- What is the electrical resistivity baseline for the sediments drilled at this site and what are the appropriate empirical Archie coefficients?

- What are the reference profiles for acoustic $P$ - and $S$-wave velocities?

Answers to these questions are needed to calibrate remote sensing techniques, such as reflection seismic and CSEM surveys, which can be obtained through research coring and downhole logging.

Five holes were occupied at Site U1327 (Table T1). Hole U1327A (TD = $300 \mathrm{mbsf}$ ) was dedicated to LWD/MWD measurements. Initially we planned to drill to $350 \mathrm{mbsf}$, but the short time allocated for LWD/MWD operations made it necessary to reduce the depth of the planned penetration at this site. The first APC core in Hole U1327B missed the mudline with a full core. The core was curated and a new hole was spudded without offsetting the ship. Hole U1327C was cored (10 APC cores, 22 XCB cores, and 3 PCS cores; recovery $=88.3 \%$ ) to 300.0 mbsf. The PCS was deployed three times in Hole U1327C, and four advanced piston corer temperature (APCT) tool measurements were made (Cores 311-U1327C-3H, $5 \mathrm{H}, 7 \mathrm{H}$, and $9 \mathrm{H})$. Three additional deployments using the DVTP and Davis-Villinger Temperature-Pressure Probe (DVTPP) were attempted, but data quality is marginal because of strong heave and instrument failures. In Hole U1327D, which was drilled and cored as a special tools hole, two APC cores were taken from the surface to $16.4 \mathrm{mbsf}$ for a high-resolution microbiological and geochemical study of the SMI. In this hole, the PCS was deployed three times, the HCR was deployed four times, and the FPC system was deployed twice. The last pressure core was taken at 246.0 mbsf before advancing the hole to a TD of 300 mbsf for the logging program.

The first tool string deployed was the triple combination (triple combo), which reached 295.4 mbsf. The hole was logged to $\sim 70$ mbsf without incident, except for a damaged caliper arm. The VSP logging program in Hole U1327D was successfully carried out with 16 clamping stations covering the depth range from 181 to 276 mbsf before the arm on the Well Seismic Tool (WST) broke. The WST was returned with some difficulty to the ship. Because of the critical nature of the acoustic logging data to the expedi- 
tion, we decided to drill a new hole and acquire additional pressure cores and a wireline acoustic log.

Hole U1327E was advanced to $3 \mathrm{mbsf}$, and a single $9.5 \mathrm{~m}$ long APC core was taken for high-resolution microbiological and geochemical sampling of the SMI, which had been missed during an earlier attempt. Two additional PCS cores and one HRC core were taken, but only the second PCS deployment at 80.0 mbsf recovered sediment under pressure. Excessive heave $(>3.5 \mathrm{~m})$ forced the termination of pressure coring operations, and the hole was advanced by drilling to a TD of 300 mbsf for the second wireline logging run. Because of excessive heave conditions, we decided to run a nonstandard tool string devoid of any protruding arm (HNGS-DIT-DSI), which allowed measurement of natural gamma radiation, resistivity, and acoustic data $\left(V_{\mathrm{p}}\right.$ and $\left.V_{\mathrm{s}}\right)$. Two successful runs of this tool string recovered highquality downhole logging data.

Site U1327 is located near two prominent topographic highs composed almost entirely of accreted sediments rising $>200 \mathrm{~m}$ above the surrounding seafloor (Fig. F14). The ridges of accreted sediment lack any coherent seismic reflections and are associated with underlying thrust faults that contributed to the overall uplift of the area between the two ridges (Westbrook, Carson, Musgrave, et al., 1994; Riedel, 2001). Site U1327 is near the northwest flank of the easternmost ridge and is characterized by a $\sim 90 \mathrm{~m}$ thick cover of slope-basin sediments underlain by a thick section of accreted sediments (Fig. F15). The stratigraphy at Site U1327 was divided into three lithostratigraphic units (Figs. F15, F16).

Lithostratigraphic Unit I (0-90.1 mbsf in Hole U1327C; age = Holocene(?)-Pleistocene; $<0.3 \mathrm{Ma})$ is composed of dark greenish gray and dark gray clay and silty clay, often interbedded with silt, clayey silt, sandy silt, sand, and gravel layers. Unit I is characterized by fine-grained detrital sediments (clay and silty clay) with abundant coarse-grained layers as much as $6 \mathrm{~cm}$ thick that indicate turbidite deposits and a sedimentation rate of $22 \mathrm{~cm} / \mathrm{k} . \mathrm{y}$. Unlithified authigenic carbonate cement is present in Unit I, but no evidence for dolomite precipitation was found, which is inferred from interstitial water analyses. A unique characteristic of Unit I is the anomalous occurrence of lithified carbonates and rocks of various lithologies (e.g., granite), which probably are dropstones from rafting icebergs. The lithostratigraphic boundary between Units I and II is marked by a sharp decrease in sand and silt layers and the onset of diatom-rich sediments. It is also the seismically inferred boundary between slope-basin type and accreted sediments (Fig. F15).
Lithostratigraphic Unit II (90.1-170.4 mbsf in Hole $\mathrm{U} 1327 \mathrm{C}$; age = Pleistocene; $>0.3-1.0 \mathrm{Ma}$ ) is composed of dark greenish gray and dark gray clay, clay with diatoms, and silty clay, silty clay with diatoms, and diatom silty clay locally interbedded with sandy silt and sand layers and lenses. Very few unlithified carbonate cements are present in Unit II, but lithified carbonates and exotic rocks (some as much as 4 $\mathrm{cm}$ in diameter) similar to those described in Unit I are very abundant in some cores, especially between 142 and 148 mbsf in Hole U1327C and 151 and 157 mbsf in Hole U1327D. Within Unit II, soupy and mousselike sediment textures related to the presence of observed gas hydrate can be correlated to IRimaged cold spot anomalies detected on the catwalk. The sedimentation rate of Unit II is estimated at $~ 16$ $\mathrm{cm} / \mathrm{k} . \mathrm{y}$., and the intervals with a high ratio of nonmarine versus marine diatoms indicate an increased contribution of terrigeneous detrital sediments from land sources by turbidites. The great abundance of marine diatoms along with resting spores within lithostratigraphic Unit II suggest deposition beneath a coastal upwelling shelf environment followed by reworking by turbidity currents.

Lithostratigraphic Unit III (170.4-TD in Hole $\mathrm{U} 1327 \mathrm{C}$; age = Pleistocene; $>1 \mathrm{Ma})$ is composed of dark greenish gray and dark gray silty clay in the upper part of the unit, whereas the lower part (below 248 mbsf) is dark greenish gray silty clay with diatoms. Unit III is distinguished from Unit II by the sudden absence of diatoms, as well as the degree of induration of the sediments. Diatoms reappear at the bottom of Unit III. Few unlithified carbonate cements are present and lithified carbonates and exotic rock clasts were found, especially within Core 311U1327C-24P (197.3 mbsf). The depositional environment for Unit III was interpreted to have been dominated by low-energy turbidity currents in an abyssal plain. The biostratigraphically determined sedimentation rate in this section is low $(\sim 12 \mathrm{~cm} / \mathrm{k} . \mathrm{y}$.$) and is$ consistent with a basin-plain setting.

The downhole logged section at Site U1327 was divided into three logging units based on obvious changes in the LWD/MWD and wireline gamma ray, density, electrical resistivity, and acoustic measurements. There is no apparent correlation between the logging units and lithostratigraphic units at this site.

Logging Unit 1 (0-120 mbsf) is characterized by a resistivity trend that steadily increases from $\sim 1 \Omega \mathrm{m}$ near the seafloor to $\sim 2 \Omega \mathrm{m}$ at the bottom of the unit. $P$-wave velocities in this unit average $\sim 1550 \mathrm{~m} / \mathrm{s}$.

Logging Unit 2 (120-240 mbsf) is characterized by a constant background resistivity value of $\sim 2 \Omega \mathrm{m}$ and relatively high $P$-wave velocities (as much as 2000 $\mathrm{m} / \mathrm{s}$ ) over most of the interval. This unit shows a 
number of thin (0.5-1.0 m thick) high-resistivity sections that may be attributed to gas hydrate. The occurrence of relatively high downhole measured $P$ wave velocities in these same intervals also indicates the presence of gas hydrate. A thick section of consistently high electrical resistivities and $P$-wave velocities and low density measurements was observed in the LWD/MWD data at 120-138 mbsf in Hole U1327A. This section was the target of several pressure cores in adjacent holes (see below for details). It was later determined, however, that this high-resistivity zone was laterally discontinuous. It was penetrated in adjacent Holes U1327C and U1327D at a much greater depth (ranging from 20 to $35 \mathrm{~m}$ deeper) and was not intersected in Hole U1327E.

The top of logging Unit 3 (240-300 mbsf) is defined by a sharp decrease in $V_{\mathrm{p}}$ and $V_{\mathrm{s}}$. Below $240 \mathrm{mbsf}, V_{\mathrm{p}}$ decreases to low values near fluid velocities $(\sim 1500$ $\mathrm{m} / \mathrm{s}$ ), which suggests the presence of small amounts of free gas. Unit 3 also displays a small drop in resistivity compared to Unit 2 . Although resistivity tends to be just above $2 \Omega \mathrm{m}$ in Unit 2 , it is just below $2 \Omega \mathrm{m}$ in Unit 3.

Variations in the core-derived physical properties do not correlate well with the identified lithostratigraphic and logging units, with the exception of the boundary between lithostratigraphic Units I and II, which is marked by a sharp increase in magnetic susceptibility. Sediment density and porosity determined from MAD analyses show a typical trend with depth, suggesting normal compaction. Slight deviations from this trend reflect small-scale lithologic variability and generally match the porosity and density trend determined from the LWD/MWD data.

IR imaging of the recovered cores was routinely carried out on the catwalk to detect and characterize the nature of gas hydrate in the cores. A large number of IR-identified cold spots were detected in the cores from Holes U1327C and U1327D. Mismatches between the IR-inferred gas hydrate occurrences in Holes U1327C and U1327D and the logging resistivity-inferred gas hydrate occurrences in Holes U1327A, U1327D, and U1327E document the lack of lateral continuity at this site. In situ temperature measurements with the APCT, DVTP, and DVTPP3 (Table T2) suggest a geothermal gradient of $\sim 59^{\circ} \mathrm{C} /$ $\mathrm{km}$, which is not significantly different from that estimated for Site $889\left(\sim 54^{\circ} \mathrm{C} / \mathrm{km}\right)$.

The PCS was deployed eight times at Site U1327 (three times in Hole U1327C, three times in Hole U1327D, and twice in Hole U1327E) (Table T3). Five deployments recovered sediment under pressure. In addition to the PCS deployment, the HRC was used four times (three cores recovered under pressure) and the FPC was used twice, but only one was recovered under pressure. Degassing of the five PCS cores recovered under pressure showed variable gas concentrations with depth. The deepest PCS core was recovered from 246.0 mbsf, which is $\sim 25 \mathrm{~m}$ below the anticipated depth of the BSR. This pressure core (Core 311-U1327D-17P) had a pore space methane concentration of $209 \mathrm{mM}$, which is equivalent to a free gas concentration in the sediment pore space of $1.0 \%$. The other four PCS cores were taken from within the predicted depth interval of the GHSZ. Core 311-U1327E-3P, the shallowest (80.0 mbsf) PCS core taken from this site, yielded $0.91 \mathrm{~L}$ of methane $(83 \mathrm{mM})$ or, equivalently, $0.2 \%$ gas hydrate concentration. The remaining three PCS cores were taken at 121.8, 155.7, and 197.3 mbsf (Core 311-U1327C-15P yielded 1.1 L [96 mM] of methane; Core 311U1327D-10P yielded $9.4 \mathrm{~L}$ [674 $\mathrm{mM}]$ of methane; and Core 311-U1327C-24P yielded 4.1 L [253 mM] of methane). Core 311-U1327D-10P yielded enough gas to infer an average gas hydrate pore space concentration of $\sim 8 \%$. The other two PCS cores yielded gas hydrate pore space concentrations ranging from $0.2 \%$ to $1.8 \%$.

Three HRC cores (Cores 311-U1327D-4E at 125.3 mbsf, 12E at $170.5 \mathrm{mbsf}$, and $14 \mathrm{E}$ at $217.7 \mathrm{mbsf}$ ) and one FPC core (13Y at $203.6 \mathrm{mbsf}$ ) were successfully recovered and transferred under pressure to storage chambers for shore-based analyses. These cores were imaged with $\mathrm{X}$-ray and logged for $P$-wave velocity and density within their storage vessels. High $P$-wave velocities and anomalous low density readings indicate the recovered pressure cores contained gas hydrate.

High-resolution interstitial water sampling was carried out to characterize the SMI, which was determined to be located between 9 and 10 mbsf (see Fig. F32). An overall smoothly decreasing trend in pore water chlorinity and salinity is observed, similar to results from Sites 889/890 (Westbrook, Carson, Musgrave, et al., 1994). From 128 mbsf to the depth of the BSR the chlorinity and salinity profiles exhibit distinct anomalies that likely indicate freshening as a result of the dissociation of gas hydrate during the core recovery process (Fig. F16). Chloride values as low as $70 \mathrm{mM}$ (salinity = 3.7) from two samples correlated to sand layers (as much as $3 \mathrm{~cm}$ thick) that also showed IR cold spot anomalies. Such a low pore water chlorinity is equivalent to a pore space gas hydrate concentration of $\sim 80 \%$. No chlorinity anomalies occur below $225 \mathrm{mbsf}$, which is close to predicted depth of the BSR. The strongly decreasing chlorinity profile from the surface to below the BSR at Site U1327 suggests mixing between in situ seawater and modified deep-sourced pore water, which 
is relatively fresh fluid. Interstitial water chlorinity and salinity remain almost constant beneath the BSR.

Organic geochemical studies at Site U1327 included analysis of the composition of volatile hydrocarbons $\left(\mathrm{C}_{1}-\mathrm{C}_{5}\right)$ and nonhydrocarbon (i.e., $\mathrm{O}_{2}$ and $\mathrm{N}_{2}$ ) gases from headspace gas samples, void gas samples, and gas samples recovered during PCS degassing experiments. The predominant hydrocarbon gas found in the cores from Site U1327 was methane; however, we did see an increase in ethane concentrations in the void and headspace gases collected from the stratigraphic section overlying the projected depth of the BSR. The increase in ethane concentrations near the BSR is reflected in the $\mathrm{C}_{1} / \mathrm{C}_{2}$ void gas ratios (Fig. F16), which decrease with depth toward the BSR. Other studies have shown that dissociation of ethane enriched gas hydrate can depress void gas $\mathrm{C}_{1} /$ $\mathrm{C}_{2}$ ratios. In general, the $\mathrm{C}_{1} / \mathrm{C}_{2}$ ratios were high $(>1000)$, indicating mostly a microbial origin for the observed methane.

Microbiological subsampling was routinely conducted on cores recovered from Hole U1327C. On each core run, PFT was continuously metered into the drilling fluid, and fluorescent microspheres were deployed on selected cores to investigate potential drilling fluid contamination. Additional IR images were taken on the cut ends of each microbiological core section to document the thermal warming process of the core before subsampling.

The primary research objectives of this site are linked to the results from Sites 889/890 of Leg 146 to delineate critical geochemical, geophysical, and microbiological data for gas hydrate proxy analyses. Site U1327, along with Sites $889 / 890$, is the center of a research study area that has been the focus of many interdisciplinary gas hydrate studies since 1992 .

Geochemical analyses of recovered gas samples and interstitial fluids documented a relatively complex fluid regime for this site, similar to what was observed at Sites 889/890 and U1329. The rapid chlorinity concentration decrease with depth strongly suggests fluid communication with a deep-seated, fresher fluid source. Earlier interpretations of the chlorinity profile measured at Sites $889 / 890$ attributed $\sim 60 \%$ of the pore water freshening to gas hydrate dissociation upon core recovery (Hyndman et al., 1999). However, the new interstitial water data collected at Site U1327, in combination with other gas hydrate proxy data (such as IR images and downhole logging measurements), strongly support the development of a new undisturbed baseline for interstitial water chlorinity along the northern Cascadia margin that decreases with depth in the manner suggested by Ussler and Paull (2001). Based on IR and chlorinity fluctuations, gas hydrate-related pore water freshening at Site U1327 is interpreted to be limited to the interval from $\sim 110$ to 225 mbsf. The hydrocarbon gas data suggest the presence of gas hydrate above the BSR and a deep source of thermogenic gases, which supports similar conclusions drawn from the interstitial water data.

Identifying gas hydrate and constraining its relative abundance in combination with providing physical models for the BSR were the critical objectives for this site. A suite of geophysical experiments was conducted including precoring LWD/MWD logging, conventional wireline logging, and VSP to characterize the physical properties of gas hydrate-bearing sediments. The presence of gas hydrate is generally characterized by increases in measured electrical resistivity and acoustic velocity. The LWD/MWD data from Hole U1327A showed an $18 \mathrm{~m}$ thick zone of increased resistivity and acoustic velocity values combined with a decrease in density, which was interpreted to contain large amount of gas hydrate with concentrations $>50 \%$ of the pore volume. However, the same interval was penetrated in the adjacent core holes, Holes U1327C and U1327D, at much greater depths and with lower estimated gas hydrate concentrations inferred from the wireline electrical logs. No evidence of this interval was found in the wireline log in Hole U1327E. This shows large intrasite variability in gas hydrate content that is probably controlled by lithostratigraphic changes or structural complexities. This observation has dramatic implications on the calibration of geophysical surveying techniques such as seismic methods or CSEM surveys that are commonly used to detect and quantify gas hydrate.

The combined use of IR imaging, interstitial pore water analyses, and void/headspace gas sampling revealed that many IR cold spots identified on the catwalk occur in relatively thin but coarser-grained intervals of sand and/or silty sand (interpreted to represent turbidite deposits) with gas hydrate concentrations in several cases exceeding $80 \%$ of the pore space. The gas hydrate preferentially forms in these coarser-grained sections. Therefore, it is likely that the $18 \mathrm{~m}$ thick LWD/MWD-measured high-resistivity and borehole fluid velocity interval (120$138 \mathrm{mbsf}$ ) in Hole U1327A is a localized feature made up of discontinuous thinly bedded gas hydrate-saturated turbidite sand lenses that appears as a massive single unit when surveyed with a lower vertical resolution logging tool.

The results of the VSP seismic experiment taken in combination with the downhole acoustic logging from Hole U1327E also show a relatively thick zone below the depth of the BSR that probably contains a 
considerable amount of free gas. The acoustic velocity decrease at the BSR is not abrupt; it is more transitional across a $\sim 25 \mathrm{~m}$ thick interval from $>1800 \mathrm{~m} / \mathrm{s}$ in the GHSZ to a velocity as low as $1280 \mathrm{~m} / \mathrm{s}$ in the underlying section. This confirms earlier interpretations of the frequency-dependent reflection behavior of the BSR from vertical incidence seismic data where the BSR was thought to be a gradient zone in which velocity decreases over several meters (Chapman et al., 2002).

This site was intended to characterize the gas hydrate occurrence on the northern Cascadia margin to establish an understanding of the geologic, geophysical, and geochemical controls on the occurrence and abundance of gas hydrate along the five-site transect established during this expedition. All of the objectives set for Site U1327 were fulfilled.

\section{Site U1328}

Site U1328 (proposed Site CAS-06A) is located within a seafloor cold vent field $(2 \mathrm{~km} \times 4 \mathrm{~km})$ consisting of at least four vents associated with near-surface faults. The cold vents are characterized by near-vertical seismic blank (or wipeout) zones that are between 80 and several $100 \mathrm{~m}$ wide and show a clear east-west trend as identified from 3-D seismic imaging. The most prominent vent in the field, referred to as Bullseye vent, was the target of this site and has been the subject of intensive geophysical and geochemical studies since 1999 (e.g., Riedel et al., 2006). Site U1328 is different from all of the other sites visited during this expedition in that it represents an area of active, focused fluid flow. A number of seismic surveys cross this site, including two single-channel seismic (SCS) 3-D surveys and a regional MCS data set. In Figure F17 we show MCS Line XL07 and the main lithostratigraphic units, hole locations, and penetration depths at this site.

Several mechanisms have been proposed to explain the seismic blanking and nature of fluid venting in the Bullseye vent area (Riedel et al., 2002, 2006; Zühlsdorff and Spiess, 2004; Wood et al., 2002). The objectives of coring and logging at this location are to test the different models for the cold vent structure and associated causes of seismic blanking, the rate of methane advection, and potential loss of methane into the water column. It is important to obtain a high-resolution temperature profile for this area to assess any evidence of active fluid flow. Pressure coring using the PCS system will help assess the occurrence of free gas within the GHSZ below Bullseye vent and possibly ascertain the cause of the observed seismic blanking. Additional pressure coring using the HRC and FPC systems was used to recover high-quality gas hydrate-bearing core for shorebased analyses.

Five holes were occupied at Site U1328. Hole U1328A was dedicated to LWD/MWD measurements to a TD of 300 mbsf. Hole U1328B was continuously cored (six APC, two XCB, and two PCS cores; recovery $=72.8 \%$ ) to $56.6 \mathrm{mbsf}$ before strong winds and severe ship heave conditions required us to pull out of the hole. Two APC temperature measurements were made (APCT and APC3). As a calibration experiment, the DVTPP was deployed at the bottom of Hole U1328B. After waiting on weather for $16 \mathrm{~h}$, improved conditions allowed drilling and coring operations to continue. Hole U1328C was drilled from the seafloor to the maximum depth of Hole U1328B (56.5 mbsf). Hole U1328C was continuously cored (4 $\mathrm{APC}$ cores, $22 \mathrm{XCB}$ cores, and 1 PCS core; recovery = $80.7 \%)$ to 300 mbsf. In addition, one APCT, two APC3, and two DVTPP temperature measurements were made. Hole U1328C was wireline logged with the triple combo and FMS-sonic tool strings. The triple combo logged from a TD of 294 mbsf, and two uphole passes of the FMS-sonic tool string logged the same depth interval. The wireline logging program in Hole U1328C included a VSP survey, with the deepest clamping position at 286 mbsf. The VSP included 35 clamping positions, with the uppermost station at 106 mbsf. Hole U1328D was cored as a special high-resolution combined microbiology and geochemistry research hole. Two XCB cores and a single FPC core were taken at the bottom of the hole. Hole U1328E was a special tools hole, which also included the deployment of six XCB cores within the upper $46.0 \mathrm{mbsf}$ to recover additional samples of gas hydrate. Seven pressure cores (three PCS, two HRC, and two FPC) were separated by $\mathrm{XCB}$ cores and drilled intervals. Hole U1328E also included two DVTP deployments for temperature data. In Figures F18 and F19, data from LWD/MWD logging (RAB images, porosity, and Archie-derived pore water saturations), core-derived physical property data (porosity), interstitial water chlorinity, and $\mathrm{C}_{1} / \mathrm{C}_{2}$ ratios from void gas samples are shown in comparison to the two key crossing seismic lines from this site.

At Site U1328, a $300 \mathrm{~m}$ thick sequence of Quaternary ( 0 to $<1.6 \mathrm{Ma}$ ) slope and slope basin sediments was recovered (Fig. F17). The biostratigraphy determined for Site U1328 is based on the examination of diatoms from Holes U1328B and U1328C. The stratigraphic section cored and logged at Site U1328 is divided into three lithostratigraphic units.

Lithostratigraphic Unit I (0-56.98 mbsf in Hole U1328B, 56.98-132.60 mbsf in Hole U1328C, 015.00 mbsf in Hole U1328D, and 0-92.26 mbsf in Hole U1328E) is characterized by fine-grained detri- 
tal sediments (dark greenish gray clay and silty clay) with abundant coarse-grained layers as much as $6 \mathrm{~cm}$ thick indicative of turbidite deposits. The large impact of turbidite deposits is reflected in high sedimentation rates $(37.5 \mathrm{~cm} / \mathrm{k} . \mathrm{y}$.$) . Lithified and/or$ partly lithified carbonates were often found associated with soupy and mousseline sediment textures. The presence of argonite (besides high-Mg calcite) seems to indicate carbonate formation related to the presence of gas hydrate. The boundary between lithostratigraphic Units I and II is marked by a sharp decrease of sand and silt layers and by the onset of diatom-bearing sediments.

Lithostratigraphic Unit II (132.60-197.10 mbsf in Hole U1328C and 197.00-198.00 mbsf in Hole $\mathrm{U} 1328 \mathrm{E}$ ) is characterized by fine-grained (clay to silty clay) detrital sediments with some silty interlayers from turbiditic deposits and siliceous fossils (sedimentation rate $=24.6 \mathrm{~cm} / \mathrm{k} . \mathrm{y}$.). Abundant marine diatoms along with resting spores of Chaetoceros in lithostratigraphic Unit II suggest the diatoms bloomed in a shallow-water shelf environment associated with coastal upwelling and were then reworked. The boundary between lithostratigraphic Units II and III is distinguished by the sudden absence of diatoms.

Lithostratigraphic Unit III (197.10-300.00 mbsf in Hole U1328C) is characterized by fine-grained (clay to silty clay) detrital sediments with very few silty interlayers from turbidite deposits, likely deposited in an abyssal plain environment. The presence of unlithified authigenic carbonate cements show that diagenetic processes are active in Unit III.

At Site U1328, gas hydrate was sampled and evidence of gas hydrate was found in the recovered cores in the form of soupy and mousselike textures. At this site, soupy texture is only present within Unit I and mousselike textures are present occasionally within Units I to III.

The LWD/MWD and wireline logged section in Holes U1328A and U1328C was divided into three logging units based on changes in the downhole measured gamma ray, density, electrical resistivity, and acoustic measurements. For the most part, these logging units correspond closely to lithostratigraphic Units I, II, and III.

Logging Unit 1 (0-128 mbsf in Hole U1328A) is characterized by a well-defined increase in density with depth. The most striking feature in this unit is seen in the LWD/MWD logs between the seafloor and 46 mbsf, where high resistivities $(>25 \Omega \mathrm{m})$ alternate with intervals of much lower resistivity (1-2 $\Omega \mathrm{m})$. The high resistivities likely indicate the presence of gas hydrate, which were sampled during coring.
Logging Unit 2 (128-200 mbsf in Hole U1328A) is marked at the top by a clear decrease in density log values. Unit 2 is also characterized by a constant and relatively low background resistivity value just above $1 \Omega \mathrm{m}$. Only one significant high-resistivity log-inferred gas hydrate interval occurs at a depth of 160 mbsf.

Logging Unit 3 (200-300 mbsf in Hole U1328A) is characterized by small increases in background resistivity and notably more variability in the resistivity and $P$-wave velocity $\log$ values.

Physical properties were measured in cores recovered from four of the holes at this site. Core-derived MAD data compare favorably to both the LWD/MWD and downhole wireline data. Numerous low-porosity outliers, however, were interpreted to represent sand-rich samples.

It has been shown that RAB images derived from the LWD/MWD GeoVISION tool can be used to identify gas hydrate distribution in sediment (Tréhu, Bohrmann, Rack, Torres, et al., 2003). High concentrations of gas hydrate are evident in the interval 0-46 mbsf of Hole U1328A, where resistivities are high. The RAB images from Hole U1328A also reveal numerous high-resistivity sinusoidal features in the upper 46 mbsf in Hole U1328A and again at 90-100 mbsf, which can be interpreted as dipping fractures containing gas hydrate or possibly free gas. These near-vertical fractures may act as gas migration conduits that feed the gas hydrate accumulation observed near the seafloor.

The GeoVISION-derived resistivity logs were used as input to the Archie relation to estimate the amount of gas hydrate at Site U1328. These calculations show highly variable gas hydrate saturations in the upper $46 \mathrm{mbsf}$, with values as high as 95\% in several intervals up to $10 \mathrm{~m}$ thick. These layers of high gas hydrate concentrations alternate with layers of much higher water saturations.

The combined analysis of acoustic velocities and waveform amplitudes can also help identify the occurrence of gas hydrate and/or free gas. In the interval between 210 and 220 mbsf, near the predicted depth of the BSR at $\sim 219 \mathrm{mbsf}$, the $P$-wave velocity drops slightly while the $S$-wave velocity increases. This could be due to the coexistence of free gas and gas hydrate in the vicinity of the BSR, which has been observed on Blake Ridge and Hydrate Ridge. Additional evidence for the occurrence of free gas below the BSR was noted in the analysis of the LWD/ MWD acoustic coherence data, borehole fluid pressure response during drilling, and the wireline $P$ wave, resistivity, density, and neutron logs. The PCS degassing experiments of a single core in Hole 
U1328E also indicate the presence of a free gas phase below the BSR at this site (see below). However, it is important to note that the VSP survey obtained in Hole U1328C yielded a very uniform velocity profile with depth and no clear velocity contrast around the expected depth of the BSR.

We deployed the APCT, APC3, DVTP, and DVTPP temperature tools a total of ten times, but recorded only three reliable data points because of severe ship heave conditions (Table T2). The in situ temperatures determined for Site U1328 are generally similar to those at Site U1327 and slightly higher than those determined at similar depths during Leg 146. For Site U1328 we obtained a seafloor temperature of $\sim 3.5^{\circ} \mathrm{C}$ and a geothermal gradient of $\sim 54^{\circ} \mathrm{C} / \mathrm{km}$, which corresponds to a predicted depth to the base of the GHSZ ranging from 222 to 247 mbsf given the uncertainty in the data.

All cores from this site were systematically scanned on the catwalk to detect IR anomalies indicative of gas hydrate dissociation during core recovery. Strong cold anomalies were detected in the shallowest cores from this site. Our recovery of a large amount of gas hydrate in the upper $30 \mathrm{mbsf}$ was anticipated based on LWD/MWD resistivity measurements and previous piston coring at this site (Riedel et al., 2002, 2006; Solem et al., 2002). However, the LWD/MWD high resistivity-inferred gas hydrate occurrence at 90-100 mbsf in Hole U1328A was not seen on either the IR images or the wireline logs in Hole U1328C. The IR data may have missed this interval due to poor core recovery, but the lack of a high-resistivity layer in the wireline log points to horizontal inhomogeneity. This is not unexpected, in that the highresistivity layer in the LWD/MWD image contains a steeply dipping fracture that is unlikely to be intersected at the same depth even in two closely spaced holes. The strongest anomalies were detected just above the predicted BSR depth (210-222 mbsf), and a few small but distinct cold anomalies were observed below it, one of which exhibited pore water freshening indicative of the presence of gas hydrate (Core 311-U1328C-22X; 247 mbsf). The possibility of gas hydrate beneath the BSR may indicate the presence of Structure II gas hydrate, which is stable below the base of the pure methane Structure I GHSZ. However, it should be noted that substantial uncertainty remains in the exact depth of the base of the gas hydrate stability field at this site and the depth of the BSR. All available data suggest that the GHSZ could be deeper than the initially inferred depth of the BSR and result in shifting the observed IR anomalies to depths well within the gas hydrate stability field of Structure I gas hydrate.
At Site U1328 we attempted 11 deployments of the 3 different pressure coring tools. The PCS was deployed six times at Site U1328 (twice in Hole U1328B, once in Hole U1328C, and three times in Hole U1328E), five of which recovered sediment under pressure. The HRC was deployed two times and the FPC was deployed three times, but none were recovered under pressure. Degassing of the five successful PCS cores from this site showed variable gas concentrations with depth. Two PCS cores taken within the near-surface gas hydrate-bearing section from 0 to 46 mbsf (Core 311-U1328B-4P at $14.5 \mathrm{mbsf}$ and $7 \mathrm{P}$ at $26.0 \mathrm{mbsf}$ ) yielded 21.5 and $2.5 \mathrm{~L}$ of methane, respectively, which is equivalent to pore volume gas hydrate saturations of $\sim 15 \%$ and $\sim 2 \%$. X-ray images of Core 311-U1328B-4P under pressure show 2-6 $\mathrm{mm}$ thick low-density structures that disappeared after degassing and are interpreted as gas hydrate veins. This core showed large amounts of gas expansion and sediment extrusion during depressurization, as did Cores 311-U1328B-7P and 311U1328E-10P to a lesser extent. The two PCS cores taken in Holes U1328C and U1328E at $92.0 \mathrm{mbsf}$ (Cores 311-U1328C-5P and 311-U1328E-10P) yielded different amounts of methane gas equating to the occurrence of 38\% (Core 311-U1328E-10P) and $0.7 \%$ (Core $311-\mathrm{U} 1328 \mathrm{C}-5 \mathrm{P}$ ) of gas hydrate. One PCS core (Core 311-U1328E-13P) was taken at 233.0 mbsf, very close to the inferred depth of the BSR. This core yielded 59.9 L of methane, the largest recovery of gas during this expedition. This amount of methane would fill 58\% of the pore space if it was present as free gas or 50\% if it was present as gas hydrate. However, gamma ray density scans during degassing and X-ray scans after depressurization showed almost no evidence of gas expansion cracks or large voids in the core. We speculate that most of the gas released during degassing of this core came from the space between the inner and outer core barrel, where a gas bubble was observed during X-raying. Volumetric analysis suggests the presence of a $540 \mathrm{~mL}$ headspace in the outer core barrel, which corresponds well with the $410 \mathrm{~mL}$ volume that would have been occupied by the released amount of gas at in situ conditions. The apparent extra gas in the PCS might have swabbed into the core barrel during the coring process.

A total of 90 interstitial water geochemistry samples were processed from four of the holes cored at Site U1328. The composite chlorinity profile for this site shows four distinct zones. In the upper $\sim 60 \mathrm{mbsf}$, we see a striking increase in chlorinity, with maximum values in the interval between 5 and 20 mbsf exceeding $850 \mathrm{mM}$. The observed excess solutes are interpreted to result from salt exclusion from the water 
lattice structure during in situ gas hydrate formation that has not been removed by advective or diffusive processes. The second zone from $\sim 60$ to $\sim 150 \mathrm{mbsf}$ is characterized by linearly decreasing chlorinity values ranging from 538 to $570 \mathrm{mM}$. A third zone, extending from $\sim 150$ to $250 \mathrm{mbsf}$, across the BSR, shows discrete excursions to fresher chlorinity values (as low as $348 \mathrm{mM}$ ), suggesting that gas hydrate was present in the cores and dissociated prior to processing the samples. The chlorinity anomalies are consistent with observations of distinct negative thermal excursions in IR scans. Our observations further indicate that most of the gas hydrate occupies relatively thin sand layers. In the deepest zone, below 250 mbsf, the chlorinity remains nearly constant at 493 $\pm 3 \mathrm{mM}$, suggesting communication with a fluid at greater depth that is notably different in composition from the deep-seated fluid sampled at Sites U1327 and 889/890.

To form and maintain shallow gas hydrate deposits near the seafloor, methane has to be supplied continuously. Furthermore, the shallow elevated chlorinity values would dissipate rapidly if they were not continuously maintained by ongoing gas hydrate formation. However, the chlorinity profile below 30 mbsf at Site U1328 indicates a diffusion-controlled system. These observations indicate that the methane needed to sustain the shallow gas hydrate formation is likely supplied along faults or fracture zones, probably the ones imaged by the RAB tool within the gas hydrate-bearing section immediately below the seafloor.

The shipboard organic geochemistry program for Site U1328 included analysis of hydrocarbons and nonhydrocarbon gases from headspace gas samples, void gas samples, gas samples recovered during PCS degassing experiments, and gases from gas hydrate samples. Methane was the most prominent hydrocarbon gas in all of the samples analyzed; however, ethane was also present in almost all of the headspace samples. Most of the gas hydrate samples and gas hydrate-bearing sediments collected within the upper 46 mbsf exhibited elevated ethane concentrations. These near-surface samples also contained slightly more air contamination and elevated $\mathrm{H}_{2} \mathrm{~S}$ concentrations. It is also notable that the concentration of ethane and other gas hydrate-forming gases, including propane and isobutane, increase within the gas samples collected from the cores crossing the predicted depth of the BSR, where the chlorinity and IR temperature anomalies both indicate evidence for gas hydrate. The occurrence of propane and elevated isobutane to $n$-butane $\left(i-\mathrm{C}_{4} / n-\mathrm{C}_{4}\right)$ ratio support the suggestion that the gas hydrate near the depth of the BSR contains Structure II gas hydrate. It is also inter- esting that the ethane concentrations remain elevated below the depth of the BSR. Structure II gas hydrate is stable to greater depths with increasing temperature than Structure I gas hydrate; however, the observed IR and chlorinity anomalies are not necessarily below the base of the Structure I gas hydrate stability field and therefore not automatically related to the suggested Structure II gas hydrate given the uncertainty in the temperature measurements. However, the gas geochemistry does suggest the presence of some Structure II gas hydrate near the predicted depth of the BSR.

Microbiological subsampling was routinely conducted on cores recovered from Holes U1328B and U1328C. On each core run PFT was continuously metered into the drilling fluid, and fluorescent microspheres were deployed on all cores in the continuously cored holes to investigate potential drilling fluid contamination. These analyses confirmed that the center of each APC core and XCB biscuit remain undisturbed and suitable for microbiological analyses. Additional IR images were taken on the cut ends of each microbiological core section to document the thermal warming process of the core before subsampling.

The main objectives at this site were to

- Document the depth distribution of gas hydrate and the relationship to fluid and gas chemistry, lithology, and faulting and

- Determine the fluid advection rate feeding the surface vents.

However, only the very shallowest ( $<30 \mathrm{mbsf})$ portion of the sedimentary section cored at Site U1328 is dominated by fluid advection. It appears that diffusion transport controls the chemical depth profiles below 30 mbsf, except perhaps in the deepest $50 \mathrm{~m}$ (250-300 mbsf) where $\mathrm{Cl}$ and salinity data suggest control by advection. This apparent contradiction can be explained with the vent model brought forward by Riedel et al. (2006). The model, based on various geophysical and geochemical observations, predicted that the shallow gas hydrate accumulations are the result of isolated feeder channels or fractures. Along these fractures the bulk of the methane gas is transported upward and results in the near-seafloor concentrated gas hydrate accumulation. Evidence of the existence of these fractures comes from the LWD/MWD downhole logging data showing at several depths steeply dipping resistivity anomalies typical of fractures filled with gas hydrate or possibly free gas. These potential gas migration conduits may be connected to the seafloor chemosynthetic cold vent communities observed by bottom video surveys (Riedel et al., 2002, 2006). 
The growth of gas hydrate near the seafloor has resulted in solute exclusion and development of high pore water salinities. This brine cannot be maintained in situ over a long time period, unless gas hydrate is constantly formed at relatively high rates. The cold vent must be supplied with fluids from greater depth. This is also indicated by the detection of a methane plume in the water column just above an active vent outlet. However, venting is most likely episodic since the methane plume is not always detectable (Riedel et al., 2006). There is further evidence for the presence of Structure II gas hydrate at this site as indicated by the presence of propane and isobutane.

Various geophysical data support the presence of a BSR at this site, as proposed by Riedel et al. (2006); however, the BSR is difficult to identify with the available seismic data. The lack of good 3-D seismic velocity control could potentially result in misinterpretation of the existing two-dimensional (2-D) seismic data, in that the observed BSR may actually be a side diffraction and may not be exactly located beneath the active part of the cold vent and seismic blanking. In the LWD/MWD data a sharp decrease in electrical resistivity was observed at $\sim 220$ mbsf, although it is coincident with a high-density interval potentially related to the presence of carbonates. Acoustic wireline logging, however, shows a sharp discontinuity in $P$-wave and $S$-wave velocity at a depth of $\sim 215 \mathrm{mbsf}$, close to the predicted BSR depth of $219 \pm 2.5$ mbsf. The downhole temperature measurements from this site yielded a temperature gradient of $\sim 54^{\circ} \mathrm{C} / \mathrm{km}$, which predicts the base of gas hydrate stability at $\sim 234.5 \pm 12.5$ mbsf for the observed pore water and gas geochemistries.

There is evidence for the presence of free gas below the predicted BSR depth, as demonstrated from pressure coring, LWD/MWD pressure monitoring, and elevated LWD/MWD electrical resistivity values. There are also seismic indicators for the occurrence of free gas below the BSR in the form of strong amplitude anomalies. However, the VSP does not show any evidence of a velocity change over the entire logged interval from 105 to 285 mbsf, which will be further examined postcruise. Except for difficulties with pressure coring and temperature deployments, all objectives for Site U1328 were fulfilled.

\section{Site U1329}

Site U1329 (proposed Site CAS-05D) is at the eastern end of the southwest-northeast-trending marginperpendicular transect of sites occupied during this expedition and is located closest to shore $(65 \mathrm{~km})$ at a water depth of $\sim 946$ mbsf. The location of this site is believed to be at the eastern limit of gas hydrate occurrence on the northern Cascadia margin.

The objectives of coring and downhole logging at this site are tied to completing the transect of scientific drill sites across the northern Cascadia margin to further constrain models for the formation of marine gas hydrate in a subduction zone accretionary prism. The depth to the BSR rapidly becomes shallower around this site and is only about half the depth ( 126 mbsf) of that at Site U1327 ( 225 mbsf) (Figs. F20, F21). At this eastern end-member site of gas hydrate evolution in the accretionary prism, the objectives include

- Characterizing the distribution of gas hydrate,

- Defining the nature of the BSR,

- Developing baseline geochemical and microbiological profiles, and

- Obtaining data needed to ground-truth remotely acquired imaging techniques such as seismic and CSEM surveys.

Five holes were occupied at Site U1329 (Table T1). Hole U1329A was dedicated to LWD/MWD measurements to a TD of 220 mbsf. Hole U1329B consisted of one missed mudline APC core to 9.5 mbsf. Hole U1329C was continuously cored (17 APC, 5 XCB, and 3 PCS cores; recovery $=99.3 \%$ ) to $189.5 \mathrm{mbsf}$ and was terminated before the TD of 220 mbsf when the PCS cutting shoe broke off in the bottom of the hole. The PCS was deployed three times in Hole U1329C, and four APC temperature measurements were made (APCT and APC3). Swell from a passing low-pressure system resulted in ship heave that was too high for wireline logging or coring operations, and we waited $4 \mathrm{~h}$ for the weather to improve. With a forecast for improving weather the following day, we decided to abandon Hole U1329C to drill a dedicated logging hole. Hole U1329D was drilled from the seafloor to $201.0 \mathrm{mbsf}$, which included another $1.5 \mathrm{~h}$ of suspended operations due to excessive ship heave, and a single XCB core was taken to 210.5 mbsf. Hole U1329D was wireline logged with the triple combo and FMS-sonic tool strings. The triple combo and the first pass of the FMS-sonic were logged to 209 mbsf. The second pass of the FMSsonic only reached 171 mbsf. Hole U1329E was a special tool hole to $127.1 \mathrm{mbsf}$, where five APC cores were taken for high-resolution microbiological and geochemical studies, with two additional APC temperature measurements. Two DVTP deployments were also conducted. Five pressure cores were taken (three PCS, one HRC, and one FPC) separated by drilled intervals. In Figures F22 and F23, data from LWD/MWD logging (RAB images, porosity, and Archie-derived pore water saturations), core-derived 
physical property data (porosity), and interstitial water chlorinity, as well as $\mathrm{C}_{1} / \mathrm{C}_{2}$ ratios from void gas samples are shown in comparison to the two key crossing seismic lines from this site.

Site U1329 is located near the foot of a relatively steep slope, and sedimentation at this site is dominated by slope processes. The stratigraphy at Site U1329 was divided into three lithostratigraphic units.

Lithostratigraphic Unit I (0-37.18 mbsf in Hole U1329C and 0-33.31 mbsf in Hole U1329E) is characterized by fine-grained detrital sediments (clay and silty clay), locally interbedded with coarse-grained sediments. Authigenic carbonates are abundant in some cores from Unit I. Dolomite was observed in Holes U1329C and U1329E at depths that coincide with changes in pore water $\mathrm{Ca}$ and $\mathrm{Mg}$ profiles, suggesting dolomite formation is an ongoing process. The sedimentation rate in Unit I is relatively low at $\sim 10 \mathrm{~cm} / \mathrm{k} . \mathrm{y}$. The boundary between lithostratigraphic Units I and II is defined by the first occurrence of diatom ooze.

Lithostratigraphic Unit II (37.18-135.60 mbsf in Hole U1329C and 33.31-125.95 mbsf in Hole $\mathrm{U} 1329 \mathrm{E})$ is characterized by a high abundance of biogenic silica (mainly diatoms). The sedimentation rate within Unit II appears to increase from $\sim 4$ to 10 $\mathrm{cm} / \mathrm{k} . \mathrm{y}$. The boundary between Units II and III is marked by a conglomerate composed of partly lithified to lithified rounded clasts supported by a silty clay matrix. The conglomerate at the base of Unit II corresponds to an unconformity between upper Miocene and Pleistocene sediments (no sediments preserved from 2-6.7 Ma) that can be traced seismically for several kilometers along Line 89-08 (Fig. F20). The unconformity is not clearly seen in the higherfrequency seismic data Line SCS CAS05C-01-04 (Fig. F21).

Lithostratigraphic Unit III (135.60 mbsf-TD) is characterized by fine-grained (clay to silty clay) detrital sediments with only a few coarser interlayers from turbidite deposits. The input of detrital sediments from turbidites, however, is more obvious deeper in the section with the presence of nonmarine diatoms. In the lowermost part of Unit III, a conglomerate deposit marks a major change in deposition, possibly representing a debris flow. The sediments in Unit III were deposited at a low sedimentation rate of $\sim 0.8$ $2.8 \mathrm{~cm} / \mathrm{k} . \mathrm{y}$.

The biostratigraphy at this site was established by the analysis of diatoms. These analyses showed an interval of Quaternary sediments from the surface to $\sim 35$ mbsf that corresponds to lithostratigraphic Unit I. The age of lithostratigraphic Unit II was shown to range from 0.3 to $2.0 \mathrm{Ma}$. This interval showed an abundance of diatoms and resting spores of Chaetoceros, suggesting a depositional environment typical of a coastal shelf area with upwelling. The sediments of this interval may also have been transported to this site from the shelf by turbidites. Sediments deeper than 137 mbsf, near the contact between lithostratigraphic Units II and III, contain diatoms of only late Miocene age ( $>6.7 \mathrm{Ma}$ ); thus, the Pliocene at this site is completely absent, representing $\sim 4 \mathrm{~m} . \mathrm{y}$. of missing sediment, which was likely eroded.

The downhole logged section at Site U1329 was divided into three logging units based on changes in the LWD/MWD and wireline gamma ray, density, electrical resistivity, and acoustic measurements.

Logging Unit 1 (0-130 mbsf), which corresponds to lithostratigraphic Units I and II, is characterized by low electrical resistivities and densities.

Logging Unit 2 (130-183 mbsf) is characterized by a small increase in resistivity and density compared to logging Unit 1. The top of Unit 2 corresponds to the bottom of lithostratigraphic Unit II, which was identified as an unconformity separating Pleistocene from upper Miocene sediments.

Logging Unit 3 (183 mbsf-TD) is characterized by an abrupt increase in electrical resistivity, density, and $P$-wave velocity, indicating an increasingly consolidated formation with lower log-derived porosities. Logging Units 2 and 3 correspond to lithostratigraphic Unit III.

Variations in physical properties do not correlate well with the lithostratigraphic and logging units. MAD analyses of porosity and bulk density as well as gamma ray attenuation density data from the multisensor track show anomalously uniform trends throughout most of the section cored from 25 to 180 mbsf. A slightly different trend is observed in the upper 25 mbsf where porosity rapidly decreases to values as low as $55 \%$, coincident with the depth where rapid changes in the core-derived shear strength and electrical resistivity occur. Except for the uppermost 15 mbsf, the magnetic susceptibility record shows extremely low and uniform values of $<50 \times 10^{-7}$ SI. Grain densities generally decrease downhole, crossing all lithostratigraphic boundaries, starting from values of $\sim 2.8 \mathrm{~g} / \mathrm{cm}^{3}$ near the seafloor to $\sim 2.6 \mathrm{~g} / \mathrm{cm}^{3}$ at $175 \mathrm{mbsf}$, but this trend reverses below this depth and again reaches values as high as $\sim 2.8 \mathrm{~g} / \mathrm{cm}^{3}$. This deep increase in grain density and associated increase in bulk density occurs near the top of logging Unit 3, which is characterized by a sudden increase in electrical resistivity and drop in porosity. Analysis of the LWD/MWD density logs from this site yielded 
sediment porosities ranging from $\sim 65 \%$ near the seafloor to $\sim 23 \%$ at 220 mbsf.

IR imaging of the recovered core assisted in immediate gas hydrate detection on the catwalk. At this site, core IR temperatures did not show any significant cold spot anomalies that could be related to gas hydrate dissociation in the recovered core. In situ temperature measurements with the APC3, APCT, and DVTP tools indicate a temperature gradient of $72^{\circ} \pm$ $4^{\circ} \mathrm{C} / \mathrm{km}$ and a seafloor intercept of $3.34^{\circ} \pm 0.34^{\circ} \mathrm{C}$. For measured thermal conductivities of $1.0-1.1 \mathrm{~W} /(\mathrm{m} \cdot \mathrm{K})$, this gradient results in a heat flow of $68-84 \mathrm{~mW} / \mathrm{m}^{2}$. This is consistent with the regional heat flow across the northern Cascadia margin (predicted to be $\sim 72$ $\mathrm{mW} / \mathrm{m}^{2}$ here) but higher than the heat flow measured at Site 889 during Leg 146, indicating that heat flow at this site is not affected by sedimentation and fluid expulsion.

In total, six PCS deployments were made, three in Hole U1329C and three in Hole U1329E. Of the six deployments, four retrieved sediments under pressure. All PCS cores retrieved under pressure were investigated by shipboard degassing experiments. In addition to the PCS, one HRC and one FPC were deployed in Hole U1329E. A full core at near in situ pressure was recovered by the HRC that contained $10 \mathrm{~cm}$ thick high-velocity zones and had a pore space methane concentration of $207 \mathrm{mM}$, equal to $1 \%-2 \%$ gas hydrate in total pore volume or $5 \%-10 \%$ gas hydrate if the gas hydrate were confined to the high-velocity zones. The FPC deployment recovered a core without pressure. Degassing of the four PCS cores from this site that were recovered under pressure showed variable gas concentrations with depth. Cores 311-U1329C-7P (55.6 mbsf) and 311-U1329E7P (73.5 mbsf) from within the predicted depth of the GHSZ had total pore space methane concentrations of 69 and $76 \mathrm{mM}$, respectively, which would equate to a gas hydrate pore volume concentrations of $<0.1 \%$ for both core samples. Core 311-U1329E10P (125.0 mbsf), from near the base of the predicted GHSZ for this site, had a methane concentration of $92 \mathrm{mM}$, which falls below methane saturation at this depth, with no gas hydrate or free gas. The deepest PCS core (311-U1329C-23P; 188.5 mbsf) was taken at a considerable depth below the base of the GHSZ. This deep PCS core had a total pore space methane concentration of $236 \mathrm{mM}$, which suggests a potential pore volume free gas saturation of $2.5 \%$. A potential gas release during the coring operation may have caused this to be an overestimate, yet it still supports the presence of free gas below the BSR at this site.

Interstitial water analyses were carried out on samples from Hole U1329C with additional high-resolu- tion sampling in the uppermost 15 mbsf of Hole U1329E to capture the SMI. Interstitial water salinities decrease from $\sim 34$ to $\sim 30$ at a depth of $\sim 50 \mathrm{mbsf}$ but remain almost constant at values of $\sim 30.5$ until near the bottom of the cored section in Hole U1329D. The deepest water samples from this site (>180 mbsf) show a sharp drop in salinities, from 28 to 22 . A distinct chlorinity minimum $(\sim 15 \mathrm{mM}$ decrease relative to the rest of the trend) is observed at the predicted depth of the BSR. Assuming that this chlorinity minimum is the result of gas hydrate dissociation during core recovery and handling, the observed chlorinity minimum would equate to $\sim 2 \%$ in situ pore space filling of gas hydrate. The strong decrease in chlorinity and salinity below 180 mbsf are coincident with the pronounced increase in electrical resistivity in the LWD/MWD downhole logging data in logging Unit 3 and suggests communication with a deeper-sourced fresher fluid. The $\mathrm{Ca}$ and $\mathrm{Mg}$ depth profiles reflect carbonate and dolomite formation in the shallow section (SMI-60 mbsf) and also suggest mixing with a deeper-sourced fluid over a depth range from $60 \mathrm{mbsf}$ to the BSR.

Organic geochemical studies at Site U1329 included analysis of the composition of volatile hydrocarbons $\left(\mathrm{C}_{1}-\mathrm{C}_{5}\right)$ and nonhydrocarbon (i.e., $\mathrm{O}_{2}$ and $\mathrm{N}_{2}$ ) gases from headspace gas samples, void gas samples, and gas samples recovered during PCS degassing experiments. The predominant hydrocarbon gas found in the cores from Site U1329 was methane; however, we did see an increase in ethane concentrations in the void gases collected from the stratigraphic section overlying the projected depth of the BSR. The increase in ethane concentrations near the BSR is reflected in the plot as low $\mathrm{C}_{1} / \mathrm{C}_{2}$ void gas ratios (Figs. F22, F23). Other studies have shown that preferential selection of ethane into the gas hydrate structure can depress the $\mathrm{C}_{1} / \mathrm{C}_{2}$ ratio of the gas hydrate relative to the source gas. Dissociation of the gas hydrate may, therefore, alter the void gas composition in recovered cores. However, diagenic production of ethane and mixing with a deep thermogenic source can produce the same effect. The $\mathrm{C}_{1} / \mathrm{C}_{2}$ ratios were generally high, suggesting a microbial origin for the observed methane. However, samples collected from deeper than 180 mbsf at this site exhibited significant increases in $\mathrm{C}_{2}-\mathrm{C}_{5}$ concentrations, which suggest an influence from a thermogenic hydrocarbon source. Detailed stable isotope data $\left({ }^{13} \mathrm{C} /{ }^{12} \mathrm{C}\right.$ and $\left.\mathrm{D} / \mathrm{H}\right)$ are required to differentiate the relative contributions of microbial and thermal gases.

Microbiological subsampling was routinely carried out on cores recovered from Hole U1329C. On each core run, PFT was continuously metered into the drilling fluid, and fluorescent microspheres were de- 
ployed on selected cores to investigate potential drilling fluid contamination of the core. These analyses confirmed that the center of each APC core and $\mathrm{XCB}$ biscuit remains undisturbed and suitable for microbiological analyses. Additional IR images were taken on the cut ends of each microbiological core section to document the thermal warming process of the core before subsampling.

When considering the primary research objectives of this site, one of the most important features is its location on the relatively steep slope and the observation that sedimentation at this site is dominated by both slope turbidite deposition and erosional processes. The presence of thick turbidite sequences, including the presence of nonmarine diatoms in the stratigraphic section, is testament to the history of slope-dominated processes. The occurrence of a significant depositional hiatus or erosional event that juxtaposes Miocene with Pleistocene sediments at this site further documents the complex depositional and tectonic histories of this margin. The deepest core and downhole logging penetrations at this site also revealed a complex geologic history with unique high-resistivity, low-porosity conglomerate deposits that may represent thick debris flows.

Geochemical analyses of recovered gas samples and interstitial fluids also document a complex fluid regime for this site. The relatively low interstitial fluid chlorinities observed near the seafloor may reflect paleoceanographic changes in seawater salinity. However, the $\mathrm{Cl}$ concentration decrease with depth strongly suggests communication with a deepseated, fresher fluid, especially below 140 mbsf. For the most part, geochemical analyses of gases from this site reveal a similar story as the analyses of interstitial fluids, with most of the cored section dominated by a simple methane gas-rich system. But near the bottom of the cored section there are indications for the influence of a deeper hydrocarbon source.

Identifying gas hydrate and supportive physical evidence of the BSR at this site remains an elusive goal. As seen in Figures F20 and F21, the subtle BSR is located only $\sim 10 \mathrm{~m}$ above a prominent unconformity, which results in a complicated reflectivity pattern. Precoring LWD/MWD and conventional wireline logging data were used to identify and further characterize potential gas hydrate and related free gas occurrences at each site occupied during this expedition. The presence of gas hydrate is generally characterized by increases in measured electrical resistivities and acoustic velocities. The relative lack of resistivity or acoustic downhole log anomalies at this site supports a general inference of very low to no gas hydrate occurrence at this site. The lack of visual observations of gas hydrate and the occurrence of IR- detected thermal anomalies along the recovered cores also supports the assumption that this site contains little to no gas hydrate. However, geochemical analyses of interstitial fluids from near the depth of the predicted BSR may suggest the presence of a small amount of gas hydrate with minimum dissolved chloride concentration at $\sim 125$ mbsf, coincident with the predicted BSR depth. The HRC core taken from $114.6 \mathrm{mbsf}$ had high-velocity layers that contained $5 \%-10 \%$ gas hydrate. The relative increase in ethane concentrations immediately above the depth of the BSR may indicate the presence of gas hydrate. Degassing experiments of three PCS cores that were collected from within the zone of predicted gas hydrate stability contained little gas hydrate, if any. However, a PCS core from $188.5 \mathrm{mbsf}$ in Hole U1329C does suggest the occurrence of a free gas phase. The presence of free gas below 160 mbsf may also be supported by a distinct change in seismic reflection character in the low-frequency seismic data of Line 89-08 (Figs. F21, F23). In contrast to the shallower section of the seismic line above $1.5 \mathrm{~s}$ twoway traveltime (TWT), no clear reflection can be identified and seismic frequency is strongly reduced below.

This site was intended to characterize the eastern limit of gas hydrate occurrence on the northern Cascadia margin and establish an understanding of the geologic controls on the occurrence of gas hydrate along the transect of sites established during this expedition. All of the objectives set for Site U1329 are fulfilled.

\section{Summary and implications}

The specific objectives of this expedition were to test gas hydrate formation models and constrain model parameters, especially those that account for the formation of concentrated gas hydrate occurrences through upward transport of methane-bearing fluids. During Expedition 311 a series of research sites across a transect through the northern Cascadia margin was established by drilling and coring four sites that extend from the westernmost accreted ridge (Site U1326, representing the youngest gas hydrate formation) and the first slope basin (Site U1325) to the second accreted ridge midslope (Site U1327) and a site at the eastern boundary of the inferred gas hydrate occurrence along this margin (Site U1329). We also cored and logged a cold vent (Site U1328), which represents a site of focused fluid and gas flow.

We collected the necessary data for characterizing gas hydrate proxies such as interstitial water chlorinities, core-derived gas chemistry, core physical property, IR images of the recovered core, and downhole 
measured logging data. Geophysical characterization of each site was accomplished by the LWD/MWD program, conventional wireline deployments, and two VSP experiments. Extensive evidence for the presence of gas hydrate at all sites, except Site U1329, was collected from electrical resistivity and $P$ wave velocity logs, IR imaging, and interstitial water and gas sampling, as well as from direct sampling of visible gas hydrate (Figs. F24, F25).

The main objectives of this cruise are considered fulfilled with only few elements having only partial success rates, such as temperature tool deployments and pressure coring, which are mainly a result of poor weather conditions.

\section{Occurrence of gas hydrate}

\section{Bottom-simulating reflectors}

The occurrence of gas hydrate has historically been inferred from the presence of a BSR in seismic images (Shipley et al., 1979). BSRs as ascribed to gas hydrate were first mentioned in the literature in 1977 from the Blake Ridge (e.g., Tucholke et al., 1977) and have since been a tool for gas hydrate detection. The BSR is the result of an impedance contrast generated by the transition from gas hydrate-bearing sediments above to gas hydrate-free and potentially free gasbearing sediments underneath the interface. The presence of gas hydrate in sediments increases seismic $P$-wave velocity, whereas the presence of free gas (even small amounts) drastically reduces seismic $P$ wave velocity. The density is not expected to change much across this interface because the density changes introduced by the presence of small amounts of gas hydrate and free gas are relatively small. The BSR reflection shows a phase-reversed polarity relative to that of the seafloor due to the negative impedance contrast at the interface.

The BSR has also been described as a frequencydependent reflection (Chapman et al., 2002), which results from a finite-thickness gradient zone, in which velocity decreases from the elevated values above to low values below the interface. In conventional seismic surveys with low frequencies, the BSR appears as a strong reflection (see, e.g., Fig. F3), but with increasing frequency the magnitude of this reflection decreases.

BSRs have been widely observed in seismic data collected across the northern Cascadia margin (Hyndman and Spence, 1992; Hyndman, 1995) and were used to map the general distribution of gas hydrate along this margin (Fig. F1). At all sites visited during Expedition 311, BSRs were previously imaged with various seismic surveying techniques ranging over frequencies from 20 to $650 \mathrm{~Hz}$ (for a summary, see
Hyndman et al., 2001). The depth to the BSR is a critical element in gas hydrate research because it is usually a measure of the base of the GHSZ. However, it has also been shown that the BSR can occur away from the actual base of the stability zone at shallower or even deeper depths (Xu and Ruppell, 1999), where it depicts the first occurrence of free gas in the subsurface. Gas hydrate can also occur below the BSR, or even at a second BSR, in the form of Structure II gas hydrate.

The depth to the BSR in TWT has been determined from several crossing sections at each site visited during the expedition, and the average traveltime was then converted to depth using velocities defined at Sites 889/890 from a VSP (Mackay et al., 1994). The BSR at Site 889 occurs at a depth of $\sim 275$ ms TWT, equivalent to a depth of 225 mbsf with the average velocity of $1636 \mathrm{~m} / \mathrm{s}$ for the sediment column from seafloor to the BSR. This velocity was used across the entire margin for all sites visited and thus introduces a significant uncertainty in the depth assignment of the BSR. We therefore defined two extreme velocity profiles that describe sediments without gas hydrate (average velocity $=1619 \mathrm{~m} / \mathrm{s}$ ) and with concentrations well above what was observed (and inferred) at Site 889 (average velocity $=1653 \mathrm{~m} / \mathrm{s}$ ). The velocity increase appears very small; however, this is the result of only a thin sediment column over which the presence of gas hydrate was inferred (i.e., only $100 \mathrm{~m}$ above the BSR), leaving $125 \mathrm{~m}$ of sediment above this non-gas hydrate-bearing column. The range in velocity results then in a shift in the BSR depth by about $\pm 2.5 \mathrm{~m}$.

Throughout Expedition 311, special effort was made to better define the depth of the base of gas hydrate stability. Among the proxies used to define this boundary and to compare it to the predicted BSR depth are

- Downhole temperature measurements,

- Well-log measurements of $P$-wave velocity and electrical resistivity,

- Pore water chlorinity,

- IR imaging,

- $\mathrm{C}_{1} / \mathrm{C}_{2}$ ratios of the void gas combined with the occurrence of propane and butanes, and

- Visual core descriptions and notes on gas hydraterelated sediment textures.

There are notable differences between the individual techniques, as they are highly dependent on how the measurements are conducted and the resolution or sensitivity of a particular measurement and as they are biased by core recovery (IR, pore water chemistry, and gas chemistry) and sampling density 
(e.g., frequency of temperature tool deployments and linear regression analysis).

\section{Gas hydrate stability calculations}

Expedition 311 featured 36 temperature tool deployments in an attempt to characterize the thermal regime of sites drilled along the Expedition 311 transect (Table T2). Three standard IODP temperature tools were deployed during the expedition, including the APCT (11 times), DVTP (11 times), and DVTPP (5 times). We also deployed the new APC3 tool nine times. Figure F26 shows a compilation of all in situ temperature estimates from Expedition 311 compared to results from Site 889. The implied heat flow, assuming a constant thermal conductivity of $1.1 \mathrm{~W} /(\mathrm{m} \cdot \mathrm{K})$, is also shown (see Fig. F38 in the "Site U1326" chapter) and compared to the regional heat flow determined by Hyndman and Wang (1993). Heat flow across the lower slope (Sites U1325, U1327, and U1328) appears to be depressed compared to the regional heat flow pattern, which is consistent with perturbation by a high sedimentation rate and upward fluid advection (Hyndman and Davis, 1992). Postcruise analysis will focus on detailed examination of data uncertainties and on processes to explain inter- and intrasite variation.

The primary goal of the temperature tool deployment program during Expedition 311 was to obtain the data needed to calculate the depth to the base of the GHSZ at each of the sites. Gas hydrate exists under a limited range of temperature and pressure conditions such that the depth and thickness of the zone of the GHSZ can be calculated. Most gas hydrate stability studies assume that the pore pressure gradient is hydrostatic $(9.795 \mathrm{kPa} / \mathrm{m})$. However, the seafloor temperature and geothermal gradient for any given site can be highly variable. The temperature data acquired during this expedition have been used to make a preliminary estimate of the depth to the base of the GHSZ at each site. Pure methane gas hydrate was assumed and interstitial water salinities from the onboard analysis of core samples were used to estimate the depth to the base of the GHSZ at each site. The results of these preliminary calculations have been reported as a range of depths:

- Site U1325 = 250-300 mbsf (predicted depth = 230 mbsf).

- Site U1326 = 250-270 mbsf (predicted depth $=234$ mbsf).

- Site U1327 = 225-250 mbsf (predicted depth $=223$ mbsf).

- Site U1328 = 220-245 mbsf (predicted depth = 219 mbsf).
- Site U1329 = 127-129 mbsf (predicted depth = 126 mbsf).

For the most part, the calculated depth to the base of the GHSZ for each site falls near the estimated depth of the BSR as inferred from seismic data. In the case of Sites U1325 and U1326, however, it appears that the estimated depth of the BSR is less than what would be expected from the gas hydrate stability calculations. It should also be noted that the linear regression used to estimate the subsurface temperatures in the above calculations may not be appropriate for environments that are affected by fluid advection (e.g., the cold vent Site U1328). A more detailed temperature measuring program is required to better resolve the base of the GHSZ and will be addressed in future drilling under this project by deployments of distributed fiber-optic temperature cables that allow continuous recording of the temperature field on a vertical sampling density of $<1 \mathrm{~m}$.

\section{Core analysis}

\section{Visual descriptions}

Gas hydrate occurrence can be documented by a variety of methods. The most obvious and fundamental method is by direct visual observation of cores. During Expedition 311, numerous visual observations of gas hydrate were made at the cold vent location, Site U1328, where a thick section of highly concentrated gas hydrate-bearing strata in the upper 35 mbsf was inferred from LWD/MWD and precruise studies. From cores in this interval, numerous gas hydrate pieces were recovered, some measuring as much as $5-8 \mathrm{~cm}$ in diameter (Fig. F25). Gas hydrate was also observed at other sites, more typically seen as small nodules or filling pores within sandy layers (Fig. F24). A list of all gas hydrate samples retrieved for postcruise analysis is given in Table T4.

Because gas hydrate, especially disseminated gas hydrate, begins to dissociate and may completely decompose during core recovery, direct visual observation may not be possible. Thus, indirect or proxy methods related to the physical and chemical consequences of dissociation must be used to document gas hydrate occurrences.

Gas hydrate dissociation releases gas and water, which should physically disturb the original sedimentary fabric. Previous observations have indicated two textures that result from gas hydrate dissociation (Westbrook, Carson, Musgrave, et al., 1994; Kastner et al., 1995; Lorensen et al., 2000, Tréhu, Bohrmann, Rack, Torres, et al., 2003). Soupy texture describes intervals that are water saturated and have lost all primary sedimentary structure, which are thought to 
represent areas that once contained larger pieces or veins of gas hydrate. Intervals with many small, round voids are termed mousselike and are interpreted to represent dissociation of disseminated gas hydrate. During Expedition 311, soupy and mousselike textures were common and associated with intervals where direct and other indirect evidence of gas hydrate were noted. Site U1329 was the only site where these textures were not observed. At the cold vent Site U1328, soupy texture was common in the upper shallow gas hydrate zone (lithostratigraphic Unit I), whereas mousselike textures were observed throughout the deeper gas hydrate zone. Sites U1327, U1326, and U1325 also displayed soupy and mousselike textures. At Site U1326, the lower part of a section with a notable IR anomaly (Section 311U1326-18X-4) was sectioned and opened immediately. The sediment in this core had a very unusual texture, remaining cohesive and "foamy" rather than soupy or mousselike. Sediment in this section lost its foamy texture in less than an hour, collapsing to a stiff, dry sediment that occupied an estimated $25 \%$ of the original volume in the core liner.

\section{Interstitial water chemistry and infrared imaging}

The presence of gas hydrate in situ has often been inferred by freshening of pore water chlorinity or salinity relative to a defined baseline (e.g., Kastner et al., 1995). When gas hydrate forms in the subsurface, the process initially increases pore water chlorinity and salinity because gas hydrate formation excludes salt. Over geologic time, the excess salt is removed by advective and diffusive processes and the background pore water chemistry is reestablished. In case of rapid and relatively recent gas hydrate formation, this process is incomplete and high-pore water chlorinity and salinity brines are observed (e.g., Site 1249 of southern Hydrate Ridge during ODP Leg 204; Tréhu, Bohrmann, Torres, Rack, et al., 2003). Such a system was also cored at the cold vent Site U1328 during this expedition.

When a gas hydrate-bearing core is retrieved, gas hydrate dissociates as the core is raised and processed, leaving freshwater behind, which can be detected by interstitial water analyses. A summary of all interstitial water chlorinity profiles linked to LWD/MWD RAB-derived borehole images is shown in Figure F27. The definition of an interstitial water chlorinity baseline has proven difficult because the effect of pore water freshening from gas hydrate dissociation and advection of fresher pore fluids from greater depth cannot easily be distinguished with chlorinity and salinity measurements alone. Additional shore- based pore water analyses, such as measurements of $\mathrm{Sr}, \mathrm{B}$, or I isotopes, are required to distinguish these processes (Kastner et al., 1995; Teichert et al., 2005; Fehn et al., 2006).

The catwalk procedure for collecting interstitial water samples during this expedition had been adapted from previous "gas hydrate" expeditions and was linked to IR imaging. The presence of gas hydrate in the core can be detected (if not visually) by a decrease in core temperature caused by the cooling from gas hydrate dissociation. One of the early systematic approaches to core temperature measurements was during Leg 164 using an array of digitally recorded thermocouple probes (Paull, Matsumoto, Wallace, et al., 1996). Initial development of the IR imaging technique was accomplished during Leg 201, where thermal anomalies in IR images were associated with gas hydrate and voids (Ford et al., 2003). Systematic IR thermal imaging of the surface of the core liner was first fully implemented during Leg 204 (Tréhu, Bohrmann, Torres, Rack, et al., 2003). During Expedition 311, an improved version of the IR system was used to systematically scan the core for IR cold spot anomalies. A summary of all IR profiles from continuous coring are compared to Archie-derived pore water saturations $\left(S_{\mathrm{w}}\right)$ and LWD/ MWD RAB-derived borehole images, shown in Figure F28.

Generally, several interstitial water samples were collected from most cores that did not show IR coldspot anomalies to define the in situ background pore water chemistry. In addition, we directly sampled IRimaged cold spots in cores to measure the amount of pore water freshening associated with gas hydraterelated IR temperature anomalies. This will help to further calibrate the IR measurements and delineate anomalous trends from the background pore water chemistry. Experiments during Leg 204 showed that cold spot-related interstitial water freshening is focused spatially to a range of a few centimeters around the IR anomaly (Tréhu et al., 2004a, 2004b). Each IR cold spot sampled was therefore carefully analyzed during this expedition. Once in the chemistry laboratory, the handheld IR camera was used to isolate the cold anomaly so a subsample of the sediment that had contained gas hydrate could be separated from background sediment. The cold material was squeezed separately from the background material. Gas hydrate inferred from pore water freshening and IR anomalies preferentially occurs in the coarsergrained material. However, in a few cases, freshening was also observed in the clays, although to a lesser extent relative to the adjacent sands. 


\section{Gas chemistry}

Organic geochemical studies focused on volatile hydrocarbon gases from headspace samples, void gases, and selected gas hydrate samples. At all sites, analyses showed that methane is the dominant hydrocarbon gas. However, the presence and distribution of higher hydrocarbons $\left(\mathrm{C}_{2+}\right)$ provided useful information about the occurrence and possibly the type of gas hydrate. In particular, studies have shown that gas hydrate forms with the preferential selection of ethane into the gas hydrate structure, which is released during dissociation. At most sites where other visual or proxy data indicated the presence of gas hydrate, void gas and selected gas hydrate and PCS samples contained elevated ethane concentrations and depressed $\mathrm{C}_{1} / \mathrm{C}_{2}$ ratios (Fig. F29). In some gas hydrate-bearing intervals, elevated propane and isobutane concentrations were observed, which suggest there may also be Structure II gas hydrate present.

\section{Downhole logging analysis}

Gas hydrate is characterized by unique chemical compositions and distinct electrical resistivity and acoustic physical properties. It is therefore possible to identify and further characterize gas hydrate-bearing sediment properties (e.g., porosities and gas hydrate saturations) with downhole logging tools. In the case of Expedition 311, the standard downhole wireline logging program was augmented with a precoring LWD/MWD dedicated drilling-logging program. The downhole LWD/MWD logging data acquired during the start of this expedition were used to direct the special pressure coring program and make decisions on other critical special tool deployments. The LWD/MWD data, along with downhole wireline logging data, were also used to identify and quantify the occurrence of gas hydrate at each site drilled along the Expedition 311 transect.

As shown in Figure F30, the LWD/MWD-derived $\mathrm{RAB}$ images of borehole resistivities reveal numerous apparent high-resistivity intervals (shown as light color bands) within the stratigraphic section above the projected depth of the BSR. Also shown in Figure F30 are the Archie-derived gas hydrate saturations for each of the LWD/MWD-logged holes. Except for the cold vent Site U1328, the downhole logging-inferred gas hydrate occurrences appear to be first observed at a minimum depth of 70-100 mbsf; and in most cases we see evidence for gas hydrate near the base of the predicted GHSZ. The apparent low water saturations below the BSR likely depict the occurrence of free gas. The downhole logging data from Site U1329 revealed relatively little evidence of gas hydrate. The downhole logging data from Sites U1327 and U1326, however, are dominated by the appearance of thick high-resistivity intervals near 100 mbsf at each site. In the case of Site U1327, we see an $18 \mathrm{~m}$ thick (120-138 mbsf) high-resistivity interval with peak LWD/MWD resistivity values exceeding $12 \Omega \mathrm{m}$, whereas in Hole U1326A we see a 35 $\mathrm{m}$ thick interbedded section (72-138 mbsf) of gas hydrate-bearing sands and non-gas hydrate-bearing clay sections. The logging-measured resistivities in gas hydrate-bearing sands at Site U1326 exceed 40 $\Omega \mathrm{m}$ for part of the section. Archie analyses of these high-resistivity intervals at both sites indicate gas hydrate saturations possibly exceeding $50 \%$ of pore volume. The gas hydrate occurrence at Site U1325, however, appears to be distributed throughout the cored section of the site with the gas hydrate concentrated in thinly bedded sand units measuring between 5 and $20 \mathrm{~cm}$ thick. The downhole LWD/MWD logging data from Site U1328 reveal a very distinct zone of high resistivity extending from the seafloor to $\sim 50$ mbsf. Archie analysis of the resistivity logging data from Site U1328 indicates this near-surface high-resistivity interval may contain a significant amount of gas hydrate. Closer examination of the RAB images from the cold vent Site U1328 also reveals numerous high-angle fractures cutting through the shallow gas hydrate-bearing section, which may serve as migration conduits for gas from potentially deeper sources.

\section{Pressure core analysis}

Expedition 311 attempted the most ambitious pressure coring and onboard pressure core analysis program in the history of ocean drilling. Pressure cores retrieved at in situ pressure were used to determine gas hydrate quantity using degassing techniques and mass balance calculations. Pressure cores were also used to investigate gas hydrate distribution using nondestructive measurement of the physical properties of the cores at in situ pressures. Large improvements in temperature control over previous expeditions (e.g., Leg 204; Tréhu, Bohrmann, Torres, Rack, et al., 2003) made the recovery and analysis of pressure cores more practical. Pressure coring is crucial for understanding the concentration of gas hydrate and free methane gas in marine sediments, their nature and distribution, and their effect on the intrinsic properties of the sediment.

Pressure cores were collected using the IODP PCS and HYACINTH FPC and HRC pressure corers. The PCS is a downhole tool designed to recover a $1 \mathrm{~m}$ long sediment core with a diameter of $4.32 \mathrm{~cm}$ at in situ pressure up to a maximum of $69 \mathrm{MPa}$ (Pettigrew, 1992; Graber et al., 2002). The European Union- 
funded HYACE/HYACINTH programs developed two wireline pressure coring tools: a percussion corer (FPC) and a rotary corer (HRC), which were designed to cut and recover core in a wide range of lithologies.

During Expedition 311, the PCS retrieved pressurized sediments for onboard degassing experiments. Controlled release of pressure from the PCS through a manifold permits

- Collecting all gas discharged from the sediment's free gas and gas hydrate phase for quantitative and qualitative analyses,

- Estimating the in situ abundance of gas hydrate and free gas based on mass balance, methane solubility, and gas hydrate stability considerations (Dickens et al., 1997),

- Identifying the presence of gas hydrate from volume-pressure-time relations (Hunt, 1979; Dickens et al., 2000; Milkov et al., 2004), and

- Monitoring the controlled decomposition of gas hydrate with nondestructive methods in the course of the degassing experiment.

Of 24 PCS runs carried out during Expedition 311, 16 returned sediment under pressure. Each PCS core was X-rayed before and after degassing for core characterization and to guide subsampling for interstitial water and gas headspace. Gas hydrate and free gas concentration estimates were determined from the mass balance calculations and are superimposed on the Archie-derived water saturation logs in Figure F30. The PCS-derived pore water gas hydrate and free gas concentrations agree with estimates from LWD/ MWD data. The results of the 16 successful PCS measurements are displayed in Figure F31, showing the calculated methane concentrations as function of depth and their position relative to the gas hydrate phase and methane solubility boundaries defined from the $\mathrm{Xu}$ model $(\mathrm{Xu}, 2002,2004)$. The largest amount of gas hydrate within a PCS core was $40 \%$ of the pore space as inferred from degassing of Core 311-U1326C-12P, recovered from a depth of 83.7 mbsf within a high-electrical resistivity zone (Fig. F30). Other significantly large amounts of gas hydrate were inferred from Cores 311-U1328B-4P (15\%) and 311-U1328E-10P (38\%) at the cold vent (Table T3). A very large amount of free gas was inferred from the degassing of Core 311-U1328E-13P $(58 \%)$ recovered from 233 mbsf near the base of the GHSZ. However, the core did not show typical degassing features after the experiment, such as gas expansion cracks or large voids combined with mousselike or soupy texture. It was concluded that the free gas was accidentally trapped within the outer chamber of the PCS and as it flowed into the borehole from a free gas-bearing formation.

In total, three HRC cores and one FPC core were stored under in situ pressures for future shore-based analyses. Onboard Expedition 311, these cores were $\mathrm{X}$-rayed and analyzed with the multisensor core logger to measure density and $P$-wave velocity. Immediate postcruise analysis showed that wispy, low-density X-ray textures in Core 311-U1327D-14E were gas hydrate veins and that anomalous high-velocity zones in Core $311-\mathrm{U} 1329-9 \mathrm{E}$ contained $5 \%-10 \%$ gas hydrate by pore volume.

\section{Remote sensing calibration}

The presence of gas hydrate in marine sediments is mainly inferred from the presence of BSRs on seismic sections. Quantification of gas hydrate concentrations from remote sensing techniques such as seismic or CSEM methods has been attempted at this margin (e.g., Yuan et al., 1996, 1999; Yuan and Edwards, 2000; Hyndman and Spence, 1992), but these efforts need further calibration from borehole data, especially $P$-wave velocity, density, porosity, and electrical resistivity. Although borehole data may provide the needed calibration data, strong lateral heterogeneity in the derived gas hydrate concentrations and physical properties between adjacent holes only several tens of meters apart was observed at multiple sites visited during this expedition. Structural control of the gas hydrate occurrence, local dip of the formation, and other tectonic complications make estimates of gas hydrate concentration from remote-sensing techniques a challenging task and will be addressed postcruise in various studies.

\section{Gas hydrate geologic system}

In recent years significant progress has been made in addressing key issues on the formation, occurrence, and stability of gas hydrate in nature. The concept of a "gas hydrate geologic system" approach is gaining some acceptance. In this approach, the individual factors that contribute to the formation of gas hydrate occurrences, such as gas source, gas and water migration, emplacement, and growth of the gas hydrate in a suitable host sediment, are identified and quantified.

The availability of large quantities of hydrocarbon gas from either microbial or thermogenic sources or both is an important factor controlling the formation and distribution of natural gas hydrate (Kvenvolden, 1988). Stable carbon isotope analyses indicate that the methane in most oceanic gas hydrate is derived from microbial sources. However, molecular 
and isotopic analyses indicate a thermal origin for portions of the gas in several of the gas hydrate occurrences on the Cascadia margin (Pohlman et al., 2005). Geologic controls on fluid migration control the availability of gas. If migration pathways are not available, it is unlikely that a significant volume of gas hydrate would accumulate. Therefore, geologic parameters such as water and gas chemistry, as well as sediment permeability and the nature of faulting, must be evaluated to determine if the required gas and water can be delivered to the sedimentary section potentially hosting the gas hydrate.

Analysis of interstitial waters during Expedition 311 gave us important insight to fluid and gas sources and their migration within the northern Cascadia margin. At Sites U1327 and U1329 we see general decreases in salinity and chlorinity with depth, suggesting dilution. It was concluded that the dilution profile observed is primarily dominated by diffusive communication with an advective low-chlorinity fluid system at greater depth, not gas hydrate dissociation. In addition to chlorinity, concentrations of $\mathrm{Na}, \mathrm{K}, \mathrm{Ca}$, and $\mathrm{Mg}$ also decrease with depth, supporting the suggestion of communication with a deepersourced fresher fluid. At the vent Site U1328, salinities and chloride concentrations remain almost constant below the highly concentrated surface section of gas hydrate, again suggesting communication with a fluid at greater depth. But in this case, the waters have undergone less freshening than at Site U1327. The salinity and chlorinity profiles at Sites U1326 and U1325, however, trend toward concentrations higher than seawater, which was interpreted to indicate low-temperature diagenetic reaction. A plausible candidate for such a reaction is alteration of volcanic ash to clay minerals and/or zeolites. These reactions consume water and, hence, increase in situ chlorinity values. Analysis of core-derived hydrocarbon gases along the Expedition 311 transect, when linked to interstitial water chemistries, also shows communication with a deeper source.

Hydrocarbon headspace gas measurements show that methane is the dominant hydrocarbon gas at every site along the transect. Although ethane and more complex hydrocarbon gas concentrations were low, the occurrence of more complex hydrocarbon gases generally indicates contribution of a deeper gas source, in agreement with the interstitial water chemistry results. It was also shown that the methane needed to sustain the shallow gas hydrate formation at the Site U1328 vent site was likely supplied along faults or fracture zones from a deeper source. It is also notable that the concentration of ethane and other gas hydrate-forming gases, including propane and isobutane, increase within the gas samples col- lected from the cores crossing the predicted BSR depth at several sites. This gas geochemistry also suggests the presence of a mixture of Structure I and Structure II gas hydrate.

By integrating the results of the interstitial water and gas geochemistry studies, we have shown that the occurrence of gas hydrate along the Expedition 311 transect is controlled, in part, by the upward advection and diffusion of methane and other gas hydrate-forming gases from a deeper source. In the case of vent Site U1328, we see the influence of a focused flow system that has contributed to the development of a localized concentrated gas hydrate accumulation.

For the most part, the interpretation of downhole logging data and linked IR imaging and interstitial water analyses from the sites drilled along the Expedition 311 transect indicate that the occurrence of concentrated gas hydrate is mostly controlled by the presence of sand-rich sediments. The occurrence of the relatively thick, highly concentrated gas hydrate accumulations within 100 mbsf at Sites U1326 and U1327 are also partially controlled by the presence of suitable host sands; but we may also be seeing the effect of regional gas solubility in water on the occurrence of gas hydrate. We see relatively little evidence of gas hydrate or gas above these depths at any other site visited during Expedition 311, other than the Site U1328 vent site at which free gas has been observed venting from the seafloor.

Preexpedition models that had predicted the occurrence of a highly concentrated gas hydrate section (50-100 m thick) just above the base of the GHSZ do not take into account the geologic complexity revealed during Expedition 311. Specifically, the occurrence of gas hydrate appears to include a contribution from mixed microbial and thermogenic gas sources. The occurrence of migration conduits and host sands also controls the spatial distribution of gas hydrate on the Cascadia margin.

\section{Preliminary scientific assessment}

The revised IODP U.S. Implementing Organization (USIO) riserless vessel Phase 1 schedule included an additional 15 operational days for Expedition 311. The revised schedule included a port call in Astoria, Oregon, at the start and in Victoria, British Columbia, at the end of Expedition 311, with 37 total operational days on site. The original operations plan for Expedition 311 was based on 22 days at five sites.

The main change to accommodate the additional 15 days was in expanding the operations plan to a three-hole approach at each site. Hole A was dedi- 
cated to LWD and MWD operations. Hole B was a continuous coring hole for APC/XCB coring, with additional temperature measurements using the APCT/APC3/DVTP/DVTPP tools as well as monitoring of pressure/temperature conditions by deploying the advanced piston corer methane (APCM) tool. We also planned to deploy the PCS at three intervals in Hole B. These three PCS cores were to be used for degassing experiments only. Because core recovery in gas hydrate-bearing sediments is challenging, we took advantage of the third hole to spot-core in missed intervals from Hole B. Hole $\mathrm{C}$ was mainly dedicated to pressure coring, with a total of six deployments alternating the PCS, HPC, and FPC systems. Hole $\mathrm{C}$ was wireline logged after coring operations were completed. The additional time and associated flexibility in the program allowed us to accommodate weather problems and operational complexities.

For this expedition, we carried out LWD/MWD operations prior to coring each site. The LWD/MWD logging program surpassed all expectations. The newly developed LWD/MWD safety protocol provided an effective means to deal with concerns associated with shallow gas hazards. The logging data guided special tool deployments (PCS, FPC, and HRC) in addition to providing high-quality downhole measurements, which were used to identify and characterize gas hydrate occurrences.

Uncertainty in the detailed velocity profile at each site complicates our effort to resolve critical issues related to the depth of the BSR. Additional VSPs and walkaway VSPs will be needed to address these issues.

Weather conditions impacted operations throughout the expedition. A combination of adverse weather and severe sea state resulted in $>4$ days of schedule delays. In addition, the ship heave conditions reduced core recovery and quality. Temperature tool and pressure core deployments were also affected by adverse weather conditions.

Many of the gas hydrate accumulations encountered during the expedition occurred in sand-rich sediment sections. This condition negatively affected recovery with standard XCB and specialized pressure core systems.

IODP and Transocean staff members are complimented for their ability to execute complex operations and demonstrated outstanding flexibility in adapting to changing requirements.

The original proposal 553-Full2 Cascadia margin gas hydrate included deployment of long-term monitoring devices such as ACORK instruments and fiberoptic distributed temperature sensing (DTS) cables as well as coring and logging of a reference site (proposed Site CAS-04B) in the deep Cascadia Basin west of the deformation front to characterize the incoming, undeformed, gas hydrate-free sediment column. The long-term monitoring aspect of the proposal is closely linked to the NEPTUNE cable observatory and is planned to connect the ACORK and DTS instruments by a node near Site 889 . The NEPTUNE program is laying a cable during the next $2 \mathrm{y}$ that follows the transect established during this expedition.

Although Expedition 311 addressed many key issues of gas hydrate occurrence on this margin, several important questions remain unanswered and need to be addressed during future drilling. One of the most important aspects in gas hydrate research is establishing the extent of the GHSZ. Capturing the temperature field with coarsely spaced single-point measurements and regression analyses to establish linear temperature gradients was shown to be challenging because of weather conditions and inappropriate in a region dominated by advective fluid/gas flow. It is, therefore, crucial to deploy a system like DTS that allows measurements on a higher vertical resolution to map the GHSZ in more detail, especially around the base of the stability zone. This system will provide the answers to critical questions (e.g., of the potential occurrence of Structure II gas hydrate and temporal changes in the system).

Expedition 311 provided evidence for strong lateral heterogeneity between adjacent bore holes, especially within sites where the gas hydrate occurs mainly within the accreted sediment complex (e.g., Site U1327). The occurrence of gas hydrate appeared to be driven by local variation of methane solubility as well as proximity of suitable host sediments (coarser-grained turbidite sands). A key question is how sediment permeability controls fluid and gas migration. Permeability may be on a sediment grain scale, a centimeter scale (the scaly fabric observed in previous ODP clastic accretionary prism cores), or on a fault/fracture level scale. A key experiment to measure permeability on these scales is given by the proposed dual ACORK deployment. Two boreholes spaced several tens of meters apart equipped with the ACORK instruments are required to carry out a cross-hole hydrogeologic fluid-flow experiment. The two boreholes additionally offer the opportunity to deploy sensors for geophysical measurements (e.g., multicomponent geophones for active and passive seismic experiments, resistivity receivers for CSEM experiments, and strainmeters to measure long-term deformation [to be linked with the newly installed strainmeters at the Pacific Geoscience Centre in Sidney and other sites along the margin and as part of the proposed NEPTUNE cable observatory]). 


\section{References}

Aldred, W., Cook, J., Carpenter, B., Hutchinson, M., Lovell, J., Rezmer-Cooper, I., and Leder, P.C., 1998. Using downhole annular pressure measurements to improve drilling performance. Oilfield Rev., Winter:40-55.

Chapman, N.R., Gettrust, J., Walia, R., Hannay, D., Spence, G.D., Wood, W., and Hyndman, R.D., 2002. High-resolution, deep-towed, multichannel seismic survey of deep-sea gas hydrates off western Canada. Geophysics, 67(4):1038-1047. doi:10.1190/1.1500364

Collett, T.S., 2000. Quantitative well-log analysis of in-situ natural gas hydrates [Ph.D. dissert.]. Colorado School of Mines, Golden.

Collett, T.S., Riedel, M., Malone, M.J., and the Expedition 311 Project Team, 2005. Cascadia margin hydrates. IODP Sci. Prosp., 311. doi:10.2204/iodp.sp.311.2005

Dallimore, S.R., and Collett, T.S. (Eds.), 2005. Scientific Results from the Mallik 2002 Gas Hydrate Production Research Well Program, Mackenzie Delta, Northwest Territories, Canada. Bull.-Geol. Surv. Canada, 585.

Dallimore, S.R., Collett, T.S., and Uchida, T., 1999. Overview of science program, JAPEX/JNOC/GSC Mallik 2L38 gas hydrate research well. In Dallimore, S.R., Uchida., T., and Collett, T.S. (Eds.), Scientific Results from JAPEX/ JNOC/GSC Mallik 2L-38 Gas Hydrate Research Well, MacKenzie Delta, Northwest Territories Canada. Bull.-Geol. Surv. Canada.

Davis, E.E., and Hyndman, R.D., 1989. Accretion and recent deformation of sediments along the northern Cascadia subduction zone. Geol. Soc. Am. Bull., 101(11):1465-1480. doi:10.1130/00167606(1989)101<1465:AARDOS>2.3.CO;2

Dickens, G.R., Paull, C.K., Wallace, P., and the ODP Leg 164 Scientific Party, 1997. Direct measurement of in situ methane quantities in a large gas-hydrate reservoir. Nature (London, U. K.), 385:427-428. doi:10.1038/ $385426 \mathrm{a} 0$

Dickens, G.R., Wallace, P.J., Paull, C.K., and Borowski, W.S., 2000. Detection of methane gas hydrate in the pressure core sampler (PCS): volume-pressure-time relations during controlled degassing experiments. In Paull, C.K., Matsumoto, R., Wallace, P.J., and Dillon, W.P. (Eds.), Proc. ODP, Sci. Results, 164: College Station, TX (Ocean Drilling Program), 113-126. [HTML]

Fehn, U., Lu, Z., and Tomaru, H., 2006. Data report: ${ }^{129} \mathrm{I} / \mathrm{I}$ ratios and halogen concentrations in pore water of the Hydrate Ridge and their relevance for the origin of gas hydrates: a progress report. In Tréhu, A.M., Bohrmann, G., Torres, M.E., and Colwell, F.S. (Eds.), Proc. ODP, Sci. Results, 204 [Online]. Available from World Wide Web: http://www-odp.tamu.edu/publications/204_SR/ 107/107.htm.

Ford, K.H., Naehr, T.H., Skilbeck, C.G., and the Leg 201 Scientific Party, 2003. The use of infrared thermal imaging to identify gas hydrate in sediment cores. In D'Hondt, S.L., Jørgensen, B.B., Miller, D.J., et al., Proc. ODP, Init. Repts., 201, 1-20 [CD-ROM]. Available from: Ocean Drilling Program, Texas A\&M University, College Station TX 77845-9547, USA. [HTML]
Graber, K.K., Pollard, E., Jonasson, B., and Schulte, E. (Eds.), 2002. Overview of Ocean Drilling Program Engineering Tools and Hardware. ODP Tech. Note, 31 [Online]. Available from World Wide Web: <http:// www-odp.tamu.edu/publications/tnotes/tn31/ INDEX.HTM>.

Hunt, J.M., 1979. Petroleum Geochemistry and Geology: San Francisco (W.H. Freeman).

Hyndman, R.D., 1995. The lithoprobe corridor across the Vancouver Island continental margin: the structural and tectonic consequences of subduction. Can. J. Earth Sci., 32:1777-1802.

Hyndman, R.D., and Davis, E.E., 1992. A mechanism for the formation of methane hydrate and seafloor bottomsimulating reflectors by vertical fluid expulsion. J. Geophys. Res., 97:7025-7041.

Hyndman, R.D., Moore, G.F., and Moran, K., 1993. Velocity, porosity, and pore-fluid loss from the Nankai subduction zone accretionary prism. In Hill, I.A., Taira, A., Firth, J.V., et al., Proc. ODP, Sci. Results, 131: College Station, TX (Ocean Drilling Program), 211-220.

Hyndman, R.D., Moran, K., and Yuan, T., 1999. The concentration of deep sea gas hydrates from downhole resistivity logs and laboratory data. Earth Planet. Sci. Lett., 172(1-2):167-177. doi:10.1016/S0012821X(99)00192-2

Hyndman, R.D., and Spence, G.D., 1992. A seismic study of methane hydrate marine bottom simulating reflectors. J. Geophys. Res., 97:6683-6698.

Hyndman, R.D., Spence, G.D., Chapman, N.R., Riedel, M., and Edwards, R.N., 2001. Geophysical studies of marine gas hydrate in northern Cascadia. In Paull, C.K., and Dillon, W.P. (Eds.), Natural Gas Hydrates, Occurrence, Distribution and Detection. Geophys. Monogr., 124:273-295.

Hyndman, R.D., and Wang, K., 1993. Thermal constraints on the zone of major thrust earthquake failure: the Cascadia subduction zone. J. Geophys. Res., 98:2039-2060.

Jarrard, R.D., MacKay, M.E., Westbrook, G.K., and Screaton, E.J., 1995. Log-based porosity of ODP sites on the Cascadia accretionary prism. In Carson, B., Westbrook, G.K., Musgrave, R.J., and Suess, E. (Eds.), Proc. ODP, Sci. Results, 146 (Pt 1): College Station, TX (Ocean Drilling Program), 313-335.

Kastner, M., Kvenvolden, K.A., Whiticar, M.J., Camerlenghi, A., and Lorenson, T.D., 1995. Relation between pore fluid chemistry and gas hydrate associated with bottom-simulating reflectors at the Cascadia margin, Sites 889 and 892, Proc. ODP, Sci. Results, 146 (Pt 1): College Station, TX (Ocean Drilling Program), 175-187.

Kvenvolden, K.A., 1988. Methane hydrate-a major reservoir of carbon in the shallow geosphere? Chem. Geol., 71:41-51. doi:10.1016/0009-2541(88)90104-0

Lee, M.W., Hutchinson, D.R., Dillon, W.P., Miller, J.J., Agena, W.F., and Swift, B.A., 1993. Method of estimating the amount of in situ gas hydrates in deep marine sediments. Mar. Pet. Geol., 10(5):493-506. doi:10.1016/ 0264-8172(93)90050-3

Lorenson, T.D., and the Leg 164 Shipboard Scientific Party, 2000. Graphic summary of gas hydrate occurrence by proxy measurements across the Blake Ridge, Sites 994, 
995, and 997. In Paull, C.K., Matsumoto, R., Wallace, P.J., and Dillon, W.P. (Eds.), Proc. ODP, Sci. Results, 164: College Station, TX (Ocean Drilling Program), 247-249. [HTML]

MacKay, M.E., Jarrard, R.D., Westbrook, G.K., and Hyndman, R.D., 1994. Origin of bottom-simulating reflectors: geophysical evidence from the Cascadia accretionary prism. Geology, 22(5):459-462. doi:10.1130/0091-7613(1994)022<0459:OOB$\mathrm{SRG}>2.3 . \mathrm{CO} ; 2$

Milkov, A.V., Dickens, G.R., Claypool, G.E., Lee, Y.-J., Borowski, W.S., Torres, M.E., Xu, W., Tomaru, H., Tréhu, A.M., and Schultheiss, P., 2004. Co-existence of gas hydrate, free gas, and brine within the regional gas hydrate stability zone at Hydrate Ridge (Oregon margin): evidence from prolonged degassing of a pressurized core. Earth Planet. Sci. Lett., 222:829-843. doi:10.1016/j.epsl.2004.03.028

Paull, C.K., and Matsumoto, R., 2000. Leg 164 overview. In Paull, C.K., Matsumoto, R., Wallace, P.J., and Dillon, W.P. (Eds.), Proc. ODP, Sci. Results, 164: College Station, TX (Ocean Drilling Program), 3-10. [HTML]

Paull, C.K., Matsumoto, R., Wallace, P.J., et al., 1996. Proc. ODP, Init. Repts., 164: College Station, TX (Ocean Drilling Program).

Paull, C.K., and Ussler, W., III, 1997. Are low salinity anomalies below BSRs a consequence of interstitial gas bubble barriers? Eos, Trans. Am. Geophys. Union, 78:F339.

Pettigrew, T.L., 1992. The design and operation of a wireline pressure core sampler (PCS). ODP Tech. Note, 17.

Pohlman, J.W., Canuel, E.A., Chapman, N.R., Spence, G.D., Whiticar, M.J., and Coffin, R.B., 2005. The origin of thermogenic gas hydrates on the northern Cascadia margin as inferred from isotopic $\left({ }^{13} \mathrm{C} /{ }^{12} \mathrm{C}\right.$ and $\left.\mathrm{D} / \mathrm{H}\right)$ and molecular composition of hydrate and vent gas. Org. Geochem., 36:703-716. doi:10.1016/ j.orggeochem.2005.01.011

Riddihough, R.P., 1984. Recent movements of the Juan de Fuca plate system. J. Geophys. Res., 89:6980-6994.

Riedel, M., 2001. 3D seismic investigations of northern Cascadia marine gas hydrates [Ph.D. dissert.]. Univ. Victoria, Canada.

Riedel, M., Collett, T.S., and Hyndman, R.D. 2005. Gas hydrate concentration estimates from chlorinity, electrical resistivity, and seismic velocity. Geol. Surv. Can. Open-File Rep., 4934.

Riedel, M., Novosel, I., Spence, G.D., Hyndman, R.D., Chapman, N.R., and Lewis, T., 2006. Geophysical and geochemical signatures associated with gas hydraterelated venting in the northern Cascadia margin. Geol. Soc. Am. Bull., 118(1-2).

Riedel, M., Spence, G.D., Chapman, N.R., and Hyndman, R.D., 2002. Seismic investigations of a vent field associated with gas hydrates, offshore Vancouver Island. J. Geophys. Res., 107(B9). doi:10.1029/2001JB000269

Shipley, T.H., Houston, M.H., Buffler, R.T., Shaub, F.J., McMillen, K.J., Ladd, J.W., and Worzel, J.L., 1979. Seismic evidence for widespread possible gas hydrate hori- zons on continental slopes and rises. AAPG Bull., 63:2204-2213.

Solem, R.C., Spence, G.D., Vukajlovich, D., Hyndman, R.D., Riedel, M., Novosel, I., and Kastner, M., 2002. Methane advection and gas hydrate formation within an active vent field offshore Vancouver Island. Fourth Int. Conf. Gas Hydrates: Yokohama, Japan, 19023.

Spence, G.D., Hyndman, R.D., Chapman, N.R., Riedel, M., Edwards, N., and Yuan, J., 2000. Cascadia margin, northeast Pacific Ocean: hydrate distribution from geophysical investigations. In Max, M.D. (Ed.), Natural Gas Hydrate in Ocean and Permafrost Environments: New York (Kluwer Academic Publisher).

Taylor, A.E., Dallimore, S.D., Hyndman, R.D., and Wright, F., 2002. Comparing the sensitivity of terrestrial and marine gas hydrates to climate warming at the end of the last ice age. Fourth Int. Conf. Gas Hydrates: Yokohama, Japan, 19023.

Teichert, B.M.A., Torres, M.E., Bohrmann, G., and Eisenhauer, A., 2005. Fluid sources, fluid pathways and diagenetic reactions across an accretionary prism revealed by Sr and B geochemistry. Earth Planet. Sci. Lett., 239:106121. doi:10.1016/j.epsl.2005.08.002

Torres, M.E., Teichert, B.M.A., Tréhu, A.M., Borowski, W.S., and Tomaru, H., 2004a. Relationship of pore water freshening to accretionary processes in the Cascadia margin: fluid sources and gas hydrate abundance. Geophys. Res. Lett., 31:L22305. doi:10.1029/2004GL021219

Torres, M.E., Wallmann, K., Tréhu, A.M., Bohrmann, G., Borowski, W.S., and Tomaru, H., 2004b. Gas hydrate growth, methane transport, and chloride enrichment at the southern summit of Hydrate Ridge, Cascadia margin off Oregon. Earth Planet. Sci. Lett., 226:225-241. doi:10.1016/j.epsl.2004.07.029

Tréhu, A.M., Bohrmann, G., Rack, F.R., Collett, T.S., Goldberg, D.S., Long, P.E., Milkov, A.V., Riedel, M., Schultheiss, P., Torres, M.E., Bangs, N.L., Barr, S.R., Borowski, W.S., Claypool, G.E., Delwiche, M.E., Dickens, G.R., Gracia, E., Guerin, G., Holland, M., Johnson, J.E., Lee, Y.-J., Liu, C.-S., Su, X., Teichert, B., Tomaru, H., Vanneste, M., Watanabe, M., and Weinberger, J.L., 2004. Three-dimensional distribution of gas hydrate beneath southern Hydrate Ridge: constraints from ODP Leg 204. Earth Planet. Sci. Lett., 222(3-4):845-862. doi:10.1016/ j.eps1.2004.03.035

Tréhu, A.M., Bohrmann, G., Rack, F.R., Torres, M.E., et al., 2003. Proc. ODP, Init. Repts., 204 [CD-ROM]. Available from: Ocean Drilling Program, Texas A\&M University, College Station TX 77845-9547, USA. [HTML]

Tucholke, B.E., Bryan, G.M., and Ewing, J.I., 1977. Gashydrate horizons detected in seismic-profiler data from the western North Atlantic. AAPG Bull., 61:698-707.

Ussler, W., III, and Paull, C.K., 2001. Ion exclusion associated with marine gas hydrate deposits. In Paull, C.K., and Dillon, W.P. (Eds.), Natural Gas Hydrates: Occurrence, Distribution, and Detection. Geophys. Monogr., 124:4151.

von Huene, R., and Pecher, I.A., 1998. Vertical tectonics and the origins of BSRs along the Peru margin. Earth Planet Sci. Lett., 166(1-2):47-55. doi:10.1016/S0012821X(98)00274-X 
Westbrook, G.K., Carson, B., Musgrave, R.J., et al., 1994. Proc. ODP, Init. Repts., 146 (Pt. 1): College Station, TX (Ocean Drilling Program).

Wood, W.T., Gettrust, J.F., Chapman, N.R., Spence, G.D., and Hyndman, R.D., 2002. Decreased stability of methane hydrates in marine sediments owing to phaseboundary roughness. Nature (London, U. K.), 420:656660. doi:10.1038/nature01263

$\mathrm{Xu}, \mathrm{W} ., 2002$. Phase balance and dynamic equilibrium during formation and dissociation of methane gas hydrate. Fourth Int. Conf. Gas Hydrates: Yokohama, Japan, 19023:199-200.

$\mathrm{Xu}$, W., 2004. Modeling dynamic marine gas hydrate systems. Am. Mineral., 89:1271-1279.

$\mathrm{Xu}, \mathrm{W}$., and Ruppel, C., 1999. Predicting the occurrence, distribution, and evolution of methane gas hydrate in porous marine sediments. J. Geophys. Res, 104(B3):50815096. doi:10.1029/1998JB900092

Yuan, J., and Edwards, R.N., 2000. The assessment of marine gas hydrates through electrical remove sound- ing: hydrate without a BSR? Geophys. Res. Lett., 27(16):2397-2400. doi:10.1029/2000GL011585

Yuan, T., Hyndman, R.D., Spence, G.D., and Desmons, B., 1996. Seismic velocity increase and deep-sea gas hydrate concentration above a bottom-simulating reflector on the northern Cascadia continental slope. J. Geophys. Res., 101(B6):13655-13671. doi:10.1029/96JB00102

Yuan, T., Spence, G.D., Hyndman, R.D., Minshull, T.A., and Singh, S.C., 1999. Seismic velocity studies of a gas hydrate bottom-simulating reflector on the northern Cascadia continental margin: amplitude modeling and full waveform inversion. J. Geophys. Res., 104(B1):11791192. doi:10.1029/1998JB900020

Zühlsdorff, L., and Spiess, V., 2004. Three-dimensional seismic characterization of a venting site reveals compelling indications of natural hydraulic fracturing. Geology, 32(2):101-104. doi:10.1130/G19993.1

Publication: 28 October 2006

MS 311-101 
Figure F1. General location of drilling transect near previous ODP Sites 889/890. A bottom-simulating reflector is present on $\sim 50 \%$ of the midcontinental slope (shaded area).

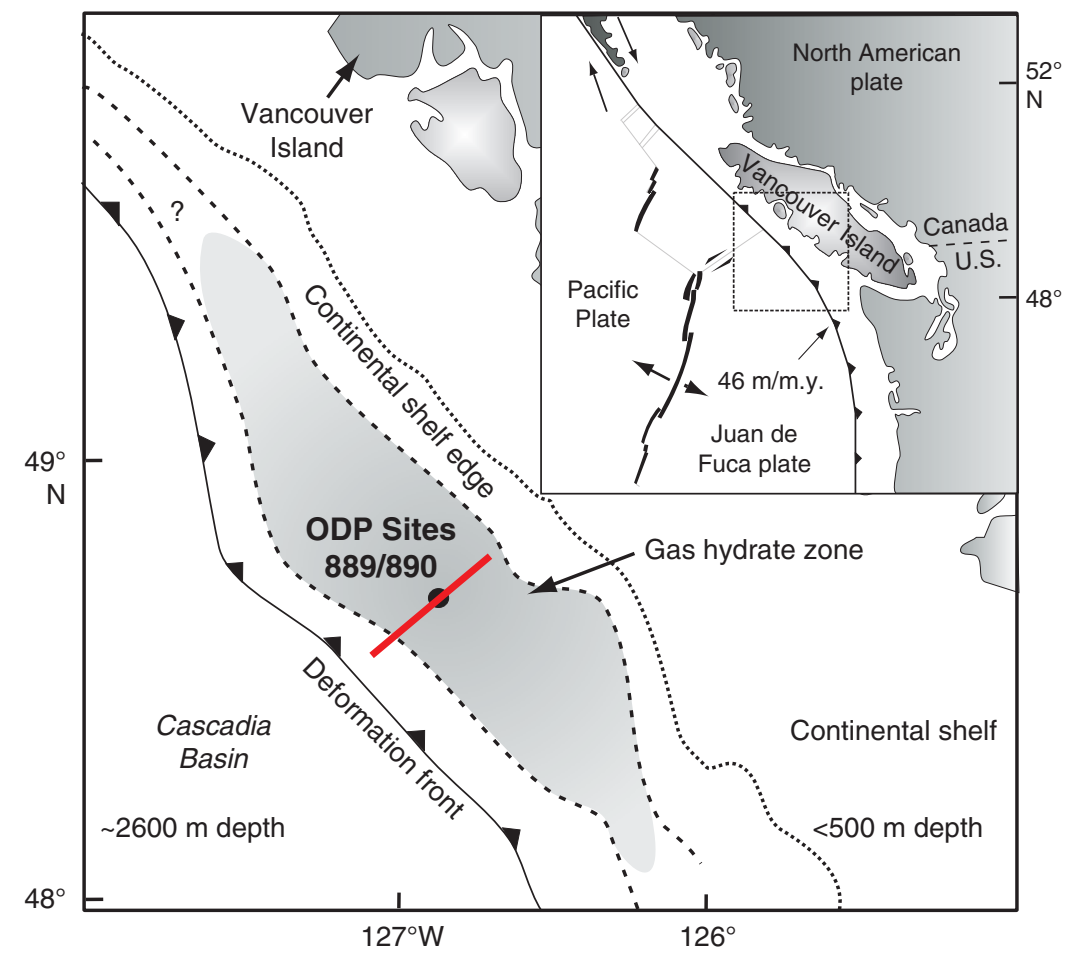


Figure F2. Marine gas hydrate cycle (after Hyndman and Davis, 1992). BSR = bottom-simulating reflector.

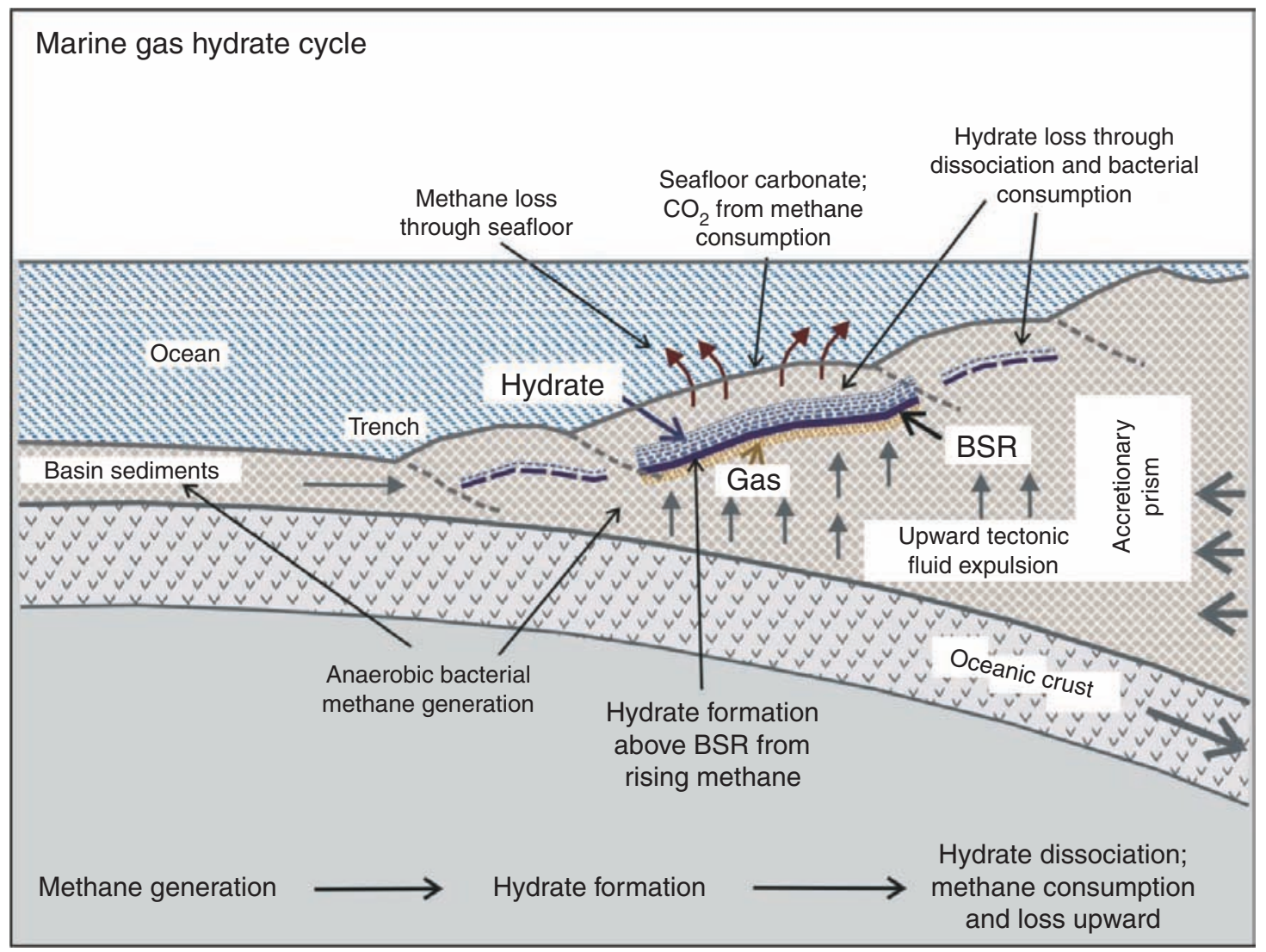


Figure F3. Overview of MCS Line 89-08 across the northern Cascadia margin showing the transect with the four transect sites cored during Expedition 311 (Sites U1326, U1325, U1327, and U1328) as well as proposed basin reference Site CAS-04B. The cold vent Site U1328 (proposed Site CAS-06A) is $\sim 2 \mathrm{nmi}$ off this line toward the southeast.

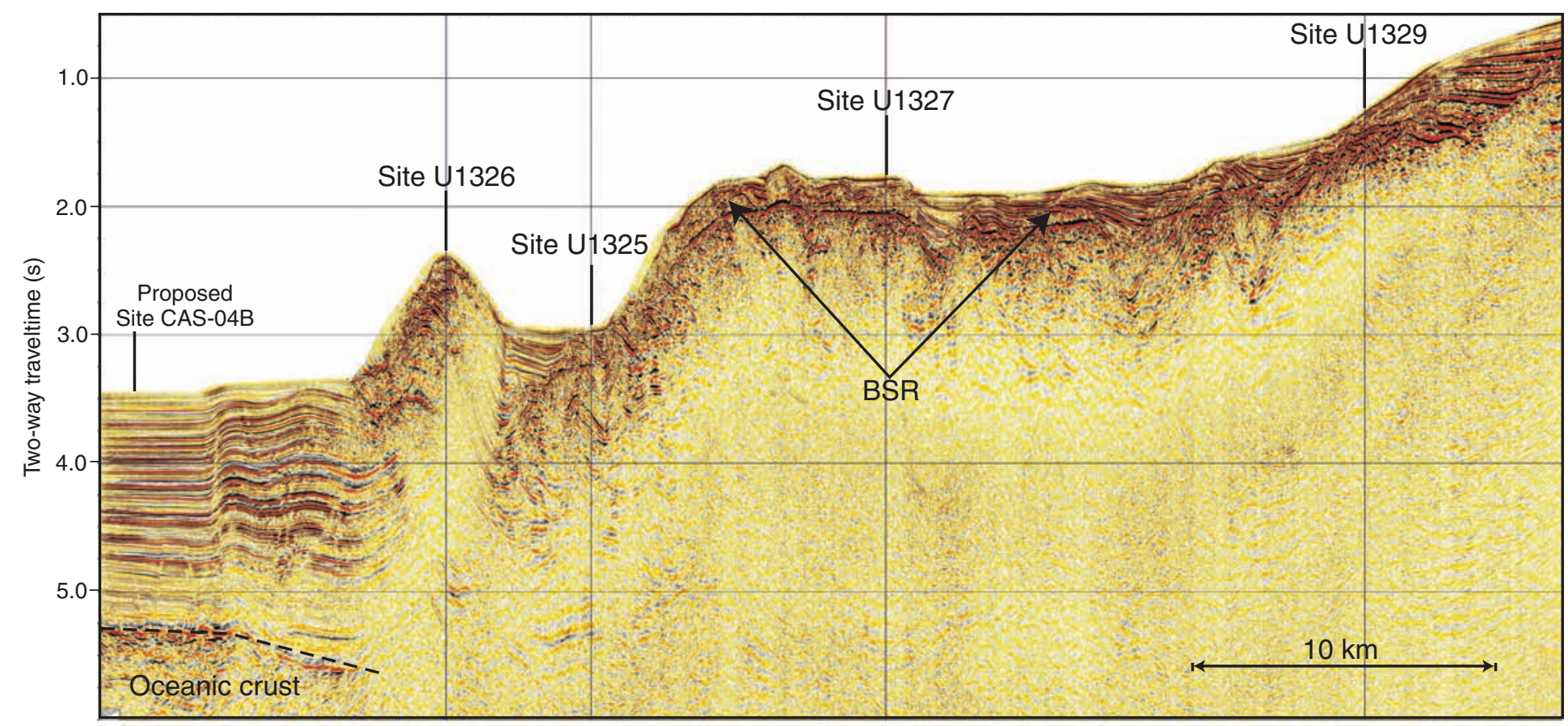


Figure F4. Multibeam bathymetry map along the transect across the accretionary prism offshore Vancouver Island (courtesy of D. Kelley, J. Delaney, and D. Glickson, University of Washington, and C. Barnes, C. Katnick, NEPTUNE Canada, University of Victoria; funded by the University of Washington and the W.M. Keck Foundation). MCS = multichannel seismic.

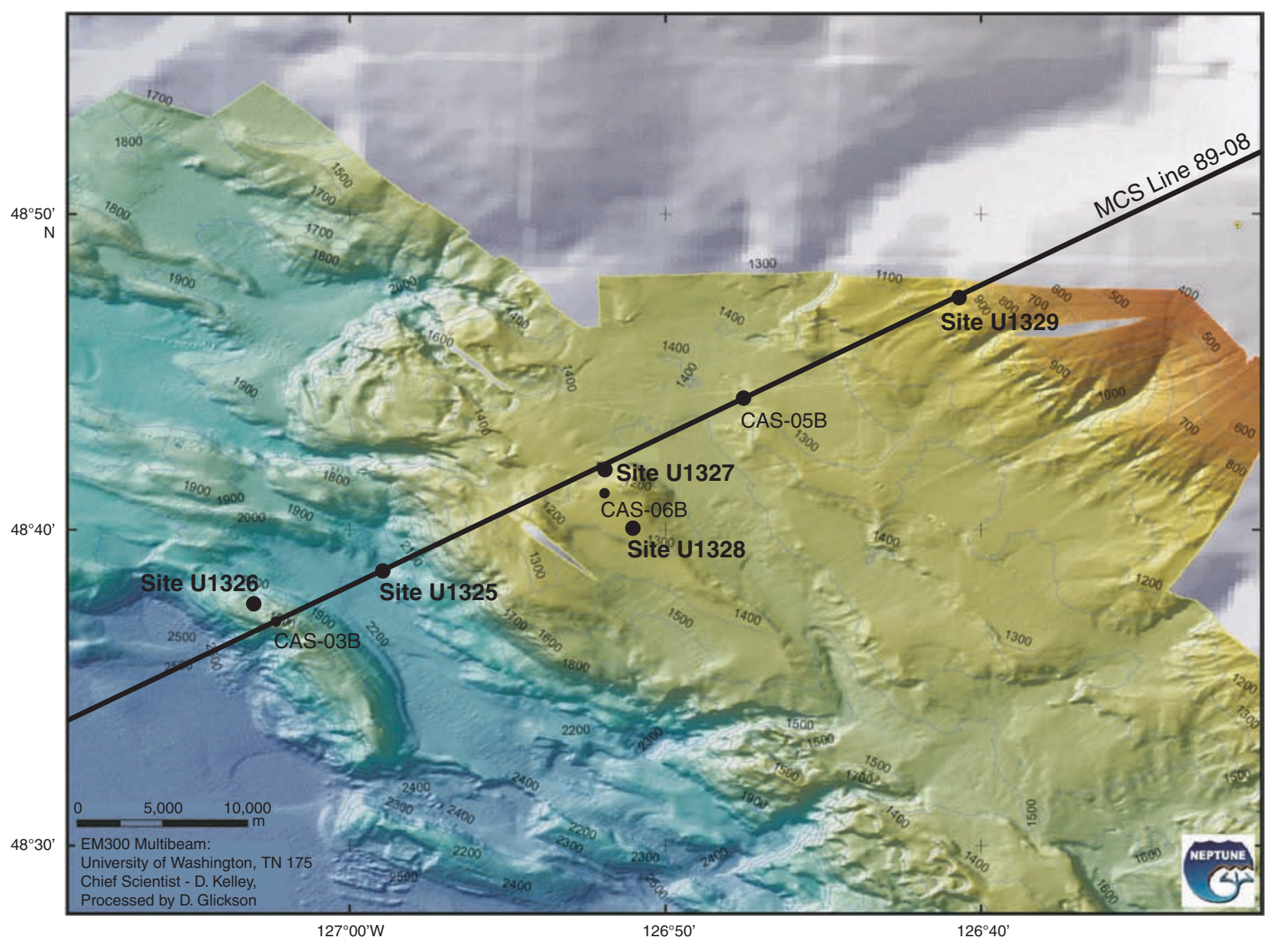


Figure F5. Multibeam bathymetry map over first accreted ridge documenting the collapse feature around Site U1326. Linear features, identified as faults from seismic data, cross the ridge in the central part (courtesy of D. Kelley, J. Delaney, and D. Glickson, University of Washington, and C. Barnes, C. Katnick, NEPTUNE Canada, University of Victoria; funded by the University of Washington and the W.M. Keck Foundation).

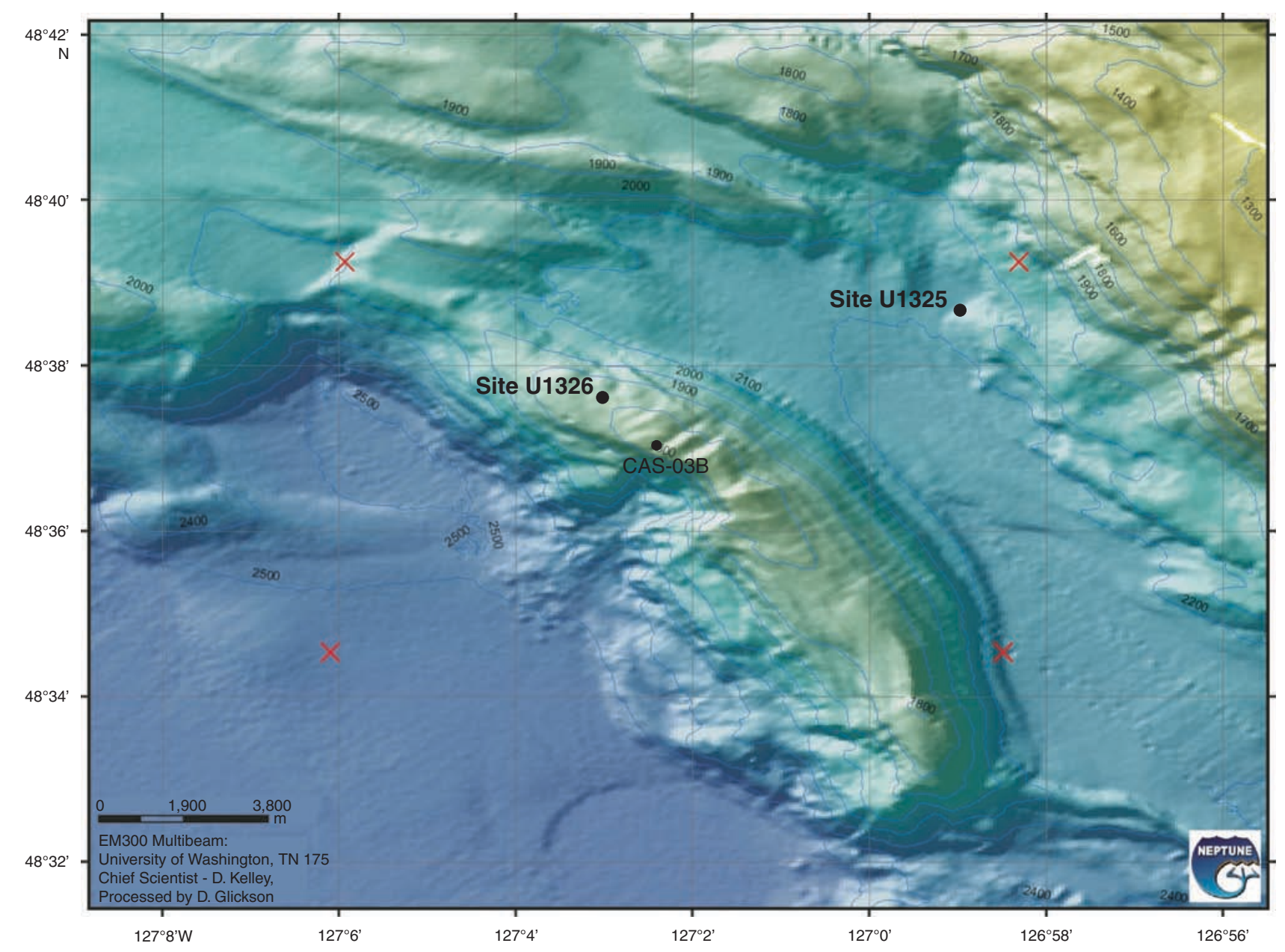


Figure F6. Summary of Expedition 311 measured borehole fluid pressure (dP) profiles with the best-fit linear trend subtracted. Annular pressure while drilling (APWD) data were the primary measurement used for gas monitoring during LWD/MWD drilling.

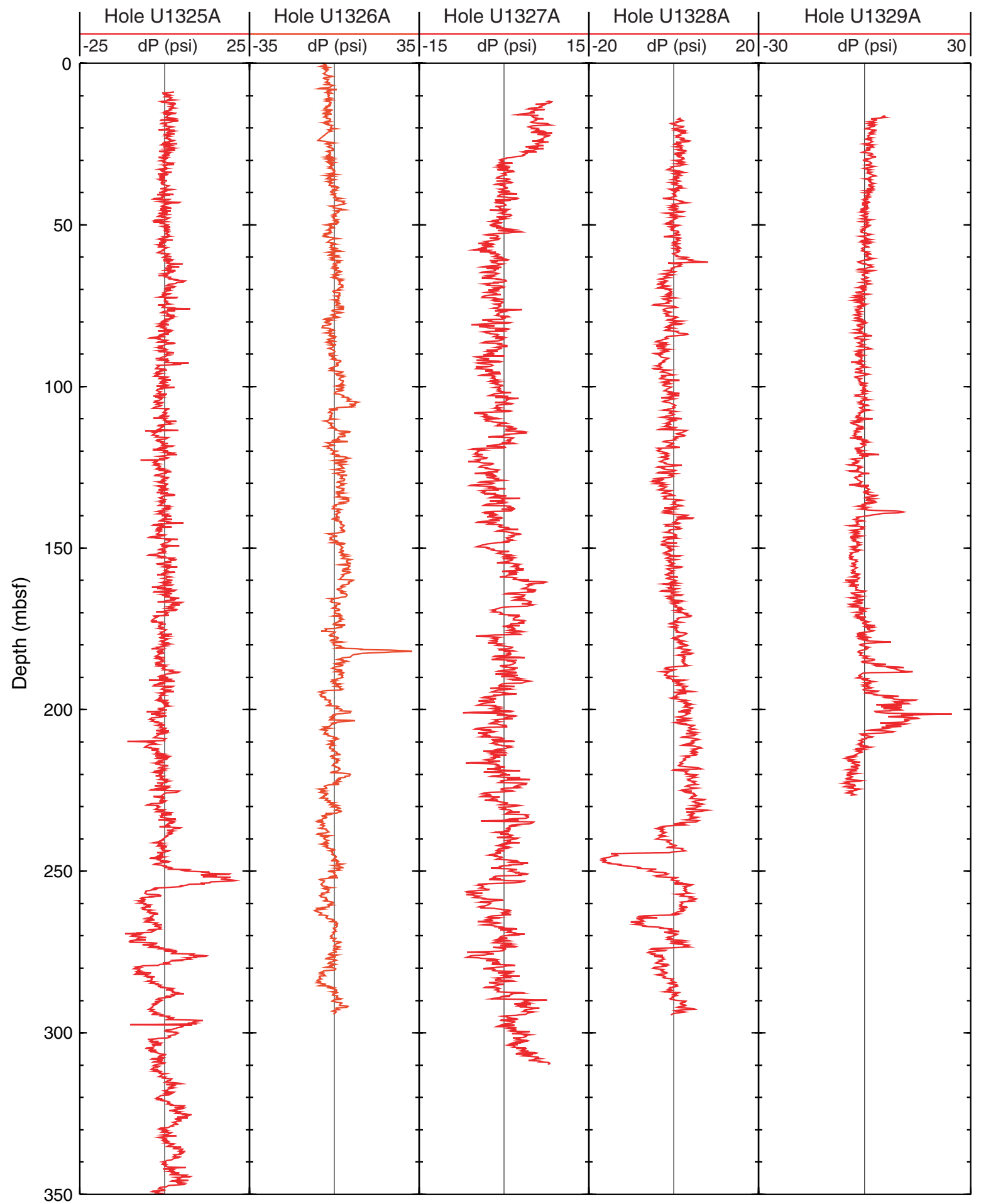


Figure F7. Section of MCS Line 89-08 over Site U1325. The data are of low seismic frequency from 10 to $60 \mathrm{~Hz}$. A buried ridge of accreted sediments can be identified between common depth points (CDPs) 1320 and 1440, covered by a thin interval of slope-basin-type sediments that form onlaps onto the ridge. Underneath the center of the ridge a bright spot is identified, potentially indicating the presence of free gas. A strong bottom-simulating reflector (BSR) is seen over much of the eastern section of the basin, whereas it disappears underneath the western part of the basin, filled with as much as $600 \mathrm{~ms}$ TWT thick slope-basin-type sediments. Site U1325 intersects an interval of 300 ms TWT thickness where sediments show strong eastward dip. Note the boundary between lithostratigraphic Subunits IA and IB is traceable for $\sim 1.5 \mathrm{~km}$ around Site U1325. Several small-scale faults are visible, one of which was most likely penetrated at Site U1325 near the base of lithostratigraphic Unit II. V.E $=$ vertical exaggeration.

SW

1300

CDP

1350

1400

NE

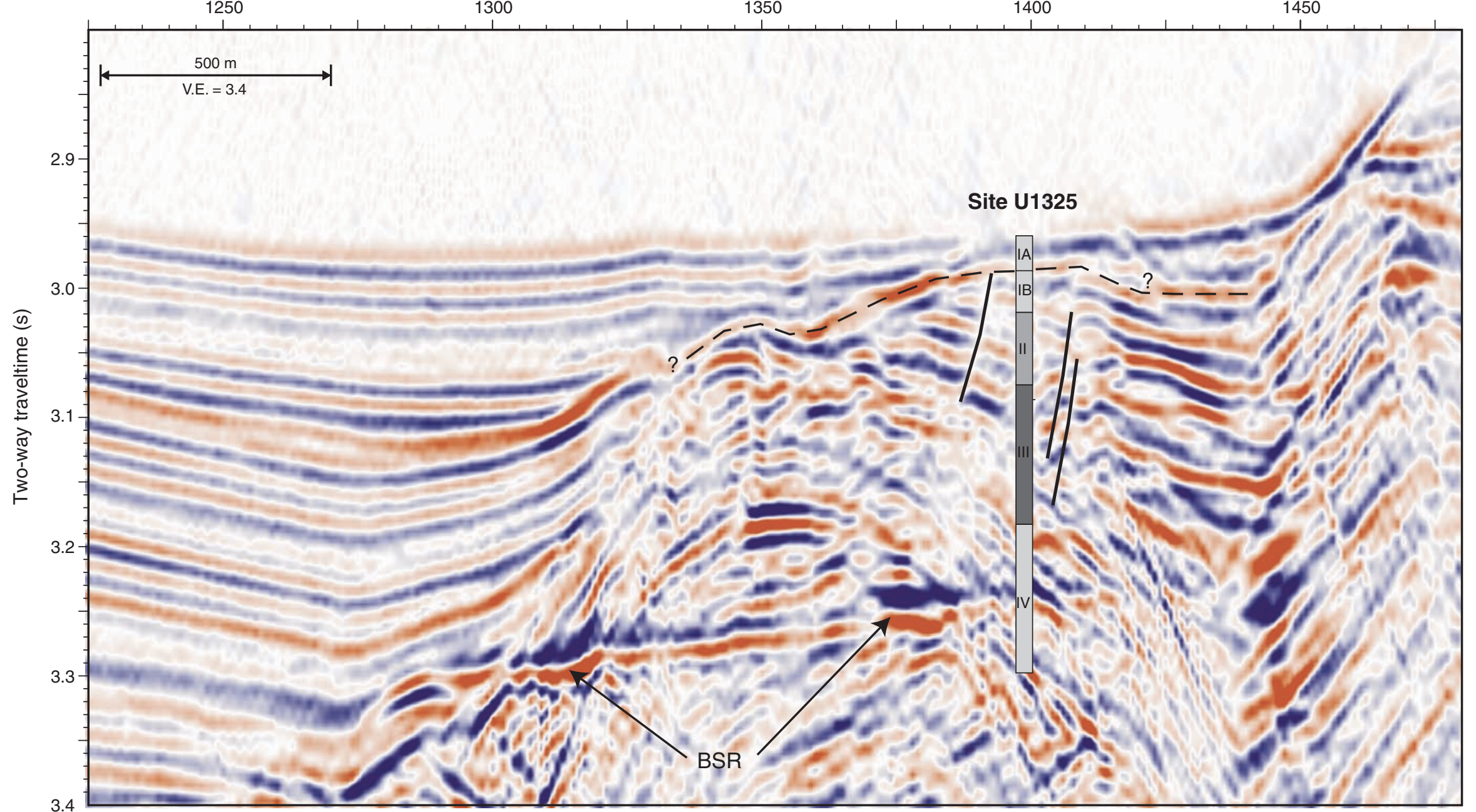


Figure F8. Comparison of seismic data from MCS Line 89-08 nearest to Site U1325 and main logging- and core-derived measurements (porosity from LWD/MWD and MAD data, resistivity-at-the-bit [RAB] image from LWD/MWD deployment, chlorinity of interstitial water samples, $\mathrm{C}_{1} / \mathrm{C}_{2}$ ratio of the void gas, and pore water saturation $\left[S_{w}\right]$ from LWD/MWD resistivity data). Solid triangle $=$ seawater $\mathrm{Cl}, \mathrm{CDP}=\mathrm{common}$ depth point, $\mathrm{BSR}=$ bottom-simulating reflector, V.E. = vertical exaggeration.

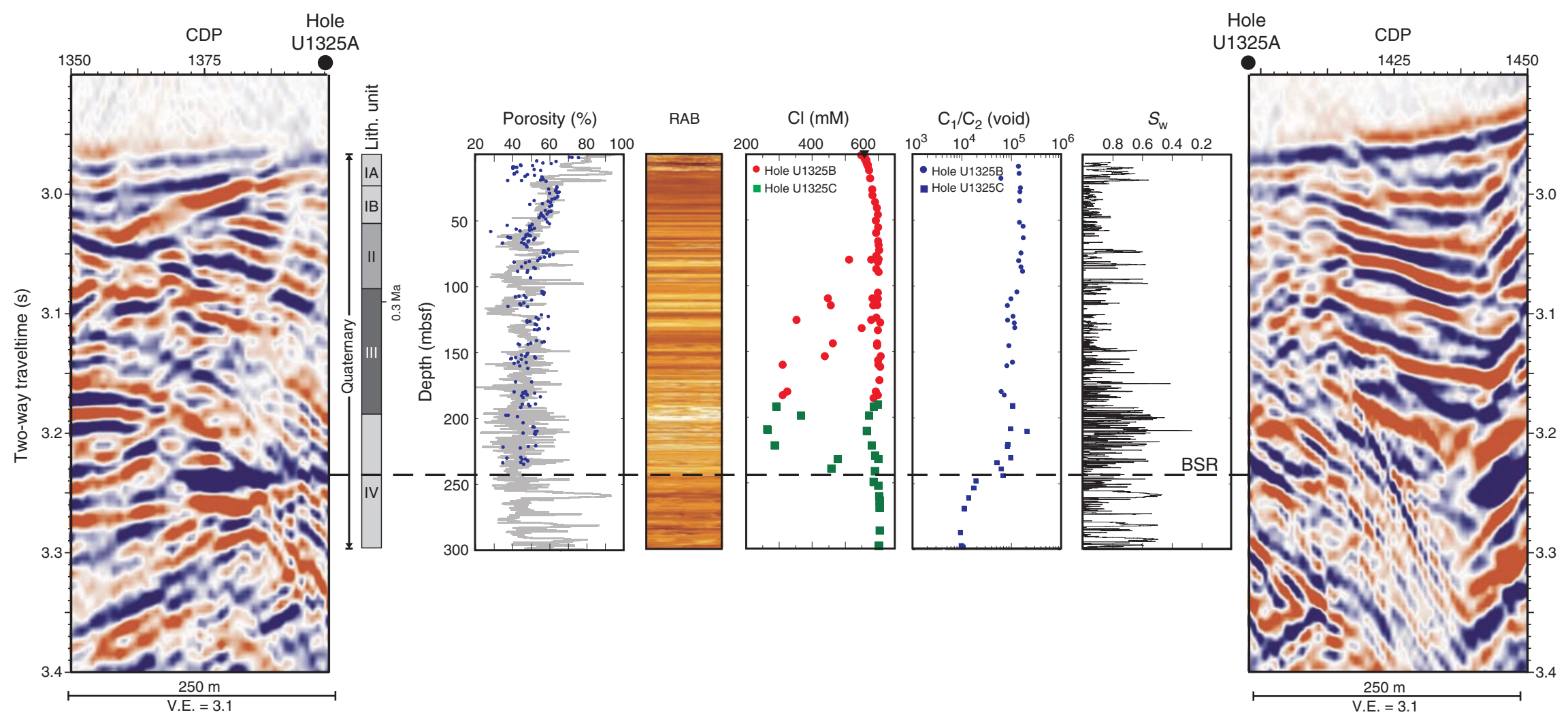


Figure F9. Comparison of seismic data from MCS Line PGC9902_ODP7 (twice the frequency content of MCS Line 89-08) nearest to Site U1325 and main logging- and core-derived measurements (porosity from LWD/MWD and MAD data, resistivity-at-the-bit [RAB] image from LWD/MWD deployment, chlorinity of interstitial water samples, $\mathrm{C}_{1} / \mathrm{C}_{2}$ ratio of the void gas, and pore water saturation $\left[S_{\mathrm{w}}\right]$ from LWD/MWD resistivity data). Solid triangle $=$ seawater $\mathrm{Cl}, \mathrm{CDP}=$ common depth point, $\mathrm{BSR}=$ bottom-simulating reflector, V.E. $=$ vertical exaggeration .
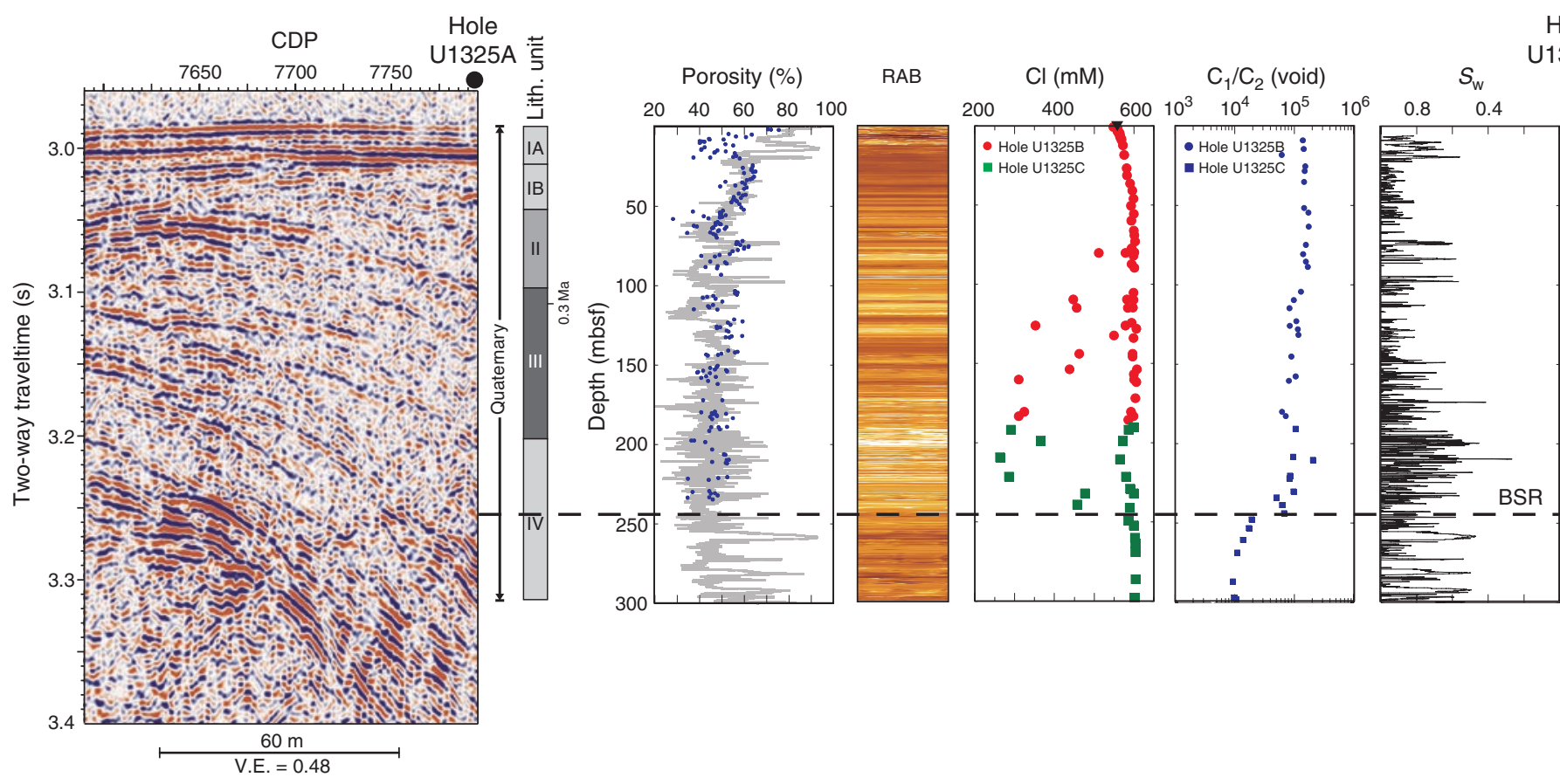

300

V.E. $=0.48$

Hole

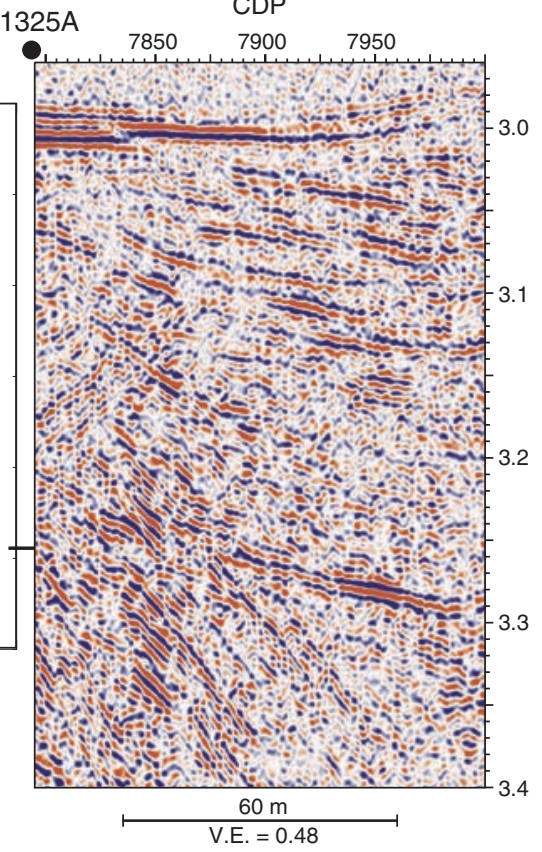


Figure F10. Section from MCS Line PGC9902_CAS03_MCS from the 1999 survey over Site U1326. The bottom-simulating reflector (BSR) is clearly visible. Also shown are deep faults related to apparent normal faulting at the surface CDP $=$ common depth point, V.E. $=$ vertical exaggeration.

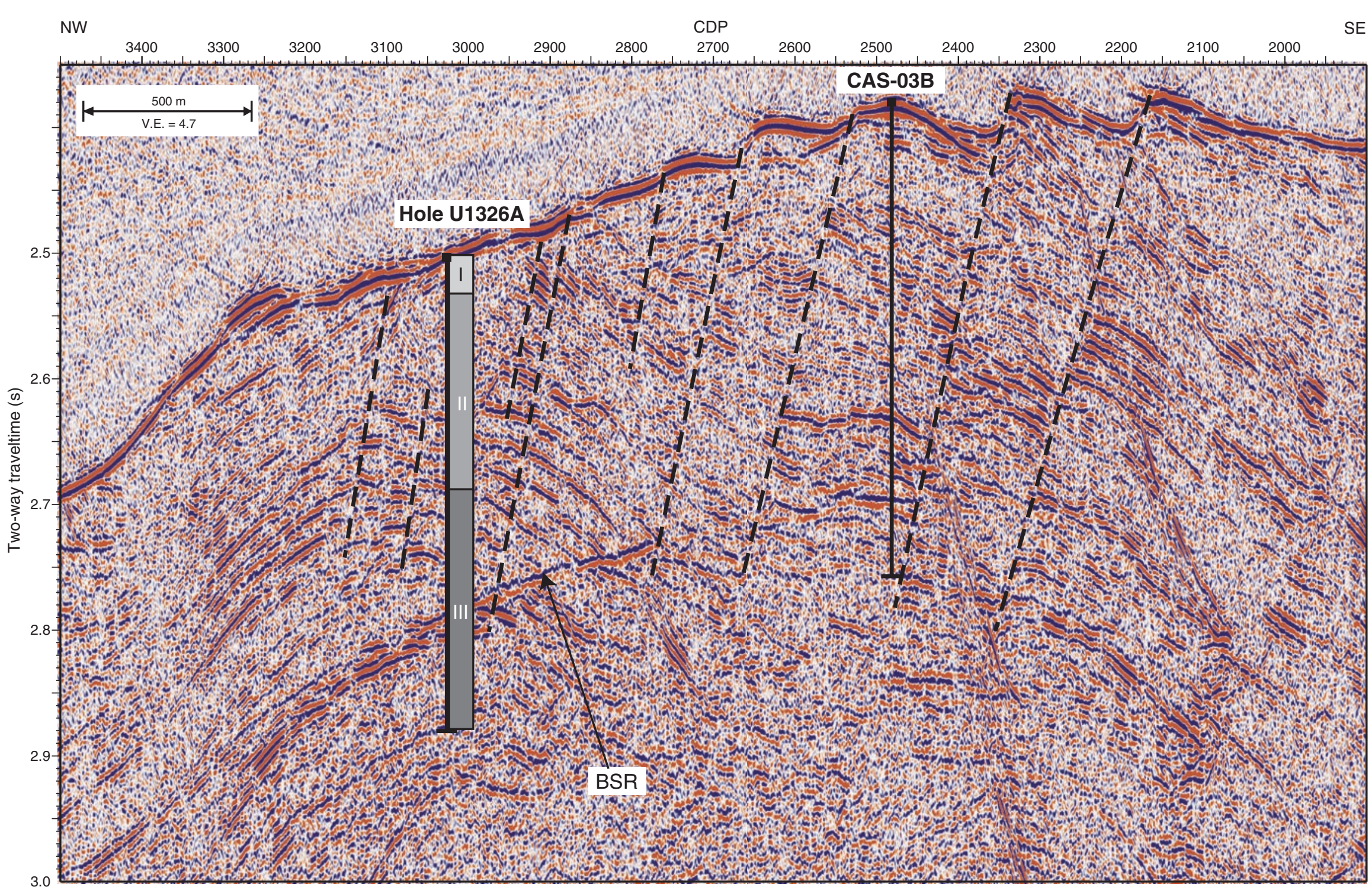


Figure F11. Section from SCS Line PGC0408_CAS03B_X03 crossing Site U1326. A bottom-simulating reflector (BSR) is visible, but almost no coherent reflectivity is identified. $\mathrm{CDP}=$ common depth point, V.E. = vertical exaggeration.

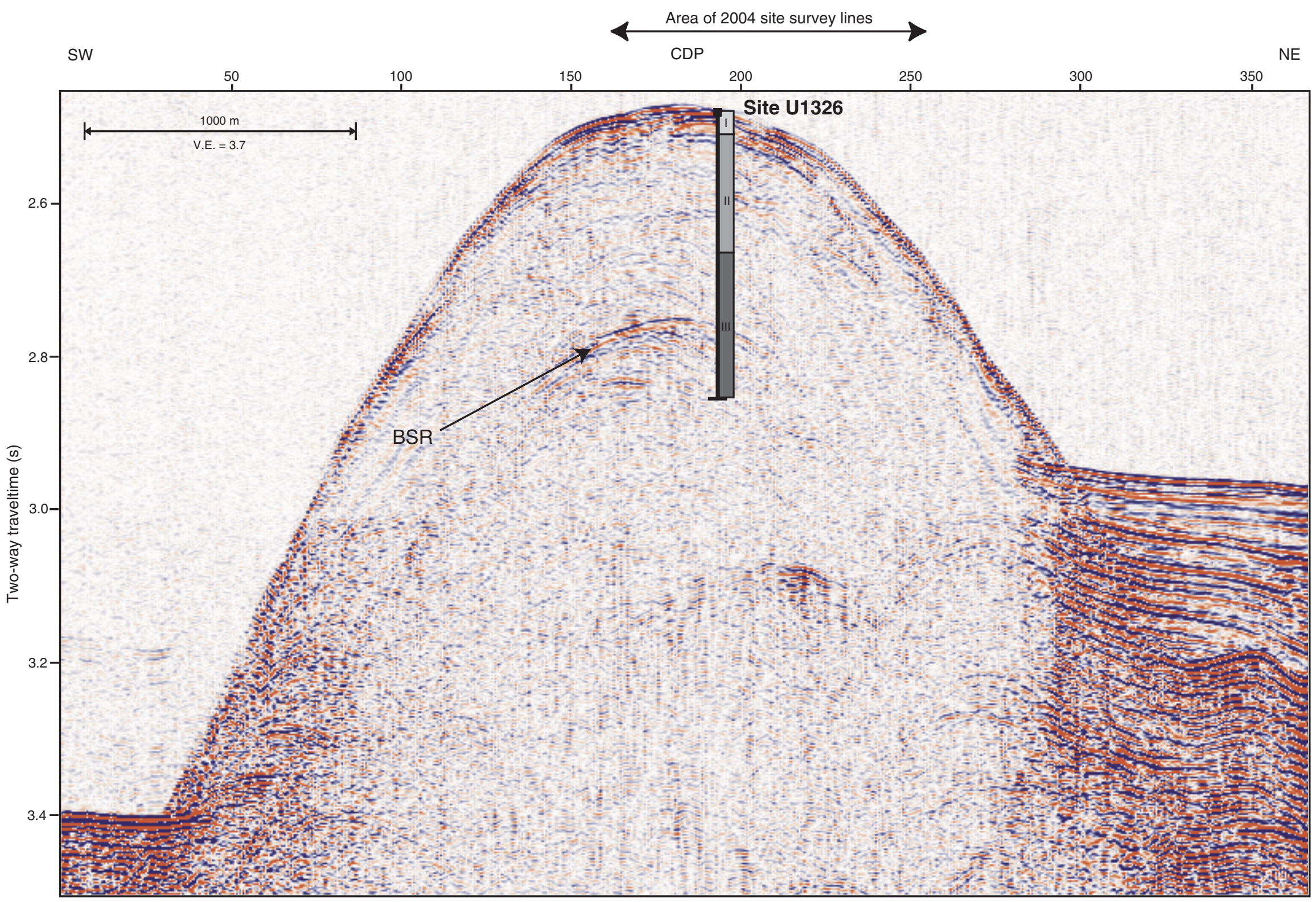


Figure F12. Section from MCS Line 89-08 over Site U1326 from Leg 146 presite survey showing in low-frequency data the strong bottom-simulating reflector (BSR) underneath the center of the ridge. The asymmetric deformation of the ridge is also seen by strong changes in coherent seismic reflectivity from southwest to northeast. $\mathrm{CDP}=$ common depth point, V.E. = vertical exaggeration.

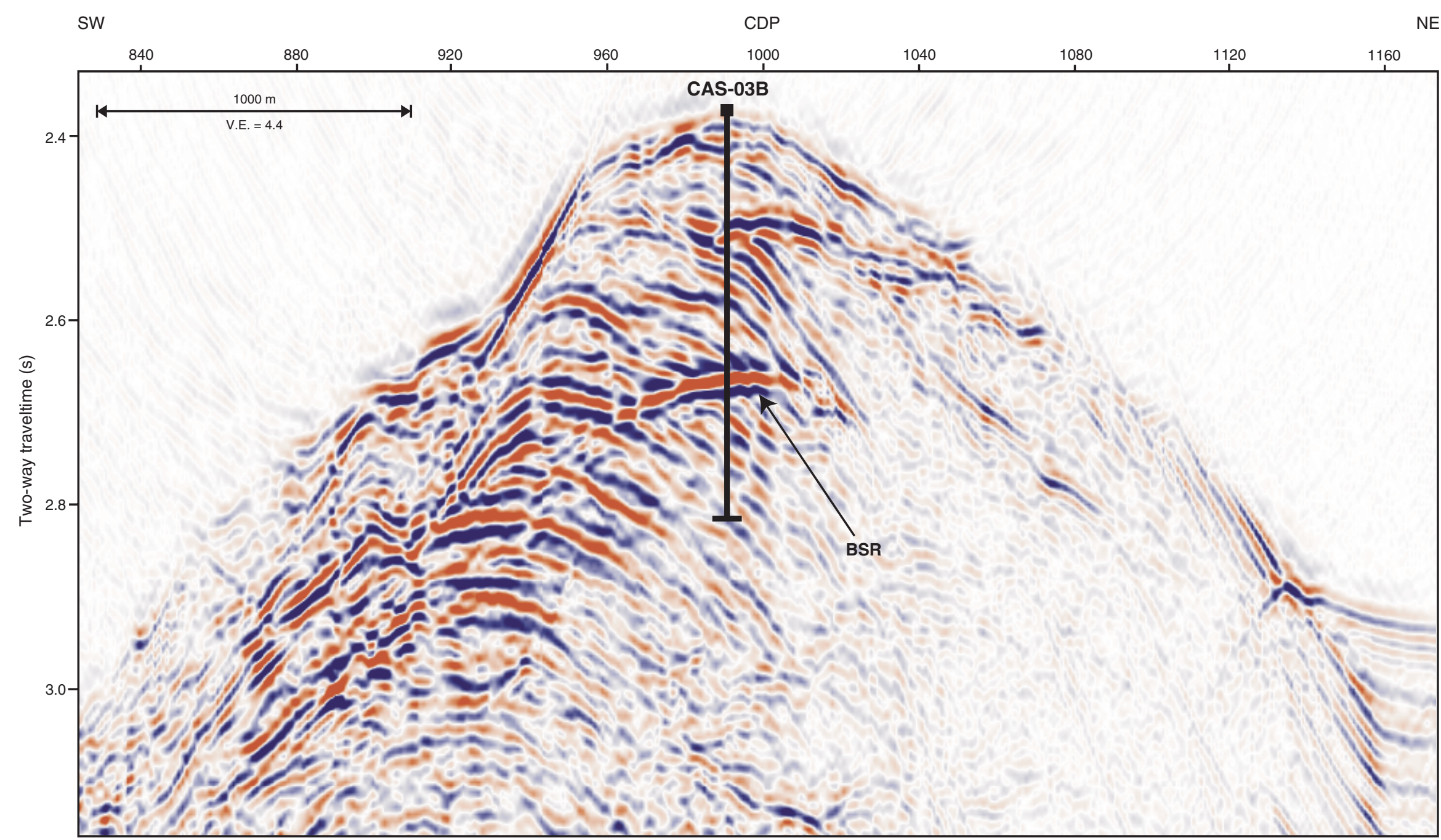


Figure F13. Comparison of seismic data from MCS Line PGC9902_CAS03_MCS and key data from Site U1326, including lithostratigraphic units (Holes U1326C and U1326D), porosity from LWD/MWD data (Hole U1326A) and MAD data (Holes U1326C and U1326D), resistivity-at-the-bit (RAB) data from LWD/MWD (Hole U1326A), interstitial water chlorinity (Holes U1326C and U1326D), $\mathrm{C}_{1} / \mathrm{C}_{2}$ ratio (Holes U1326C and U1326D), and pore water saturation $\left(S_{\mathrm{w}}\right)$ from LWD data (Hole U1326A). The bright band of high electrical reflectivity as seen in the RAB image (identified in Hole U1326A) does not correlate to a prominent seismic event. Solid triangle $=$ seawater $\mathrm{Cl}, \mathrm{CDP}=$ common depth point, $\mathrm{GH}=\mathrm{gas}$ hydrate, PCS = pressure core sampler, BSR = bottom-simulating reflector, V.E. = vertical exaggeration

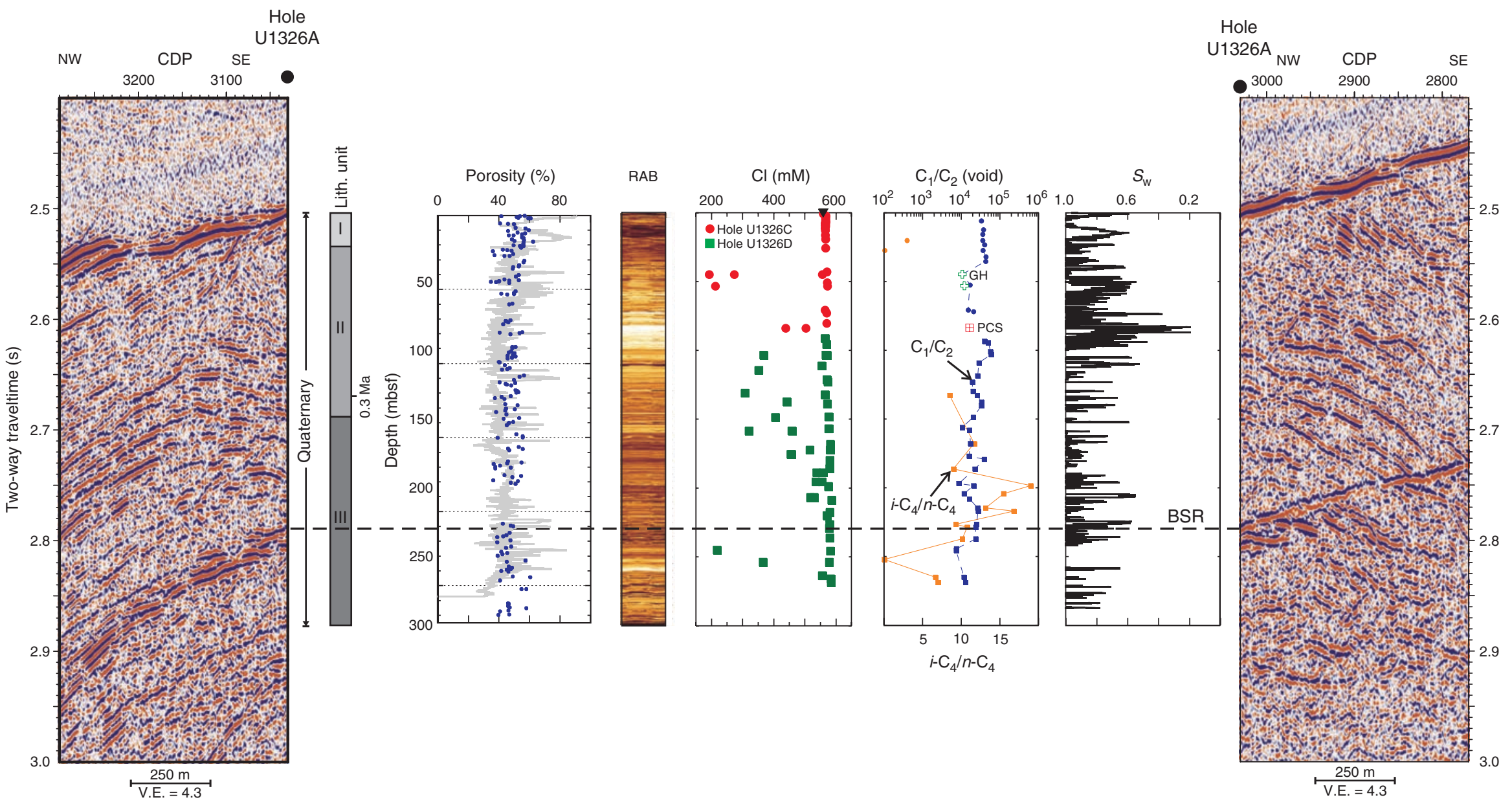


Figure F14. Bathymetric map of the seafloor near Site U1327 (courtesy of V. Spiess, Sonne cruise 111). The bathymetry is dominated by two topographic highs that rise to $\sim 200 \mathrm{~m}$ above surrounding seafloor. MCS = multichannel seismic.

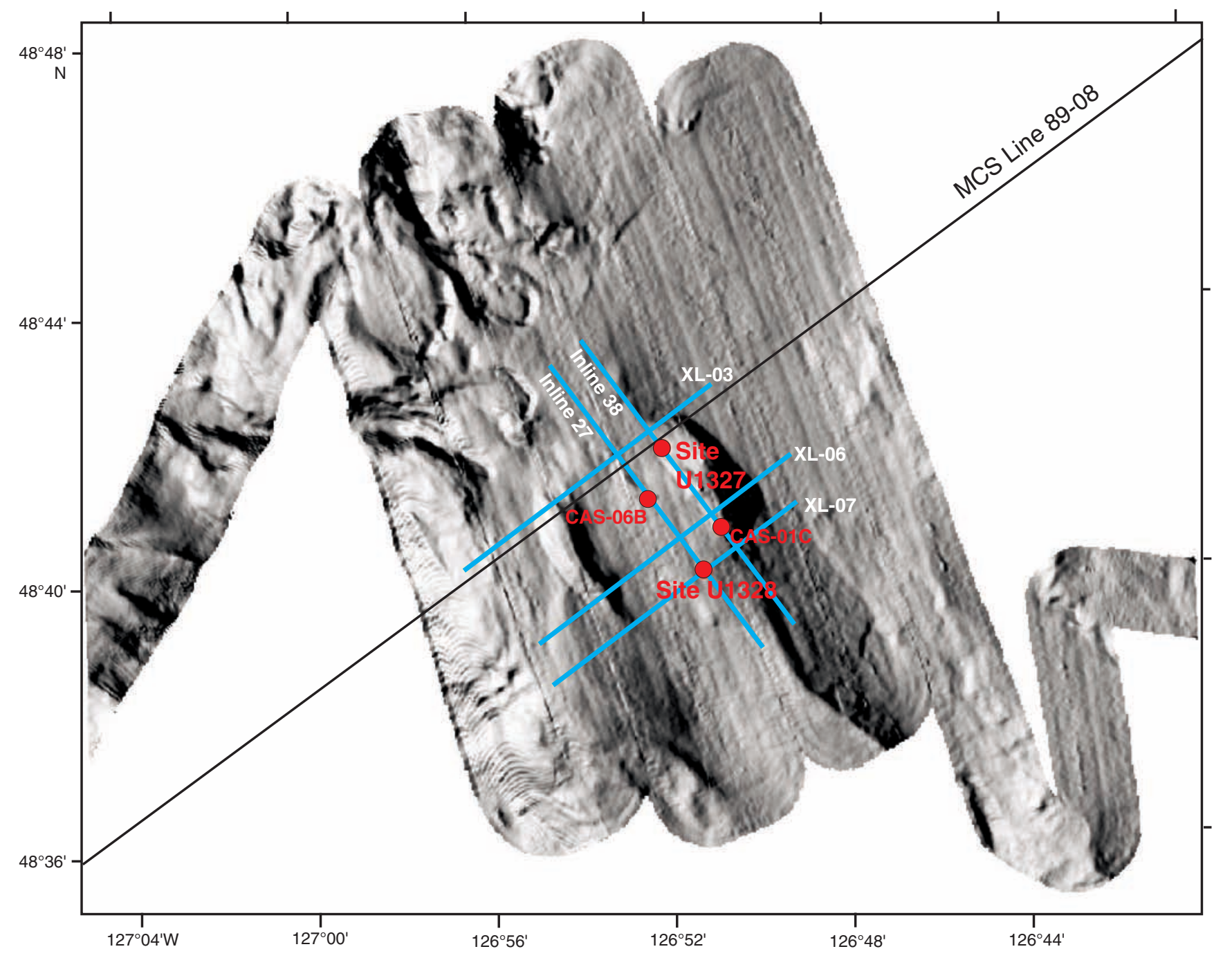


Figure F15. Section from Inline 38 from the 1999 3-D MCS survey over Site U1327. The bottom-simulating reflector (BSR) is clearly visible. The boundary between slope sediments and incoherent accreted sediments is indicated by a dashed line. This boundary is often gradational. V.E. = vertical exaggeration.

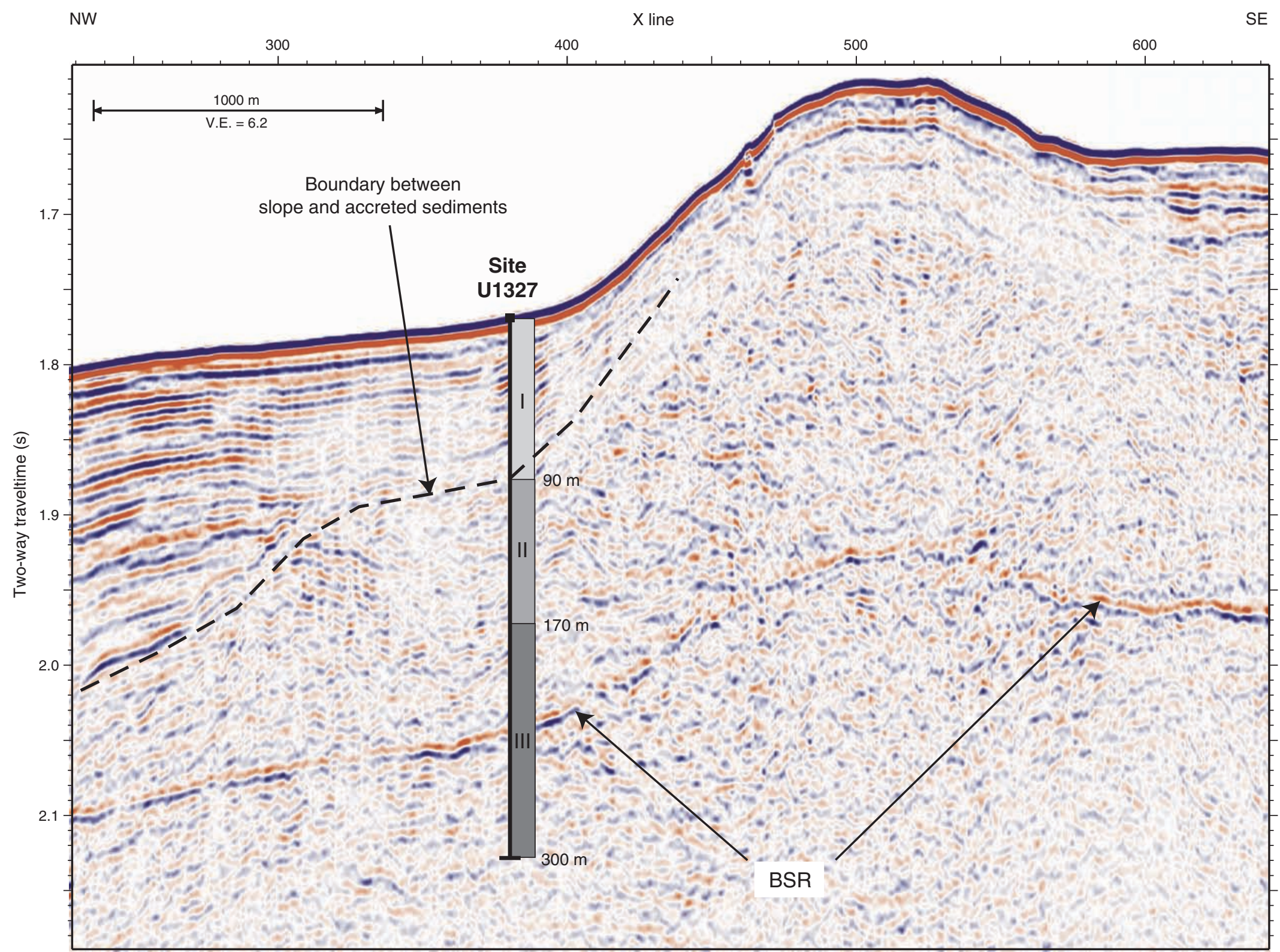


Figure F16. Comparison of seismic data from Inline 38 and key data from Site U1327, including lithostratigraphic units (Hole U1327C), porosity from LWD/MWD data (Hole U1327A) and MAD data (Hole U1327C), resistivity-at-the-bit (RAB) data from LWD/MWD (Hole U1327A), interstitial water chlorinity (Hole U1327C), $\mathrm{C}_{1} / \mathrm{C}_{2}$ ratio (Hole U1327C), and pore water saturation $\left(S_{\mathrm{w}}\right)$ from LWD data (Hole U1327C). Note that there is an offset of $\sim 15 \mathrm{~m}$ between Holes U1327A and U1327C in a direction perpendicular to the orientation of Inline 38 . The bright band of high electrical reflectivity as seen in the RAB image (identified in Hole U1327A) does not correlate to a prominent seismic event. PCS $=$ pressure core sampler, BSR = bottom-simulating reflector, V.E. = vertical exaggeration.

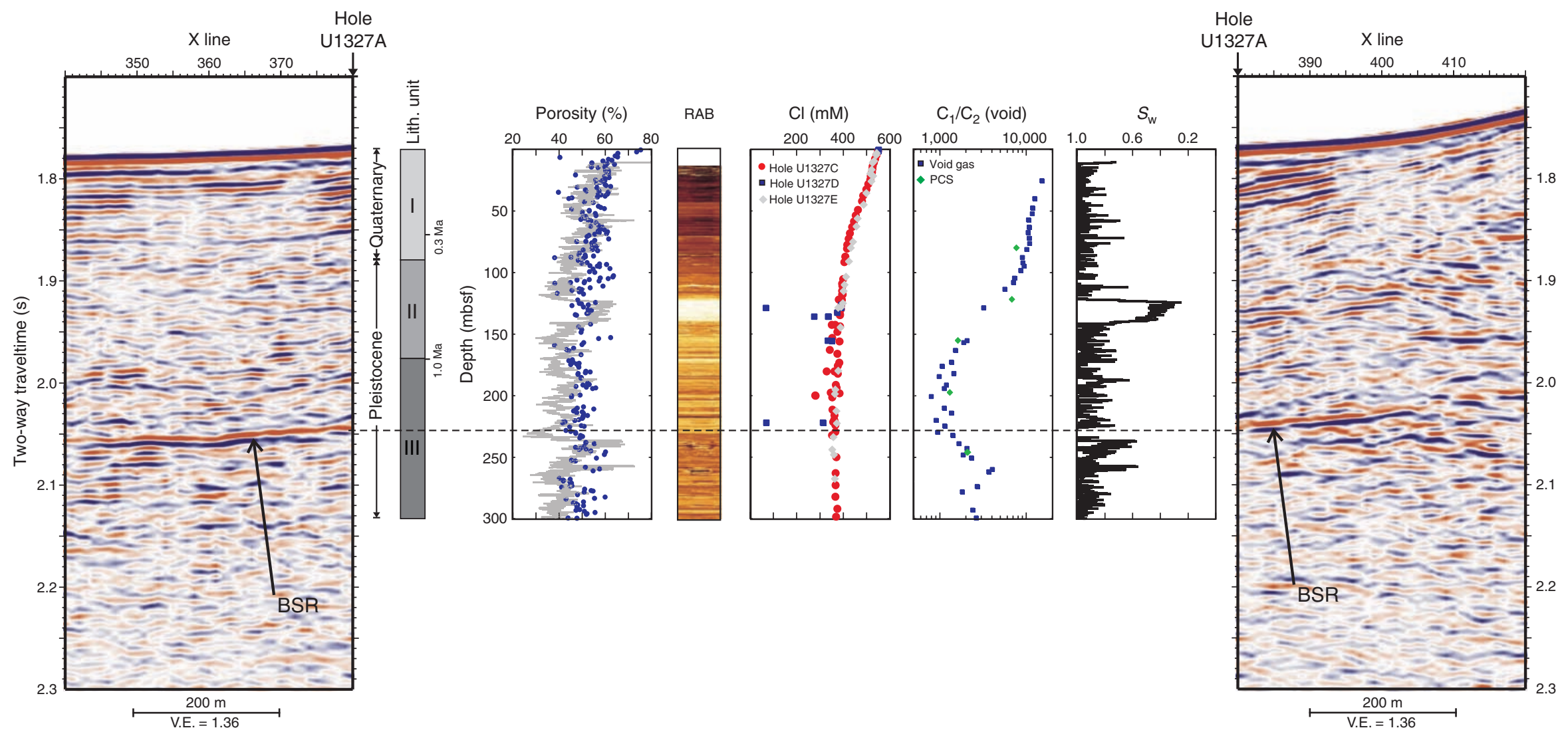



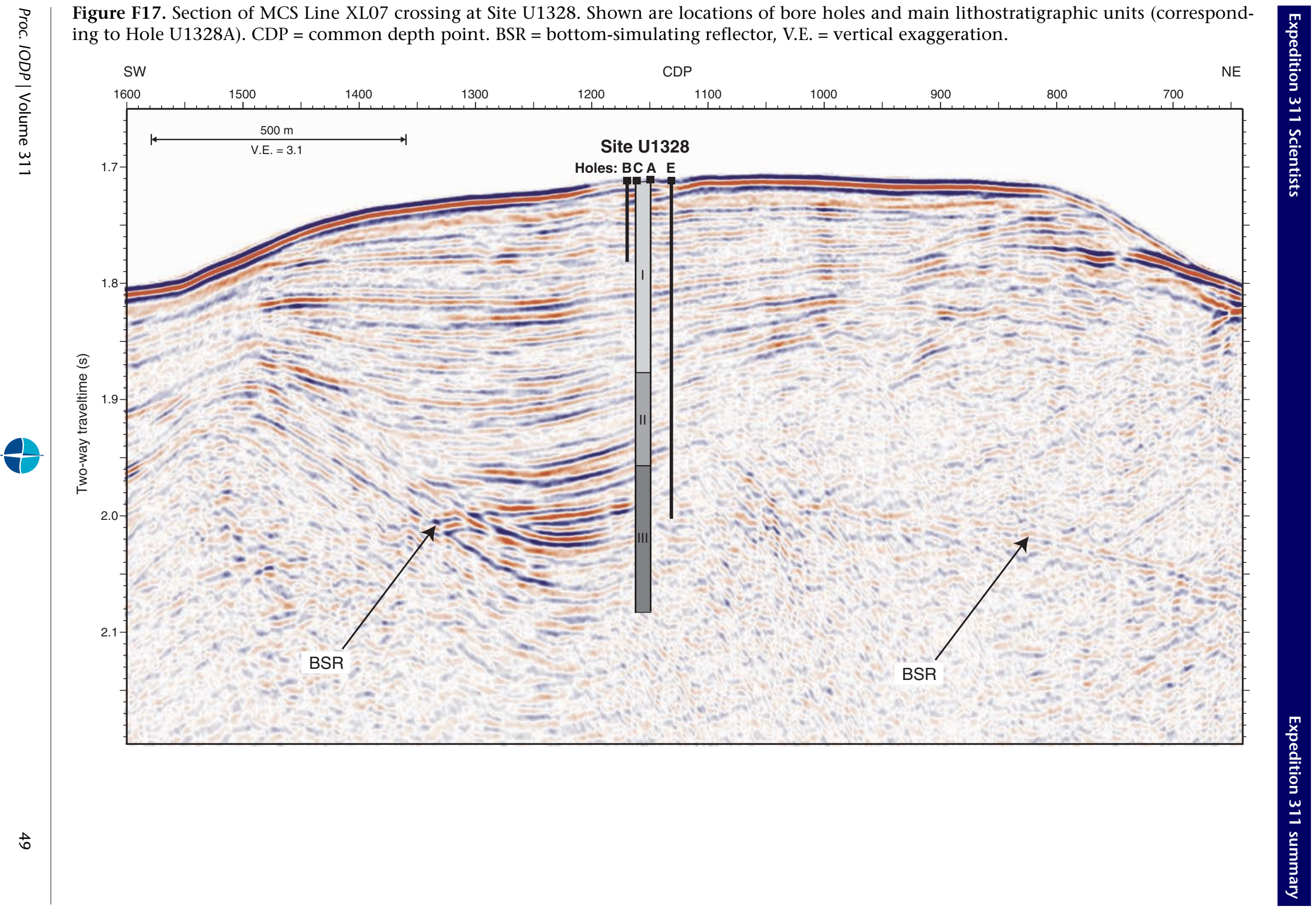
Figure F18. Comparison of major downhole measurements with seismic section from Line XL07 crossing at Hole U1328A. Shown are lithostratigraphic units and age determination, porosity from LWD and MAD analyses, resistivity-at-the-bit (RAB) image of LWD resistivity, pore water chlorinity, $\mathrm{C}_{1} / \mathrm{C}_{2}$ ratio of the void gas, and pore water saturation $\left(S_{\mathrm{w}}\right)$ derived from LWD data using Archie's law. Solid triangle $=$ seawater Cl. BSR = bottom-simulating reflector, $\mathrm{CDP}=$ common depth point, $\mathrm{PCS}=$ pressure core sampler, V.E. = vertical exaggeration.
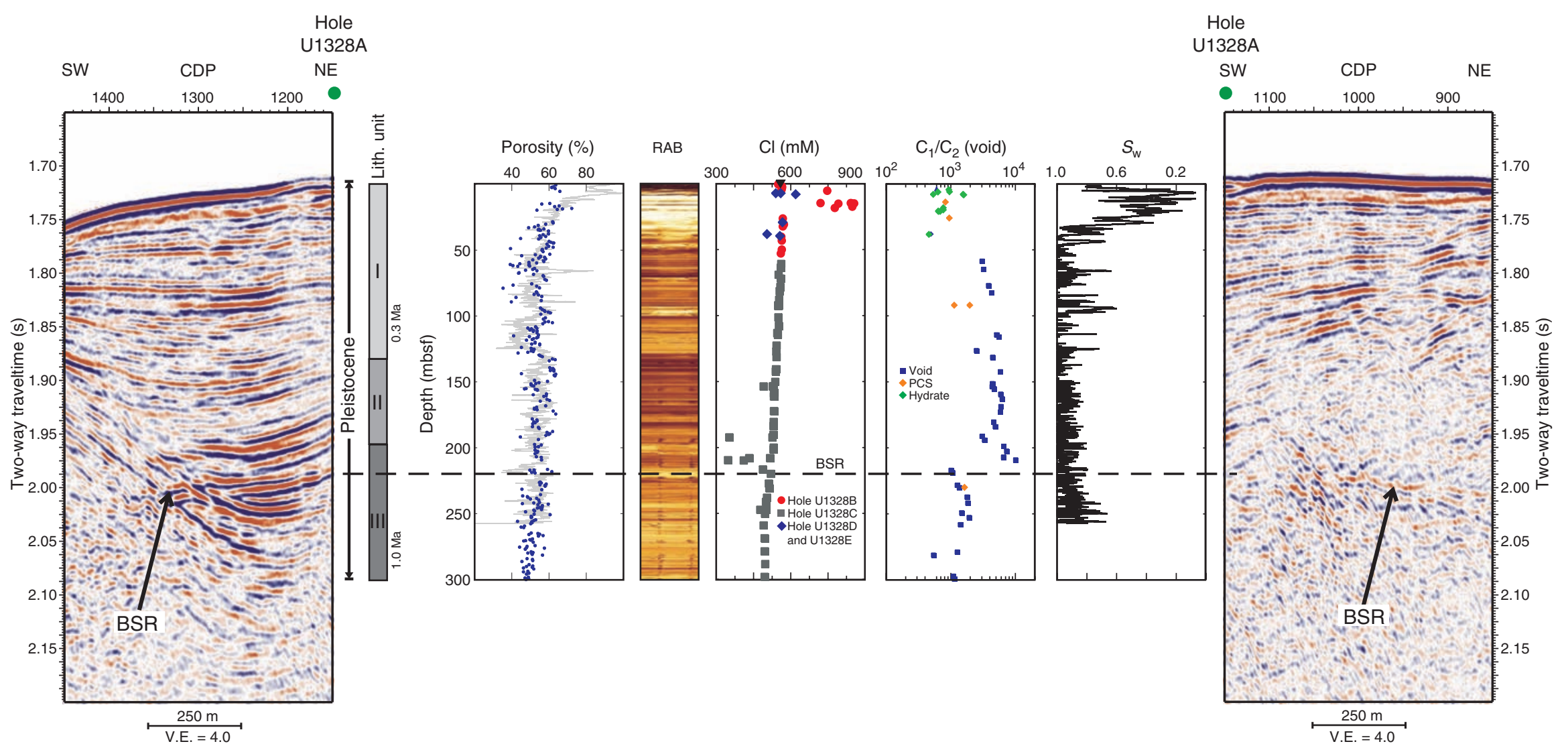
Figure F19. Comparison of major downhole measurements with seismic section from Inline 27 of the 1999 MCS pseudo-3-D data set crossing at Hole U1328A. Shown are lithostratigraphic units and age determination, porosity from LWD and MAD analyses, resistivity-at-the-bit (RAB)


law. Solid triangle $=$ seawater $\mathrm{Cl}, \mathrm{BSR}=$ bottom-simulating reflector, $\mathrm{PCS}=$ pressure core sampler, V.E. $=$ vertical exaggeration .

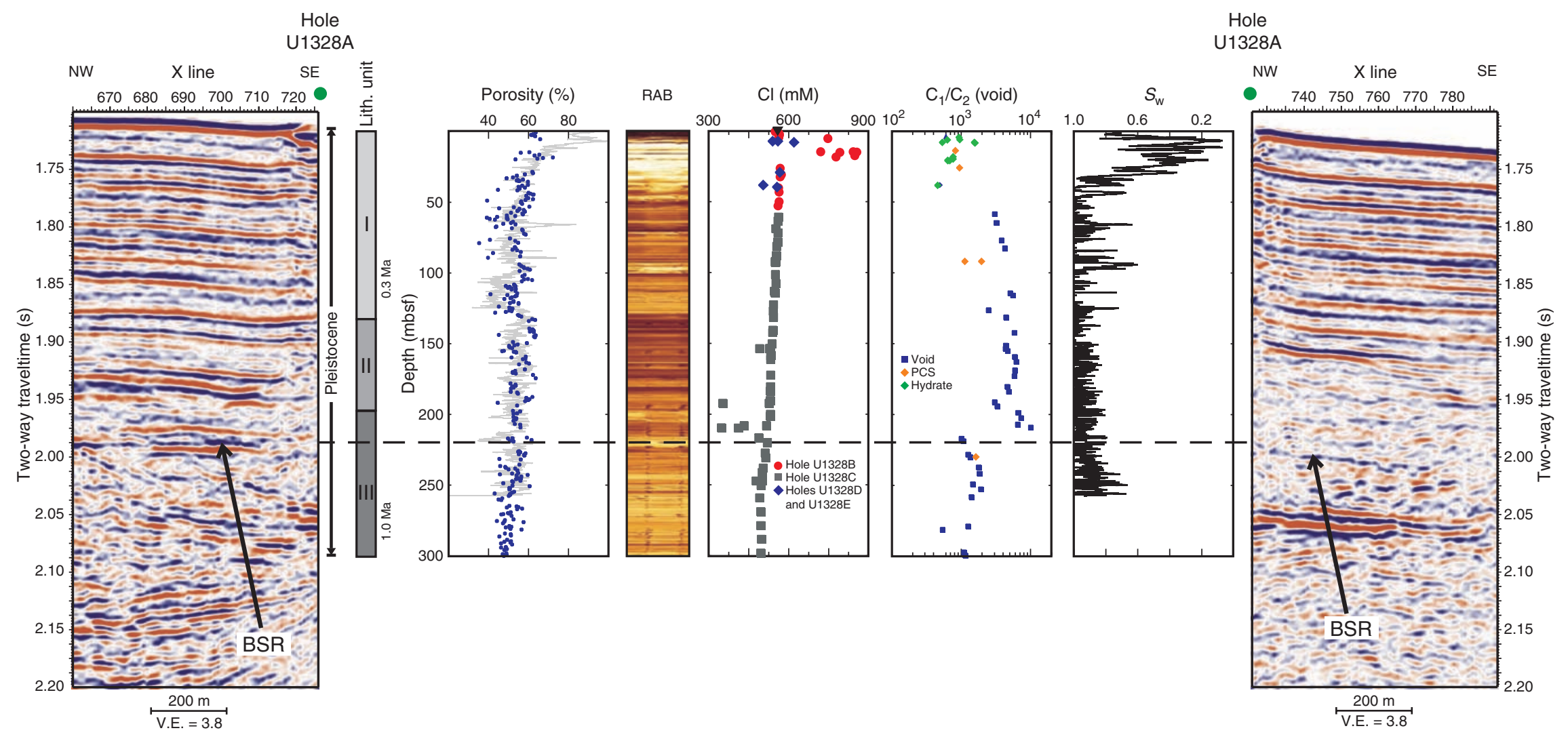


Figure F20. Seismic section from MCS Line 89-08 with overlay of lithostratigraphic units. The base of Unit I may be correlated to a shallow reflector that can be traced across the entire section shown. The boundary between Units II and III is an unconformity, which can be traced clearly between common depth points (CDPs) 3575 and 3650. V.E. = vertical exaggeration.

SW

CDP

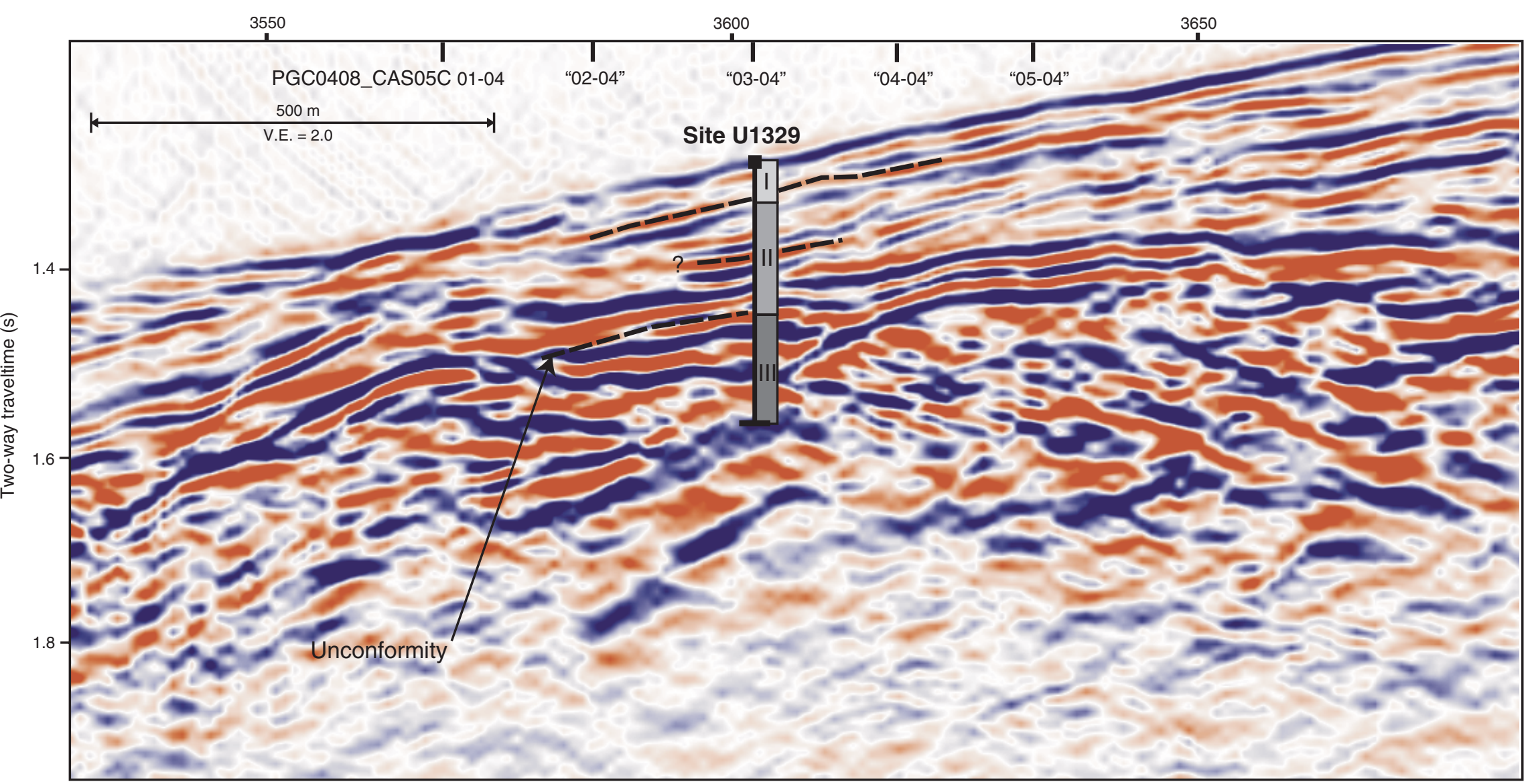


Figure F21. Seismic section from SCS Line CAS05C-01-04 showing some indication of a bottom-simulating reflector (BSR) at $\sim 155$ ms TWT ( 125 mbsf). The boundary between lithostratigraphic Units II and III is $\sim 10 \mathrm{~m}$ deeper than the predicted BSR depth and cannot be clearly identified. $\mathrm{CPD}=$ common depth point, V.E. = vertical exaggeration.

NW

CDP

SE

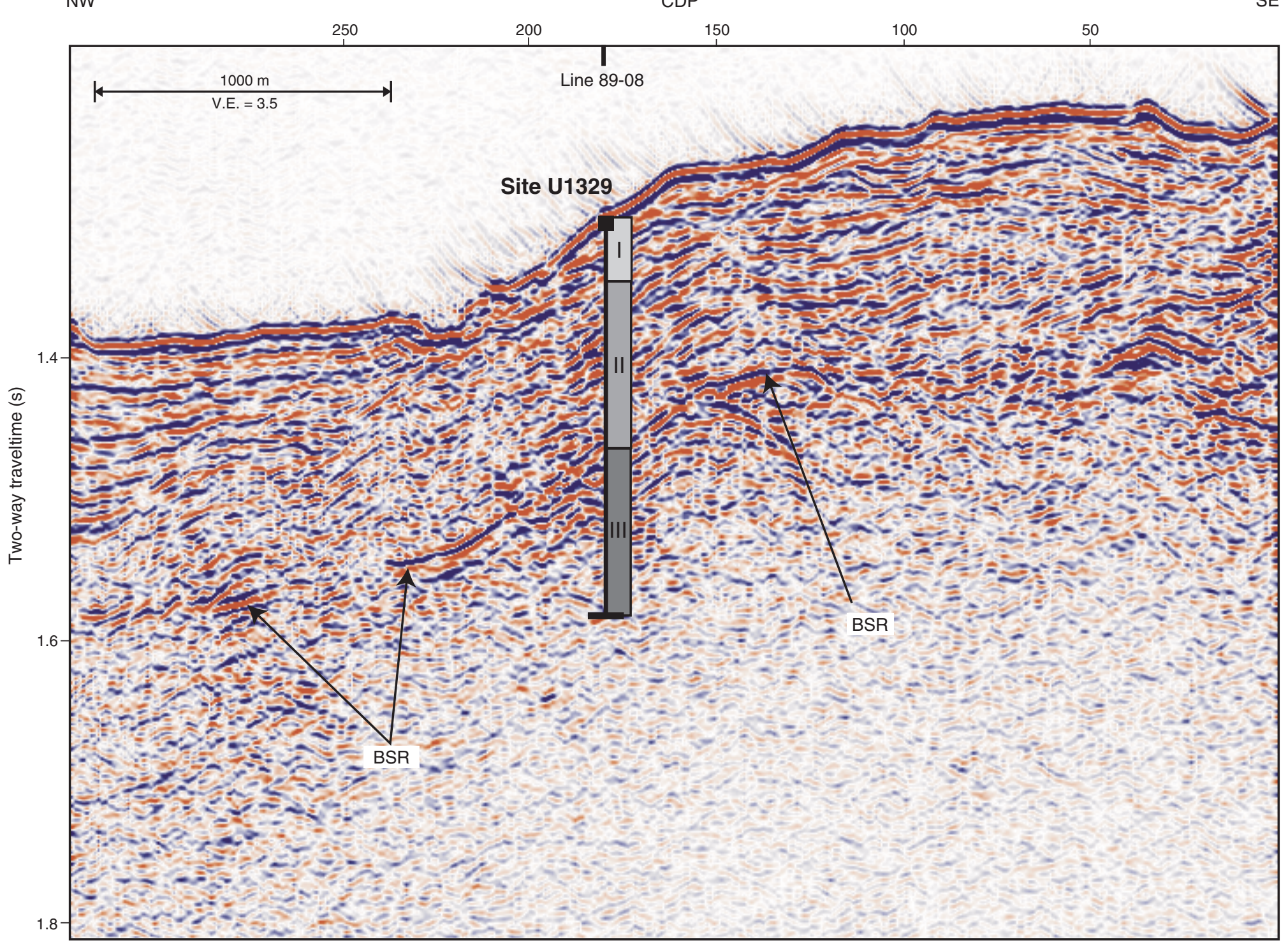


Figure F22. Summary of core and downhole logging data from Site U1329 in comparison to the MCS data from Line 89-08. Shown are lithostratigraphic units and age determination, porosity from logging while drilling (LWD) and moisture and density (MAD) analyses, resistivity-at-the-bit (RAB) image of LWD resistivity, pore water chlorinity, $\mathrm{C}_{1} / \mathrm{C}_{2}$ ratio of the void gas, and pore water saturation $\left(S_{\mathrm{w}}\right)$ derived from LWD data using Archie's law. BSR = bottom-simulating reflector, CDP = common depth point, PCS = pressure core sampler, V.E. = vertical exaggeration .

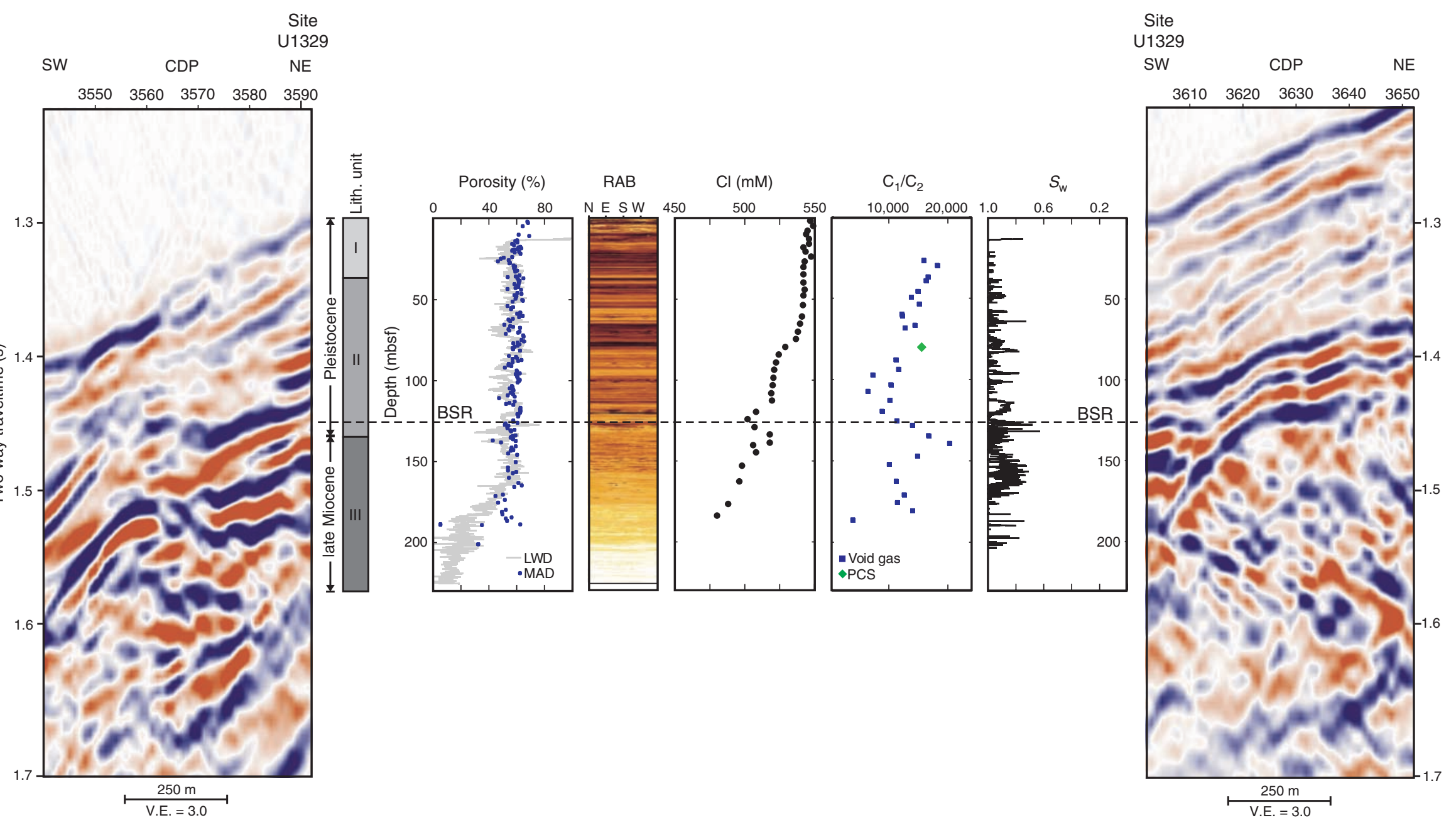


Figure F23. Summary of core and downhole logging data from Site U1329 in comparison to the SCS data from Line CAS05C-01-04. Shown are lithostratigraphic units and age determination, porosity from logging while drilling (LWD) and moisture and density (MAD) analyses, resistivityat-the-bit (RAB) image of LWD resistivity, pore water chlorinity, $\mathrm{C}_{1} / \mathrm{C}_{2}$ ratio of the void gas and pore water saturation $\left(S_{\mathrm{w}}\right)$ derived from LWD data using Archie's law. BSR = bottom-simulating reflector, PCS = pressure core sampler, V.E. = vertical exaggeration.




Figure F24. Images of pore-filling gas hydrate within coarse-grained sands. A-C. Interval 311-U1326C-6X-4, 83-96 cm (44.85 mbsf). D. Interval 311-U1326C-7X-3, 77-85 cm (53.27 mbsf).

A

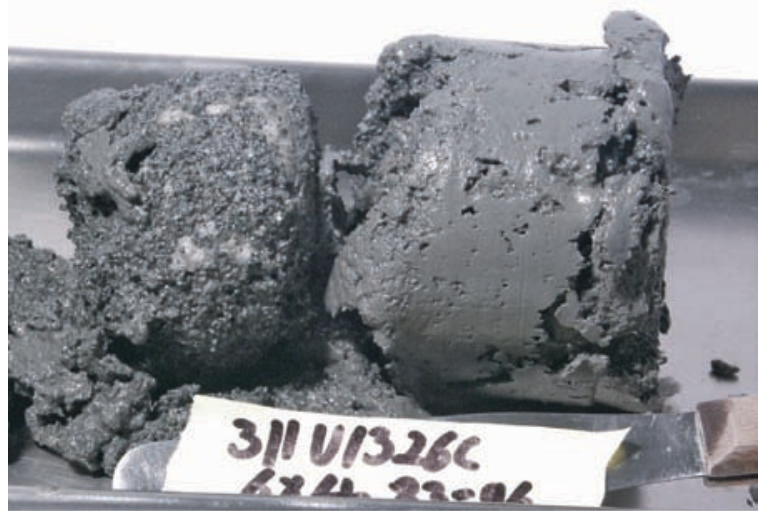

$3 \mathrm{~cm}$

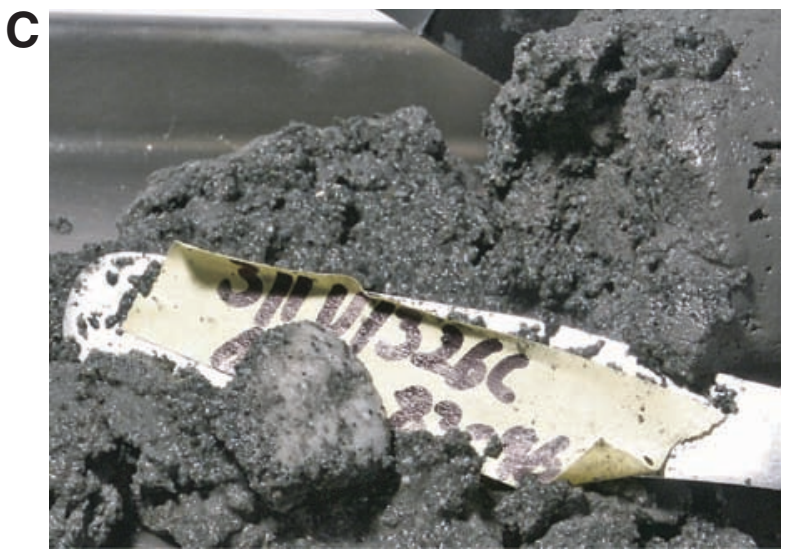

$2 \mathrm{~cm}$

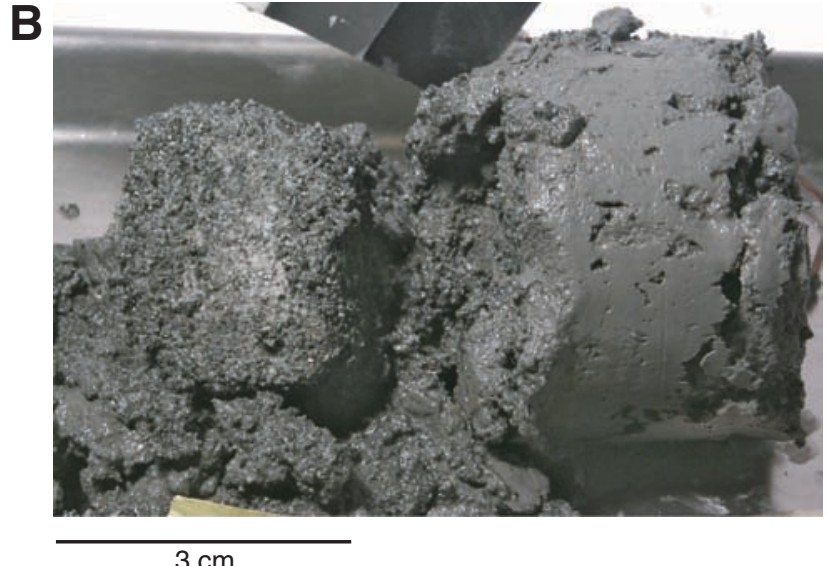

$3 \mathrm{~cm}$

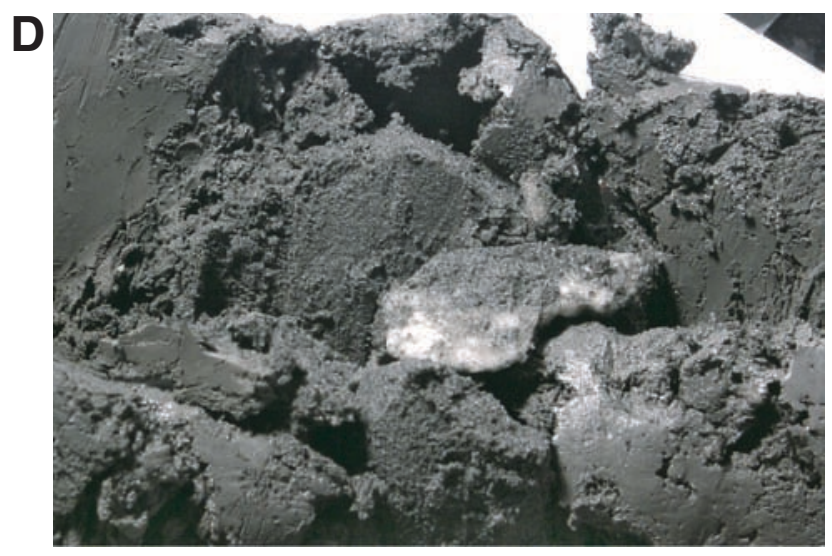

$3 \mathrm{~cm}$ 
Figure F25. Images of gas hydrate samples recovered at cold vent Site U1328. A, B. Interval 311-U1328E-2X-2, 80-90 cm (8.69 mbsf). C. Section 311-U1328E-2X-CC.

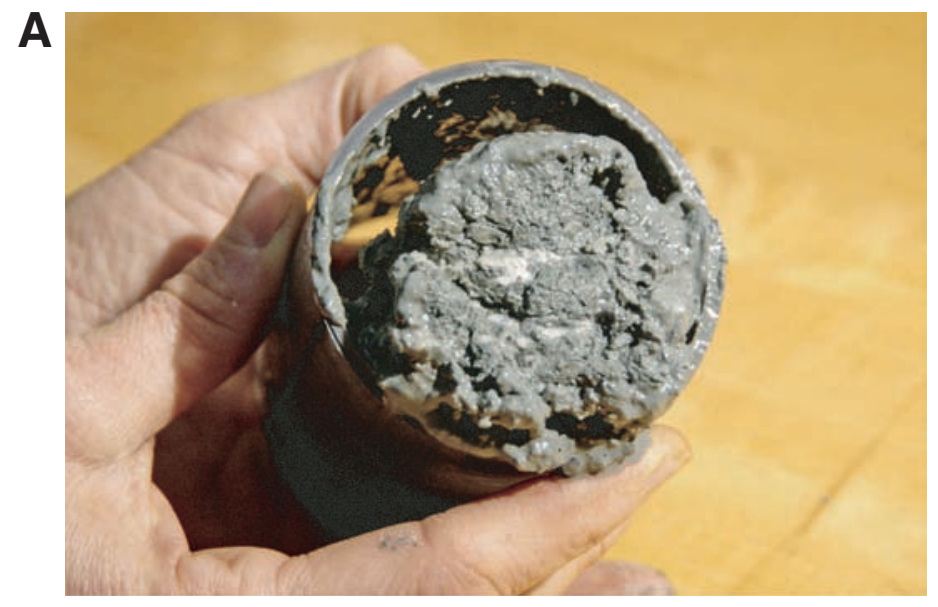

B

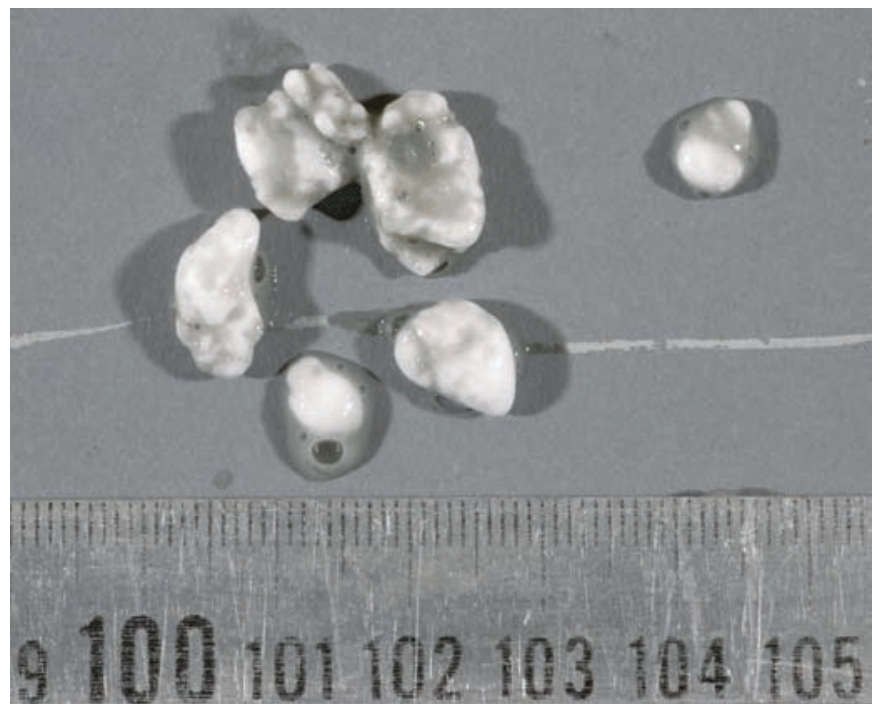

C




Figure F26. A. All reliable in situ temperature measurements obtained during Expedition 311. Data from ODP Leg 146 Site 889 are also included. B. Regional heat flow trend (dashed line; Hyndman and Wang, 1993) compared to heat flow estimated at Sites U1325-U1329 assuming a thermal conductivity value of $1.1 \mathrm{~W} /(\mathrm{m} \cdot \mathrm{K})$. The depth to the base of the gas hydrate stability zone (GHSZ) implied by the temperature measurements is also shown. C. Seismic transect across the margin showing the structural setting of the Expedition 311 sites. $\mathrm{BSR}=$ bottom-simulating reflector.
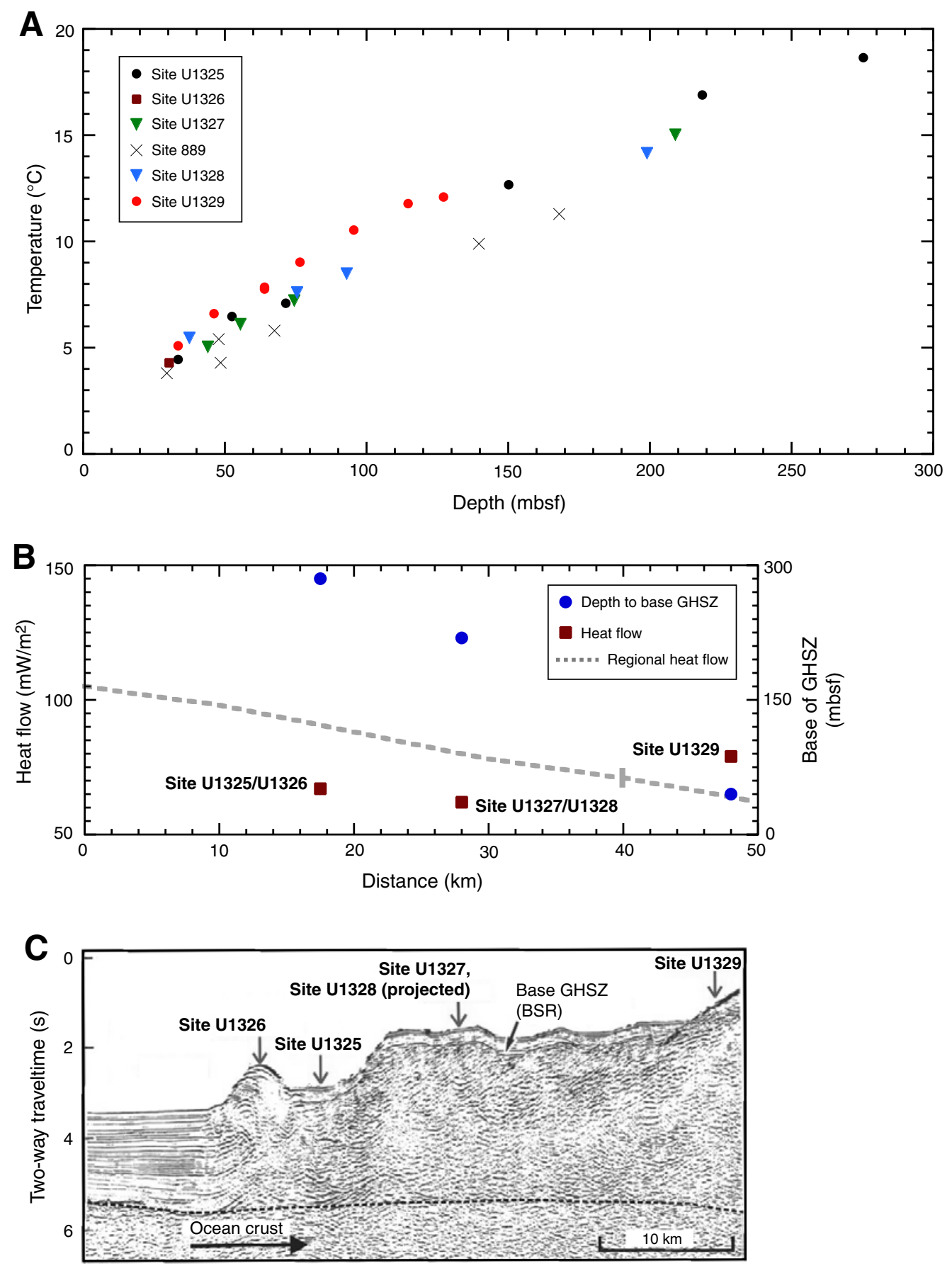
Figure F27. Summary of Expedition 311 interstitial water chlorinity profiles, including average interstitial water $\mathrm{Cl}$ from pressure core sampler (PCS) core. Sites 889/890 data are shown for comparison. Also shown are lithostratigraphic units, LWD RAB resistivity images, and location of the bottom-simulating reflector (BSR). Solid triangle = seawater $\mathrm{Cl}$.

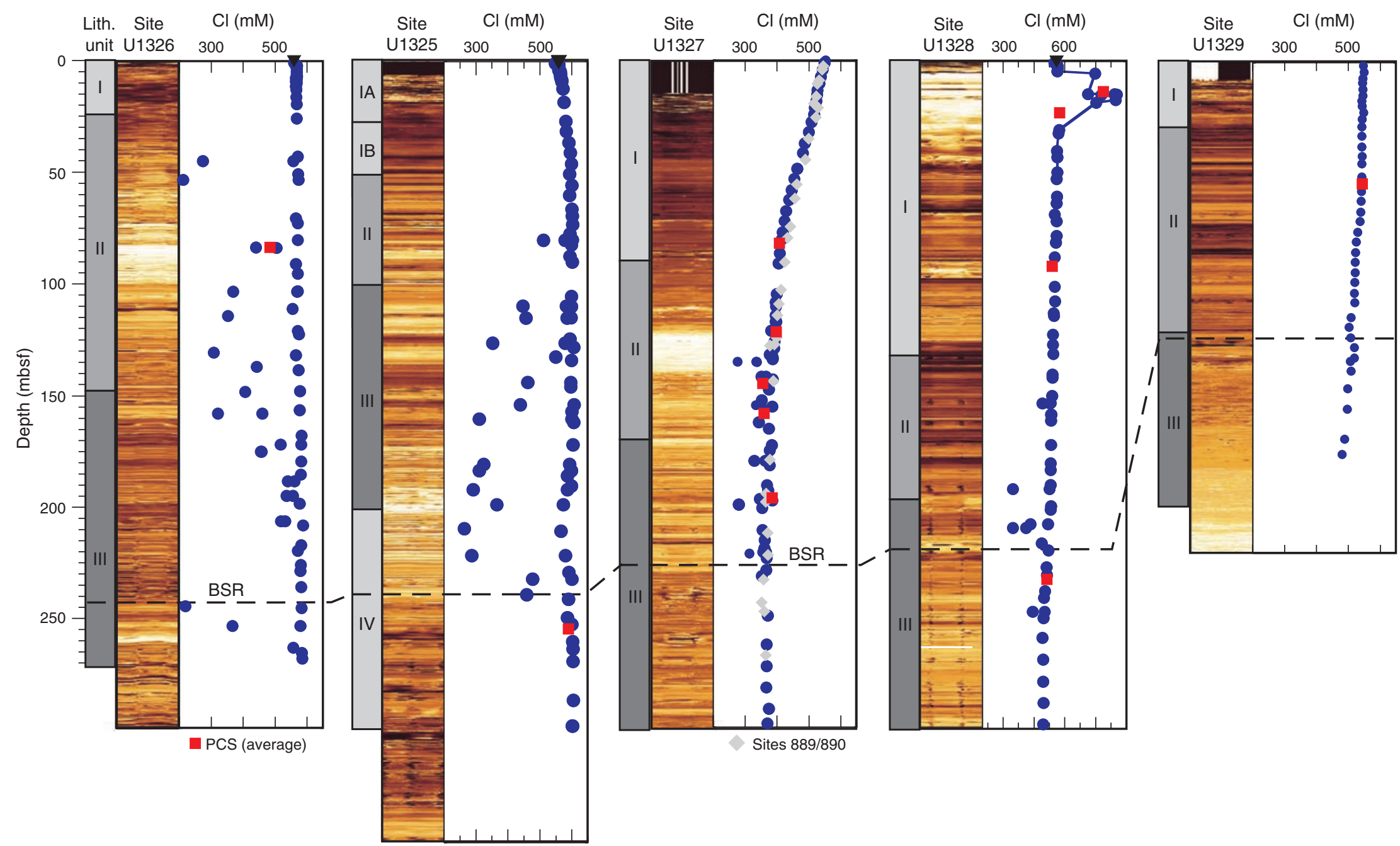



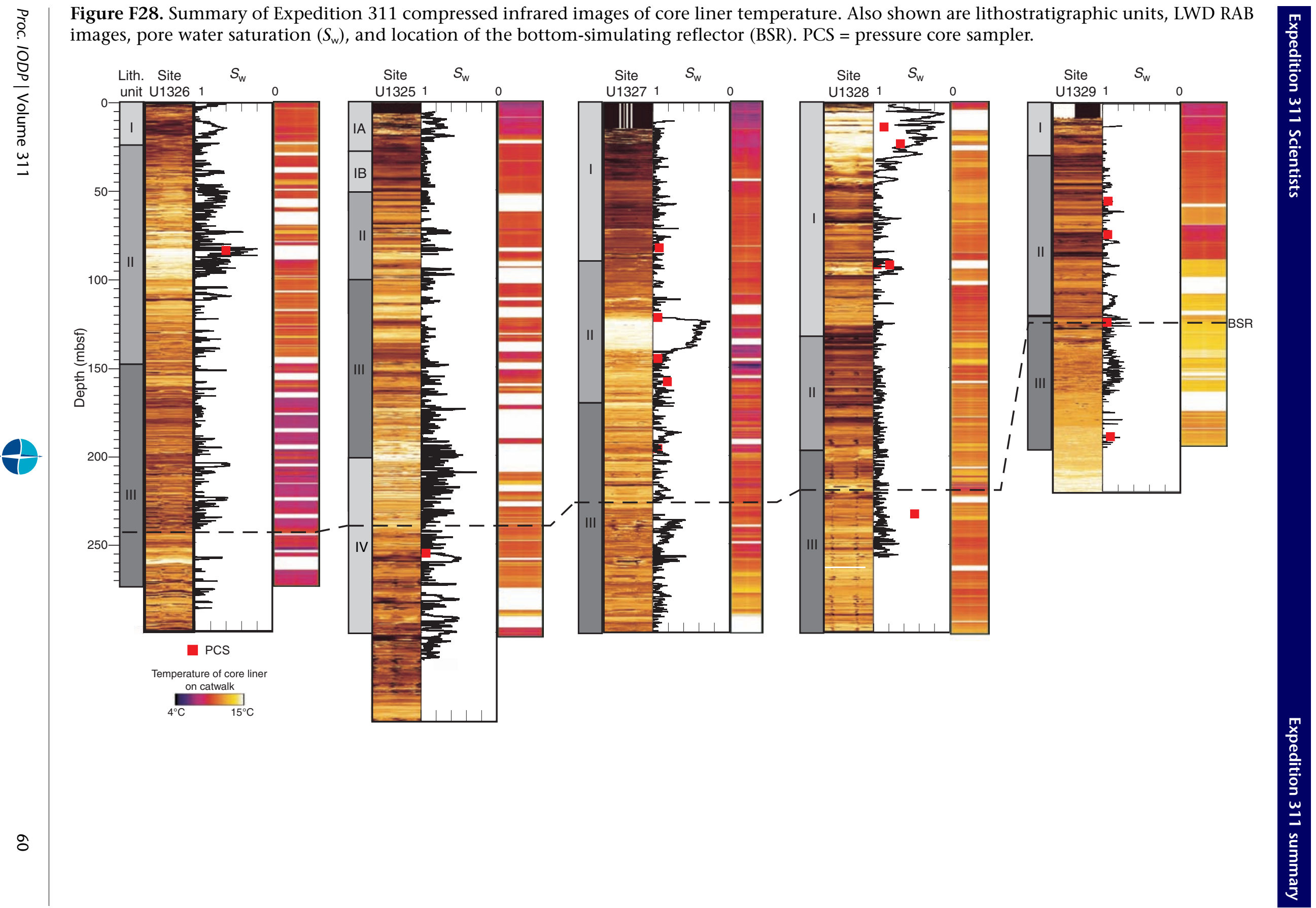


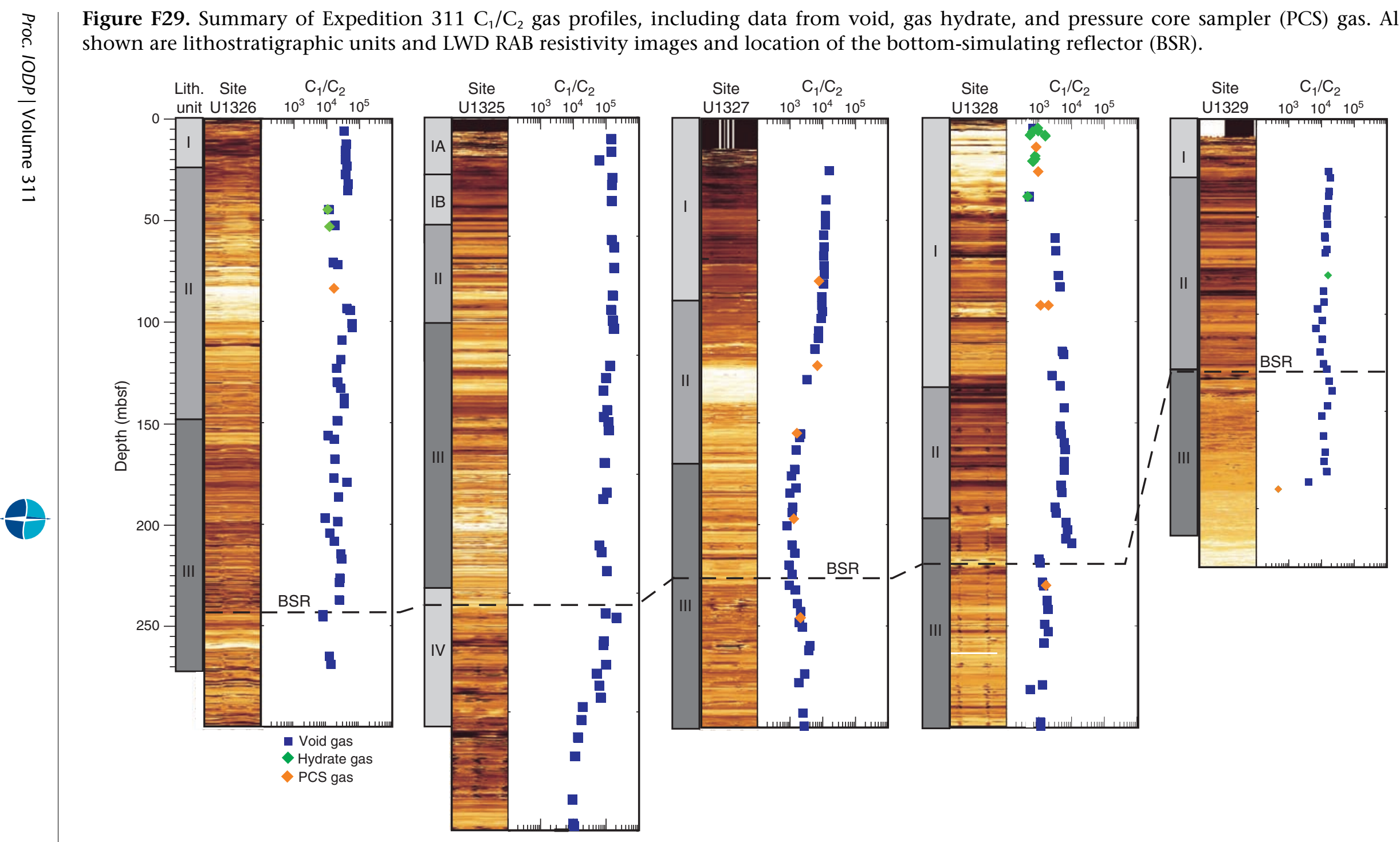


Figure F30. Summary of Expedition 311 pore water saturations derived from LWD data using Archie's relation and from pressure core sampler (PCS) degassing experiments. Also shown are lithostratigraphic units and LWD RAB resistivity images and location of the bottom-simulating reflector (BSR). $S_{\mathrm{h}}=$ gas hydrate saturation.

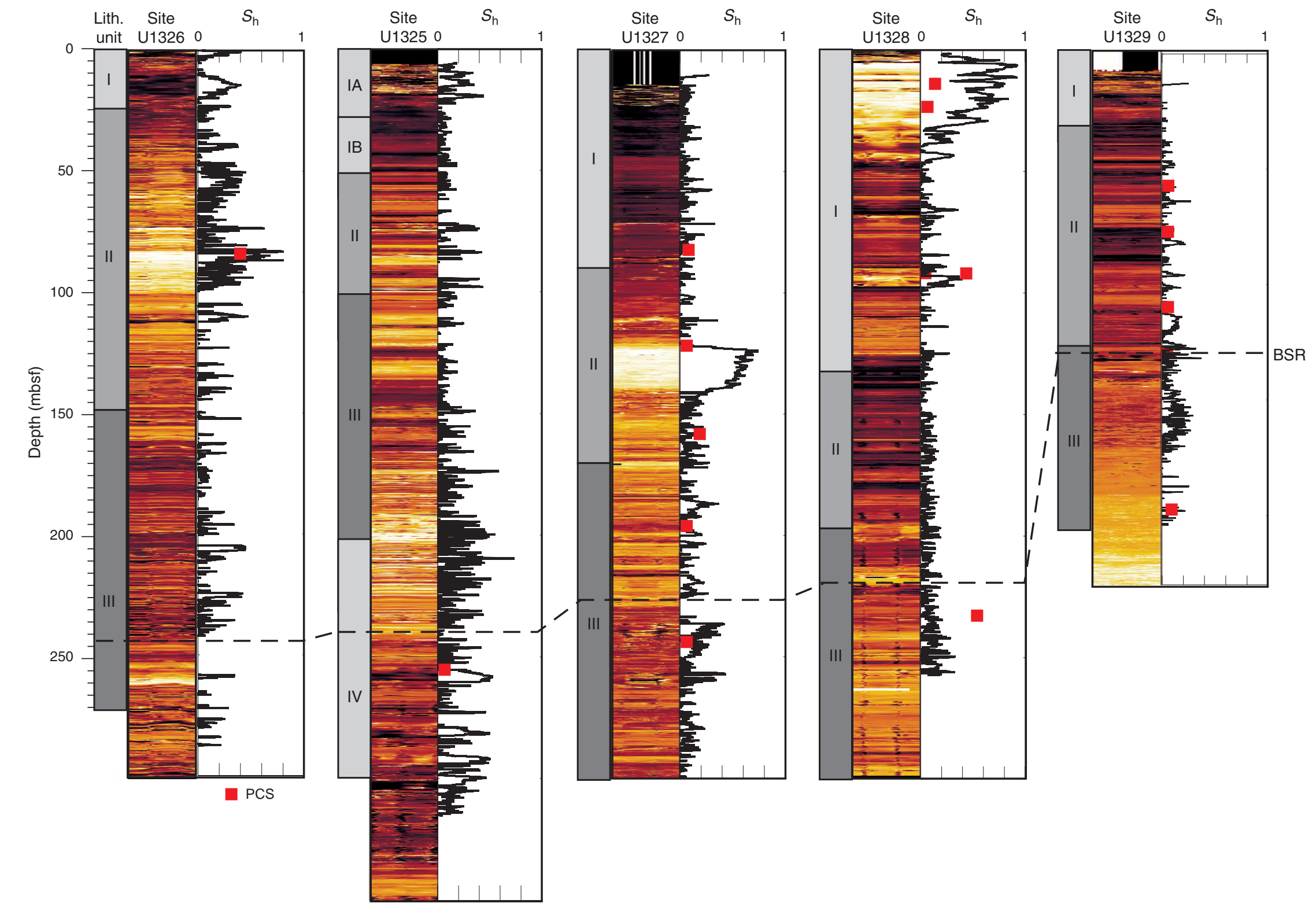






igure F31. Methane phase diagram for Expedition 311 sites, with total methane concentration measured from depressurized PCS cores. The sea-

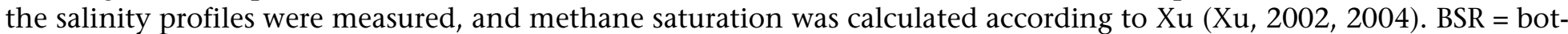
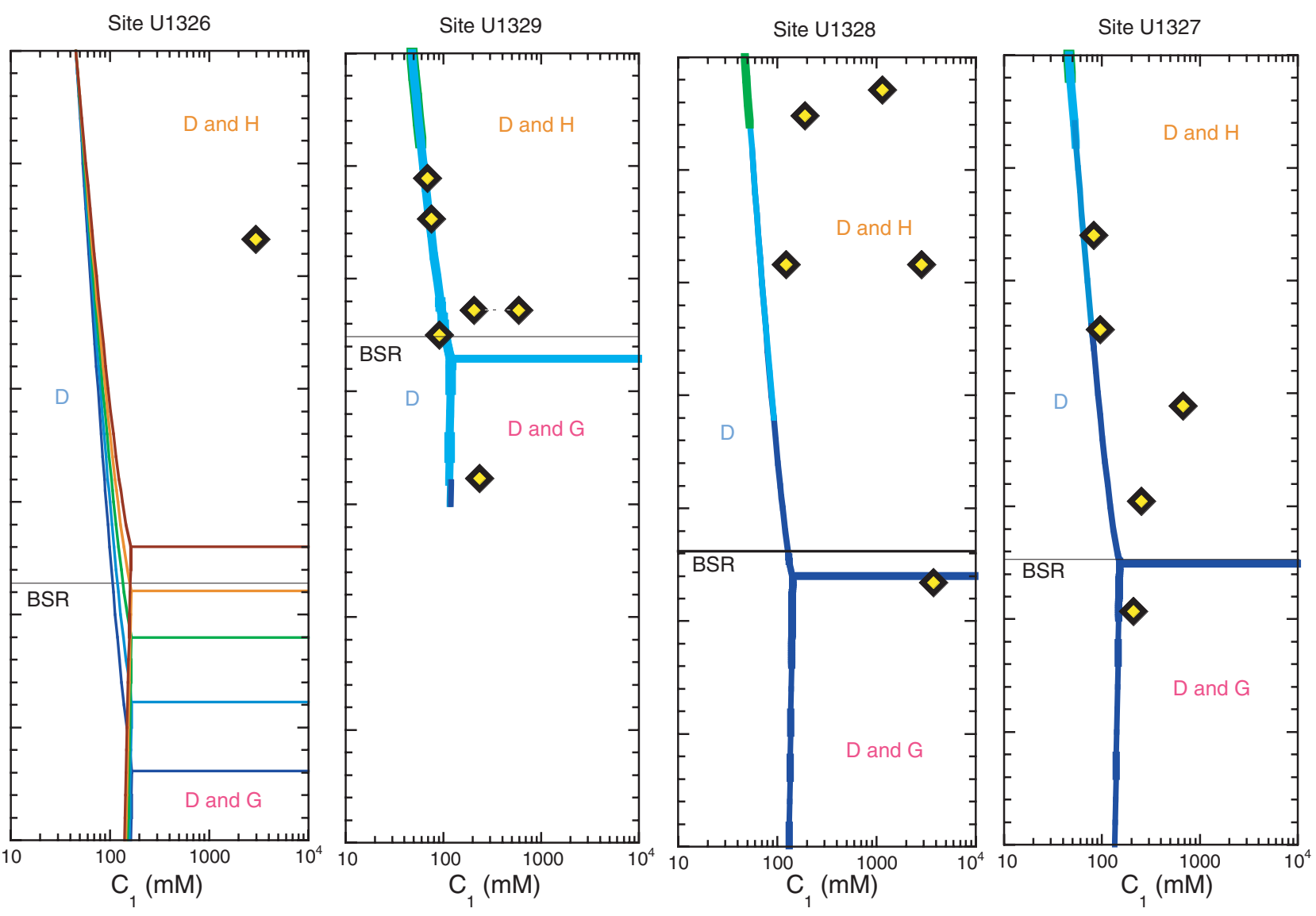


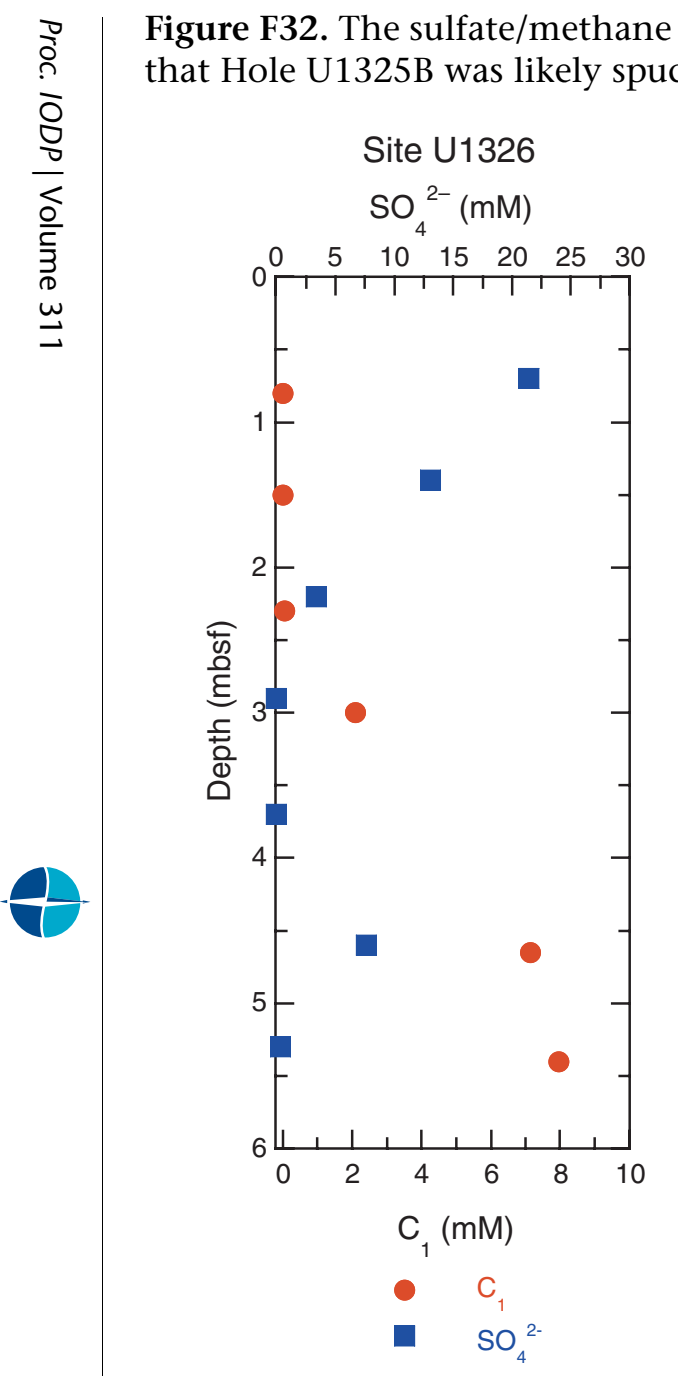

Figure F32. The sulfate/methane interface at Expedition 311 sites. Note the offset at Site U1325, where the mudline core at Hole U1325D showed that Hole U1325B was likely spudded at $\sim 3$ mbsf.


- C: Hole U1325D

- C $_{1}$ : Hole U1325E

- C: Hole U1327D

- $\mathrm{SO}_{4}^{2 \cdot}:$ Hole U1325D

$\square \quad \mathrm{SO}_{4}^{2 \cdot}:$ Hole U1325E

C $\quad$ : Hole U1327E

- $\mathrm{SO}_{4}^{2 \cdot}:$ Hole U1327D

$\square \quad \mathrm{SO}_{4}^{2-:}$ Hole U1327E

- $\quad C_{1}$ : Hole U1328B

- $C_{1}^{1}$ : Hole U1328D

- $\quad C_{4}$ : Hole 1329E

- $\mathrm{SO}_{4}{ }^{2-}$ ! Hole U1328B

- $\mathrm{SO}_{4}^{2-:}$ Hole $1329 \mathrm{E}$ 
Table T1. Expedition 311 operations summary.

\begin{tabular}{|c|c|c|c|c|c|c|c|c|c|}
\hline Hole & Latitude & Longitude & $\begin{array}{l}\text { Water depth } \\
(\text { (mbsl) }\end{array}$ & $\begin{array}{l}\text { Cores } \\
(N)\end{array}$ & $\begin{array}{l}\text { Cored } \\
(\mathrm{m})\end{array}$ & $\begin{array}{l}\text { Recovered } \\
(\mathrm{m})\end{array}$ & $\begin{array}{c}\text { Recovery } \\
\text { (\%) }\end{array}$ & $\begin{array}{l}\text { Drilled } \\
(\mathrm{m})\end{array}$ & $\begin{array}{l}\text { Penetration } \\
\text { (m) }\end{array}$ \\
\hline U1325A & $48^{\circ} 38.691^{\prime} \mathrm{N}$ & $126^{\circ} 58.991^{\prime} \mathrm{W}$ & 2201.1 & 0 & 0 & 0.00 & & 350.0 & 350.0 \\
\hline U1325B & $48^{\circ} 38.694^{\prime} \mathrm{N}$ & $126^{\circ} 58.999^{\prime} \mathrm{W}$ & 2194.8 & 28 & 205.5 & 141.17 & 68.7 & 1.0 & 206.5 \\
\hline U1325C & $48^{\circ} 38.701^{\prime} \mathrm{N}$ & $126^{\circ} 59.007^{\prime} \mathrm{W}$ & 2194.8 & 15 & 115.5 & 62.49 & 54.1 & 188.8 & 304.3 \\
\hline \multirow[t]{2}{*}{ U1325D } & $48^{\circ} 38.701^{\prime} \mathrm{N}$ & $126^{\circ} 59.007^{\prime} \mathrm{W}$ & 2194.6 & 1 & 4.7 & 4.69 & 99.8 & 0.0 & 4.7 \\
\hline & & \multicolumn{2}{|c|}{ Site U1325 totals: } & 44 & 325.7 & 208.35 & 64.0 & 539.8 & 865.5 \\
\hline U1326A & $48^{\circ} 37.635^{\prime} \mathrm{N}$ & $127^{\circ} 3.029^{\prime} \mathrm{W}$ & 1828.1 & 0 & 0 & 0.00 & & 300.0 & 300.0 \\
\hline U1326B & $48^{\circ} 37.638^{\prime} \mathrm{N}$ & $127^{\circ} 3.023^{\prime} \mathrm{W}$ & 1828.4 & 1 & 1.5 & 1.55 & 103.3 & 0.0 & 1.5 \\
\hline U1326C & $48^{\circ} 37.638^{\prime} \mathrm{N}$ & $127^{\circ} 3.023^{\prime} \mathrm{W}$ & 1828.0 & 13 & 85.7 & 54.39 & 63.0 & 1.0 & 86.7 \\
\hline \multirow[t]{2}{*}{ U1326D } & $48^{\circ} 37.628^{\prime} \mathrm{N}$ & $127^{\circ} 3.043^{\prime} \mathrm{W}$ & 1827.9 & 20 & 192.6 & 121.96 & 63.3 & 107.4 & 300.0 \\
\hline & & \multicolumn{2}{|c|}{ Site U1326 totals: } & 34 & 279.8 & 177.9 & 229.6 & 408.4 & 688.2 \\
\hline U1327A & $48^{\circ} 41.887^{\prime} \mathrm{N}$ & $126^{\circ} 51.921^{\prime} \mathrm{W}$ & 1322.1 & 0 & 0 & 0.00 & & 300.0 & 300.0 \\
\hline U1327B & $48^{\circ} 41.889^{\prime} \mathrm{N}$ & $126^{\circ} 51.914^{\prime} \mathrm{W}$ & 1306.1 & 1 & 9.5 & 9.79 & 103.1 & 0.0 & 9.5 \\
\hline U1327C & $48^{\circ} 41.889^{\prime} \mathrm{N}$ & $126^{\circ} 51.914^{\prime} \mathrm{W}$ & 1304.5 & 35 & 297 & 262.17 & 88.3 & 3.0 & 300.0 \\
\hline U1327D & $48^{\circ} 41.895^{\prime} \mathrm{N}$ & $126^{\circ} 51.906^{\prime} \mathrm{W}$ & 1303.7 & 17 & 75.9 & 53.99 & 71.1 & 224.1 & 300.0 \\
\hline \multirow[t]{2}{*}{ U1327E } & $48^{\circ} 41.900^{\prime} \mathrm{N}$ & $126^{\circ} 51.896^{\prime} \mathrm{W}$ & 1303.4 & 4 & 12.5 & 12.37 & 99.0 & 287.5 & 300.0 \\
\hline & & \multicolumn{2}{|c|}{ Site U1327 totals: } & 57 & 394.9 & 338.32 & 85.7 & 814.6 & 1209.5 \\
\hline U1328A & $48^{\circ} 40.072^{\prime} \mathrm{N}$ & $126^{\circ} 51.022^{\prime} \mathrm{W}$ & 1268.1 & 0 & 0 & 0.00 & & 300.0 & 300.0 \\
\hline U1328B & $48^{\circ} 40.048^{\prime} \mathrm{N}$ & $126^{\circ} 51.056^{\prime} \mathrm{W}$ & 1267.8 & 10 & 54.5 & 39.65 & 72.8 & 2.0 & 56.5 \\
\hline U1328C & $48^{\circ} 40.057^{\prime} \mathrm{N}$ & $126^{\circ} 51.044^{\prime} \mathrm{W}$ & 1267.7 & 27 & 242.5 & 195.64 & 80.7 & 57.5 & 300.0 \\
\hline U1328D & $48^{\circ} 40.067^{\prime} \mathrm{N}$ & $126^{\circ} 51.020^{\prime} \mathrm{W}$ & 1266.7 & 3 & 15 & 10.03 & 66.9 & 0.0 & 15.0 \\
\hline \multirow[t]{2}{*}{ U1328E } & $48^{\circ} 40.080^{\prime} \mathrm{N}$ & $126^{\circ} 50.987^{\prime} \mathrm{W}$ & 1264.7 & 13 & 49 & 13.33 & 27.2 & 186.0 & 235.0 \\
\hline & & \multicolumn{2}{|c|}{ Site U1328 totals: } & 53 & 361 & 258.65 & 71.6 & 545.5 & 906.5 \\
\hline U1329A & $48^{\circ} 47.369^{\prime} \mathrm{N}$ & $126^{\circ} 40.713^{\prime} \mathrm{W}$ & 959.1 & 0 & 0 & 0.00 & & 220.0 & 220.0 \\
\hline U1329B & $48^{\circ} 47.375^{\prime} \mathrm{N}$ & $126^{\circ} 40.720^{\prime} \mathrm{W}$ & 953.0 & 1 & 9.5 & 10.02 & 105.5 & 0.0 & 9.5 \\
\hline U1329C & $48^{\circ} 47.375^{\prime} \mathrm{N}$ & $126^{\circ} 40.720^{\prime} \mathrm{W}$ & 946.4 & 23 & 187.5 & 186.16 & 99.3 & 2.0 & 189.5 \\
\hline U1329D & $48^{\circ} 47.362^{\prime} \mathrm{N}$ & $126^{\circ} 40.716^{\prime} \mathrm{W}$ & 946.4 & 1 & 9.5 & 1.03 & 10.8 & 201.0 & 210.5 \\
\hline \multirow[t]{3}{*}{ U1329E } & $48^{\circ} 47.385^{\prime} \mathrm{N}$ & $126^{\circ} 40.716^{\prime} \mathrm{W}$ & 945.5 & 10 & 48 & 37.74 & 78.6 & 79.0 & 127.0 \\
\hline & & \multicolumn{2}{|c|}{ Site U1329 totals: } & 35 & 254.5 & 234.95 & 92.3 & 502.0 & 756.5 \\
\hline & & \multicolumn{2}{|c|}{ Expedition 311 totals: } & 223 & 1615.9 & 1218.17 & 75.4 & 2810.3 & 4426.2 \\
\hline
\end{tabular}


Table T2. Temperature tool deployments.

\begin{tabular}{|c|c|c|c|c|c|c|c|}
\hline Core & $\begin{array}{l}\text { Depth } \\
\text { (mbsf) }\end{array}$ & $\begin{array}{l}\text { Corrected } \\
\text { temperature } \\
\left({ }^{\circ} \mathrm{C}\right)\end{array}$ & $\begin{array}{l}\text { Uncorrected } \\
\text { temperature } \\
\left({ }^{\circ} \mathrm{C}\right)\end{array}$ & $\begin{array}{l}\text { Thermal } \\
\text { conductivity } \\
(\mathrm{W} /[\mathrm{m} \cdot \mathrm{K}])\end{array}$ & $\begin{array}{l}\text { Calibration } \\
\text { correction } \\
\left({ }^{\circ} \mathrm{C}\right)\end{array}$ & $\begin{array}{l}\text { Temperature } \\
\text { tool }\end{array}$ & $\begin{array}{l}\text { Solution } \\
\text { reliability }\end{array}$ \\
\hline \multicolumn{8}{|l|}{ 311-U1325B- } \\
\hline $4 \mathrm{H}$ & 33.5 & 4.44 & 4.44 & 1.1 & 0 & APCT-3 & Excellent \\
\hline $6 \mathrm{H}$ & 52.5 & 6.47 & 6.47 & 1.1 & 0 & APCT-3 & Excellent \\
\hline $8 \mathrm{H}$ & 71.5 & 7.11 & 7.11 & 1.1 & 0 & APCT-3 & Excellent \\
\hline $19 X-20 X$ & 150.2 & 12.66 & 12.66 & 1.1 & 0 & DVTP & Excellent \\
\hline \multicolumn{8}{|c|}{ 311-U1325C- } \\
\hline $5 \mathrm{H}-6 \mathrm{H}$ & 218.6 & 16.89 & 16.89 & 1.1 & 0 & DVTP & Good \\
\hline $12 \mathrm{H}-13 \mathrm{H}$ & 275.4 & 18.64 & 18.64 & 1.1 & 0 & DVTP & Very good \\
\hline \multicolumn{8}{|c|}{ 311-U1326C- } \\
\hline $4 \mathrm{H}$ & 30.4 & 4.3 & 4.3 & 1.1 & 0 & APCT-3 & Very good \\
\hline \multicolumn{8}{|c|}{ 311-U1326D- } \\
\hline $19 X$ & 252.2 & $\mathrm{NA}^{\dagger}$ & NA & 1.1 & 0 & DVTP & Poor (heave) \\
\hline $21 x$ & 271.4 & NA & NA & 1.1 & 0 & DVTP & Fair (heave) \\
\hline $\mathrm{BOH}$ & 300.0 & NA & NA & 1.1 & 0 & DVTP & Fair (heave) \\
\hline \multicolumn{8}{|c|}{ 311-U1327C- } \\
\hline $3 \mathrm{H}$ & 25.1 & NA & NA & NA & -0.97 & APCT16 & Poor \\
\hline $5 \mathrm{H}$ & 44.1 & 6.6 & 7.6 & 1.1 & -0.97 & AРCT16 & Good \\
\hline $7 \mathrm{H}$ & 55.6 & 9.04 & 9.005 & 1.1 & -0.97 & APCT16 & Good \\
\hline $9 \mathrm{H}$ & 74.6 & 10.544 & 11.514 & 1.1 & -0.97 & APCT16 & Excellent \\
\hline $19 X-20 X$ & 161.0 & NA & NA & NA & NA & DVTP & Instrument failed \\
\hline $25 X-26 X$ & 209.0 & 15.1 & 15.1 & 1.1 & 0 & DVTPP3 & Excellent \\
\hline $34 X-35 X$ & 295.0 & NA & NA & NA & NA & DVTPP3 & Poor \\
\hline \multicolumn{8}{|l|}{ 311-U1328B- } \\
\hline $8 \mathrm{H}$ & 37.5 & 5.45 & 6.42 & 1.1 & -0.97 & APCT16 & Good \\
\hline $10 \mathrm{H}$ & 56.5 & $10^{*}$ & 10 & 1.1 & 0 & АРCT-3 & Poor (heave) \\
\hline $10 \mathrm{H}-11 \mathrm{H}$ & 56.5 & ND & ND & ND & ND & DVTPP3 & No data \\
\hline \multicolumn{8}{|c|}{ 311-U1328C- } \\
\hline $2 \mathrm{H}$ & 75.5 & 7.57 & 8.54 & 1.1 & -0.97 & APCT16 & Good \\
\hline $3 \mathrm{H}$ & 85.0 & 9 & 9 & 1.1 & 0 & APCT-3 & Poor \\
\hline $6 \mathrm{H}$ & 103.5 & 11 & 11 & 1.1 & 0 & APCT-3 & Poor (heave) \\
\hline $11 X-12 X$ & 148.9 & ND & ND & ND & ND & DVTPP3 & No data \\
\hline $16 X-17 X$ & 197.1 & ND & ND & ND & ND & DVTPP3 & No data \\
\hline \multicolumn{8}{|l|}{ 311-U1328E- } \\
\hline $10 \mathrm{P}-11 \mathrm{Y}$ & 93.0 & 8.47 & 8.47 & 1.1 & 0 & DVTP & Poor (heave) \\
\hline $11 \mathrm{Y}-12 \mathrm{E}$ & 198.0 & 14.13 & 14.13 & 1.1 & 0 & DVTP & Very good \\
\hline \multicolumn{8}{|c|}{ 311-U1329C- } \\
\hline $3 \mathrm{H}$ & 27.1 & NA & NA & NA & -0.97 & APCT16 & Poor \\
\hline $5 \mathrm{H}$ & 46.1 & 6.6 & 7.6 & 1 & -0.97 & APCT16 & Excellent \\
\hline $9 \mathrm{H}$ & 76.6 & 9.04 & 9.005 & 1 & 0.03 & APCT-3 & Excellent \\
\hline $11 \mathrm{H}$ & 95.6 & 10.544 & 11.514 & 1 & -0.97 & АРCT16 & Excellent \\
\hline $13 \mathrm{H}$ & 114.6 & 11.79 & 11.759 & 1 & 0.03 & APCT-3 & Excellent \\
\hline \multicolumn{8}{|l|}{ 311-U1329E- } \\
\hline $4 \mathrm{H}$ & 33.5 & 5.1 & $5.86 / 6.13$ & 1 & -0.97 & APCT16 & Fair \\
\hline $6 \mathrm{H}$ & 64.0 & 7.76 & 8.69 & 1 & -0.97 & APCT16 & Good \\
\hline $6 \mathrm{H}-7 \mathrm{P}$ & 64.0 & 7.84 & 7.84 & 1 & 0 & DVTP & Good \\
\hline $\mathrm{BOH}$ & 127.1 & 12.1 & 12.1 & NA & 0 & DVTP & Excellent \\
\hline
\end{tabular}

Notes: $\mathrm{NA}=$ not applicable, ND = no data. $\mathrm{BOH}=$ bottom of hole. APCT-3 = third-generation advanced piston corer temperature tool, DVTP = Davis-Villinger Temperature Probe, DVTPP $=$ Davis-Villinger Temperature-Pressure Probe, APCT $=$ advanced piston corer temperature tool, ${ }^{*}=$ measurements severely affected by heave are estimated to nearest degree. $\dagger=$ tool did not stay in the seafloor long enough to obtain in situ temperature using CONEFIT; these data will be modeled postcruise in an attempt to place an upper bound on the in situ temperature. 
Table T3. Expedition 311 pressure coring results.

\begin{tabular}{|c|c|c|c|c|c|c|c|c|}
\hline Core & $\begin{array}{l}\text { Date } \\
(2005)\end{array}$ & $\begin{array}{l}\text { Local time } \\
\text { (h) }\end{array}$ & $\begin{array}{l}\text { Top depth } \\
\text { (mbsf) }\end{array}$ & $\begin{array}{l}\text { Cored } \\
(\mathrm{m})\end{array}$ & $\begin{array}{l}\text { Recovered } \\
(\mathrm{m})\end{array}$ & $\begin{array}{l}\text { Recovery } \\
\text { (\%) }\end{array}$ & $\begin{array}{l}\text { Pressurized } \\
\text { core }\end{array}$ & $\begin{array}{l}\text { Gas hydrate } \\
\text { saturation } \\
\text { (\%) }\end{array}$ \\
\hline \multicolumn{9}{|c|}{ 311-U1325B- } \\
\hline $11 \mathrm{P}$ & 18 Oct & 1315 & 82.4 & 1.0 & 0.88 & 88.0 & $\mathrm{~N}$ & \\
\hline $17 \mathrm{E}$ & 18 Oct & 2145 & 129.9 & 1.0 & 0.00 & 0.0 & $\mathrm{~N}$ & \\
\hline $22 Y$ & 19 Oct & 0725 & 169.4 & 1.0 & 0.17 & 17.0 & $\mathrm{~N}$ & \\
\hline $26 \mathrm{E}$ & 19 Oct & 1345 & 197.4 & 1.0 & 0.28 & 28.0 & $\mathrm{~N}$ & \\
\hline $28 \mathrm{P}$ & 19 Oct & 1925 & 206.1 & 0.4 & 0.00 & 0.0 & $\mathrm{~N}$ & \\
\hline \multicolumn{9}{|c|}{ 311-U1325C- } \\
\hline $5 Y$ & 21 Oct & 0600 & 217.6 & 1 & 0.00 & 0.0 & $\mathrm{~N}$ & \\
\hline $10 P$ & 21 Oct & 1750 & 256.1 & 1 & 0.96 & 96.0 & Y & 0.4 \\
\hline \multicolumn{9}{|c|}{ 311-U1326C- } \\
\hline $11 Y$ & 24 Oct & 0445 & 82.7 & 1 & 0.15 & 15.0 & $\mathrm{Y}$ & \\
\hline $12 \mathrm{P}$ & 24 Oct & 0730 & 83.7 & 1 & 0.26 & 26.0 & $\mathrm{Y}$ & 0.4 \\
\hline $13 \mathrm{E}$ & 24 Oct & 0905 & 85.7 & 1 & 0.00 & 0.0 & $\mathrm{~N}$ & \\
\hline \multicolumn{9}{|c|}{ 311-U1327C- } \\
\hline $6 P$ & 2 Oct & 1435 & 44.1 & 1.0 & 1.00 & 100.0 & $\mathrm{~N}$ & \\
\hline $15 \mathrm{P}$ & 3 Oct & 0020 & 121.8 & 1.0 & 1.00 & 100.0 & $\mathrm{Y}$ & 0.2 \\
\hline $24 \mathrm{P}$ & 3 Oct & 1715 & 197.3 & 1.0 & 1.00 & 100.0 & Y & 1.8 \\
\hline \multicolumn{9}{|c|}{ 311-U1327D- } \\
\hline $3 P$ & 4 Oct & 2320 & 83.0 & 1.0 & 0.00 & 0.0 & $\mathrm{~N}$ & \\
\hline $4 \mathrm{E}$ & 6 Oct & 0050 & 125.3 & 1.0 & 1.10 & 110.0 & $\mathrm{Y}$ & \\
\hline $6 Y$ & 6 Oct & 0340 & 132.0 & 1.0 & 0.84 & 84.0 & $\mathrm{~N}$ & \\
\hline $10 \mathrm{P}$ & 6 Oct & 1040 & 155.1 & 1.0 & 0.92 & 92.0 & $\mathrm{Y}$ & 8.0 \\
\hline $12 \mathrm{E}$ & 6 Oct & 1540 & 170.5 & 1.0 & 1.14 & 114.0 & $\mathrm{Y}$ & \\
\hline $13 Y$ & 6 Oct & 2045 & 203.6 & 1.0 & 0.48 & 48.0 & $Y$ & \\
\hline $14 \mathrm{E}$ & 7 Oct & 0110 & 217.7 & 1.0 & 1.15 & 115.0 & Y & \\
\hline $17 \mathrm{P}$ & 7 Oct & 1030 & 246.0 & 1.0 & 1.00 & 100.0 & Y & 0.9 \\
\hline \multicolumn{9}{|c|}{ 311-U1327E- } \\
\hline $2 \mathrm{P}$ & 9 Oct & 1300 & 40.0 & 1.0 & 1.00 & 100.0 & $\mathrm{~N}$ & \\
\hline $3 P$ & 9 Oct & 1550 & 80.0 & 1.0 & 0.95 & 95.0 & Y & 0.2 \\
\hline $4 \mathrm{E}$ & 9 Oct & 2040 & 128.0 & 1.0 & 0.48 & 48.0 & $\mathrm{~N}$ & \\
\hline \multicolumn{9}{|c|}{ 311-U1328B- } \\
\hline $4 P$ & 11 Oct & 1720 & 14.5 & 1.0 & 0.77 & 77.0 & Y & 15.0 \\
\hline $7 P$ & 11 Oct & 2105 & 26.0 & 1.0 & 0.78 & 78.0 & Y & 2.0 \\
\hline \multicolumn{9}{|c|}{ 311-U1328C- } \\
\hline $5 P$ & 13 Oct & 0510 & 92.0 & 1.0 & 0.96 & 96.0 & Y & 0.7 \\
\hline \multicolumn{9}{|c|}{ 311-U1328D- } \\
\hline $3 Y$ & 15 Oct & 2325 & 14.0 & 1.0 & 0.00 & 0.0 & $\mathrm{~N}$ & \\
\hline \multicolumn{9}{|c|}{ 311-U1328E- } \\
\hline $3 \mathrm{E}$ & 16 Oct & 0350 & 8.5 & 1.0 & 0.00 & 0.0 & $\mathrm{~N}$ & \\
\hline $5 P$ & 16 Oct & 0600 & 15.1 & 1.0 & 0.00 & 0.0 & $\mathrm{~N}$ & \\
\hline $7 Y$ & 16 Oct & 0830 & 25.7 & 1.0 & 0.87 & 87.0 & $\mathrm{~N}$ & \\
\hline $10 P$ & 16 Oct & 1455 & 92.0 & 1.0 & 0.26 & 26.0 & $\mathrm{Y}$ & 22.0 \\
\hline $11 Y$ & 16 Oct & 2055 & 197.0 & 1.0 & 0.90 & 90.0 & $\mathrm{~N}$ & \\
\hline $12 \mathrm{E}$ & 17 Oct & 0130 & 215.5 & 1.0 & 0.00 & 0.0 & $\mathrm{~N}$ & \\
\hline $13 P$ & $17 \mathrm{Oct}$ & 0450 & 233.0 & 1.0 & 0.94 & 94.0 & Y & 50.0 \\
\hline \multicolumn{9}{|c|}{ 311-U1329C- } \\
\hline $7 P$ & $28 \mathrm{Sep}$ & 0255 & 55.6 & 1.0 & 1.00 & 100.0 & $Y$ & 0.0 \\
\hline $14 \mathrm{P}$ & $28 \mathrm{Sep}$ & 1110 & 114.6 & 1.0 & 1.00 & 100.0 & $\mathrm{~N}$ & \\
\hline $23 P$ & 29 Sep & 0210 & 188.5 & 1.0 & 1.00 & 100.0 & Y & 2.4 \\
\hline \multicolumn{9}{|c|}{ 311-U1329E- } \\
\hline $5 P$ & 1 Oct & 0630 & 33.5 & 1.0 & 0.00 & 0.0 & $\mathrm{~N}$ & \\
\hline $7 P$ & 1 Oct & 1220 & 73.5 & 1.0 & 0.86 & 86.0 & Y & 0.7 \\
\hline $8 Y$ & 1 Oct & 1430 & 104.0 & 1.0 & 1.00 & 100.0 & $\mathrm{~N}$ & \\
\hline $9 \mathrm{E}$ & 1 Oct & 1625 & 114.5 & 1.0 & 1.00 & 100.0 & Y & \\
\hline $10 \mathrm{P}$ & 1 Oct & 1940 & 125.0 & 1.0 & 0.95 & 95.0 & Y & 0.0 \\
\hline
\end{tabular}

Note: Core type: $\mathbf{P}=$ Pressure Core Sampler (PCS), $\mathrm{Y}=$ Fugro Percussion Corer (FPC), E = HYACE Rotary Corer (HRC). 
Table T4. Summary of all sediment core and pressure core gas hydrate samples taken during Expedition 311.

\begin{tabular}{|c|c|c|c|c|c|c|}
\hline $\begin{array}{l}\text { Core, section, } \\
\text { interval }(\mathrm{cm})\end{array}$ & $\begin{array}{l}\text { Sample } \\
\text { length } \\
(\mathrm{cm})\end{array}$ & $\begin{array}{l}\text { Sample } \\
\text { depth top } \\
\text { (mbsf) }\end{array}$ & $\begin{array}{l}\text { Temperature } \\
\text { anomaly }\end{array}$ & $\begin{array}{l}\text { Type of } \\
\text { sample }\end{array}$ & $\begin{array}{c}\text { Type of } \\
\text { preservation }\end{array}$ & $\begin{array}{l}\text { Laboratory } \\
\text { sample ID }\end{array}$ \\
\hline \multicolumn{7}{|c|}{ Sediment core samples } \\
\hline \multicolumn{7}{|l|}{ 311-U1326C- } \\
\hline $9 X-3,91-106$ & 15 & 73.01 & M & WRC & LN2 & HYD22 \\
\hline \multicolumn{7}{|l|}{ 311-U1326D- } \\
\hline $4 X-6,0-8$ & 8 & 114.57 & M & WRC & LN2 & HYD23 \\
\hline $5 X-5,36-56$ & 20 & 123.40 & M & WRC & LN2 & HYD24 \\
\hline $18 X-3,120-130$ & 10 & 245.81 & $\mathrm{H}$ & WRC & LN2 & HYD25 \\
\hline $18 X-3,130-140$ & 10 & 245.91 & $\mathrm{H}$ & WRC & LN2 & HYD26 \\
\hline $18 X-1,84-105$ & 21 & 243.44 & M & WRC & LN2 & HYD27 \\
\hline \multicolumn{7}{|l|}{ 311-U1327C- } \\
\hline $13 X-5,101-126$ & 25 & 109.11 & L & WRC & LN2 & HYD1 \\
\hline $17 X-1,20-31$ & 11 & 132.00 & $\mathrm{HH}$ & WRC & LN2 & HYD2 \\
\hline $18 X-2,10-20$ & 10 & 142.45 & $\mathrm{H}$ & WRC & LN2 & HYD3 \\
\hline $19 \mathrm{X}-1,101-121$ & 20 & 152.11 & $\mathrm{H}$ & WRC & LN2 & HYD4 \\
\hline $27 X-3,40-50$ & 10 & 221.69 & $\mathrm{H}$ & WRC & LN2 & HYD5 \\
\hline \multicolumn{7}{|l|}{ 311-U1327D- } \\
\hline $7 X-2,57-82$ & 25 & 135.07 & H & WRC & LN2 & HYD6 \\
\hline $11 X-1,24-48$ & 24 & 157.34 & $\mathrm{HH}$ & WRC & LN2 & HYD7 \\
\hline \multicolumn{7}{|l|}{ 311-U1328B- } \\
\hline $2 \mathrm{H}-1,5-10$ & 5 & 4.55 & NA & PS & LN2 & HYD8 \\
\hline $2 \mathrm{H}-1,10-15$ & 5 & 4.60 & NA & PS & LN2 & HYD9 \\
\hline $2 \mathrm{H}-1,15-20$ & 5 & 4.65 & NA & PS & LN2 & HYD10 \\
\hline $2 \mathrm{H}-1,20-40$ & 20 & 4.70 & NA & PS & LN2 & HYD11 \\
\hline $2 \mathrm{H}-1,40-60$ & 20 & 4.90 & NA & PS & LN2 & HYD12 \\
\hline $2 \mathrm{H}-1,60-80$ & 20 & 5.10 & NA & PS & LN2 & HYD13 \\
\hline $2 \mathrm{H}-\mathrm{CC}, 0-5$ & 5 & 6.12 & NA & PS & LN2 & HYDCC \\
\hline $5 \mathrm{H}-\mathrm{CC}, 5-10$ & 5 & 18.29 & NA & PS & LN2 & HYDCC \\
\hline $6 \mathrm{X}-\mathrm{CC}, 5-10$ & 5 & 21.06 & NA & PS & LN2 & HYDCC \\
\hline $8 \mathrm{H}$, rig floor & NA & 28.00 & NA & PS & LN2 & HYDCC \\
\hline \multicolumn{7}{|l|}{ 311-U1328D- } \\
\hline $2 X-2,59-79$ & 20 & 6.09 & $\mathrm{~L}$ & WRC & LN2 & HYD14 \\
\hline $2 \mathrm{X}-\mathrm{CC}, 5-9$ & 4 & 6.34 & NA & PS & LN2 & HYDCC \\
\hline \multicolumn{7}{|l|}{ 311-U1328E- } \\
\hline $2 \mathrm{X}-\mathrm{CC}, 0-10$ & 10 & 8.79 & NA & PS & LN2 & HYD15 \\
\hline $2 X-2,80-90$ & 10 & 8.69 & M & WRC & LN2 & HYD16 \\
\hline $2 X-2,70-80$ & 10 & 8.59 & M & WRC & LN2 & HYD17 \\
\hline $2 X-2,60-70$ & 10 & 8.49 & M & WRC & LN2 & HYD18 \\
\hline $2 X-2,50-60$ & 10 & 8.39 & M & WRC & LN2 & HYD19 \\
\hline $2 X-2,40-50$ & 10 & 8.29 & M & WRC & LN2 & HYD20 \\
\hline $2 X-2,20-40$ & 20 & 8.09 & M & WRC & LN2 & HYD21 \\
\hline \multicolumn{7}{|c|}{ Pressure core samples } \\
\hline \multicolumn{7}{|l|}{ 311-U1327D- } \\
\hline $14 \mathrm{E}-1,25-45$ & 20 & 217.70 & NA & WRC & PV & BHPAR22 \\
\hline $14 \mathrm{E}-1,45-65$ & 20 & 217.70 & NA & WRC & PV & BHPAR15 \\
\hline $14 \mathrm{E}-1,65-85$ & 20 & 217.70 & NA & WRC & PV & BHPAR13 \\
\hline $14 \mathrm{E}-1,85-105$ & 20 & 217.70 & NA & WRC & PV & BHPAR11 \\
\hline $12 \mathrm{E}-1,0-100$ & 105 & 170.50 & NA & WRC & PV & NA \\
\hline
\end{tabular}

Notes: Temperature anomaly scale: $\mathrm{L}=$ small, $\mathrm{M}=$ medium, $\mathrm{H}=$ large, $\mathrm{HH}=$ very large. Type of sample: $\mathrm{WRC}=$ whole-round core, $\mathrm{PS}=$ extruded pieces of gas hydrate with sediment. Type of preservation: $L N 2=$ liquid nitrogen, $P V=$ pressure vessel. ID = designation number. NA = not available. 